$\begin{array}{rrrrrr}\mathbf{R} & \mathbf{P} & \mathbf{A} & \mathbf{Y} \\ & & & \begin{array}{r}\text { Studia Źródłoznawcze, t. LVI } \\ \text { p-ISSN 0081-7147 } \\ \text { e-ISSN 2451-1331 }\end{array}\end{array}$

Hanna RAJFURA

Instytut Historyczny Uniwersytetu Warszawskiego

\title{
Warsztat pisarski Jana Długosza w świetle Żywotu św. Stanisława*
}

Zarys treści: Artykuł zawiera omówienie warsztatu pisarskiego Jana Długosza (1415-1480) na podstawie Żywotu $s ́$ w. Stanisława (lata 60. XV w.). Przedstawiony został literacki aspekt tego dzieła (topika hagiograficzna, retoryczne środki wyrazu, teoria trzech stylów, technika narracji, okresy retoryczne, proza rytmizowana). Zarysowano też stosunek Długosza do XIII-wiecznego Żywotu większego św. Stanisława.

\begin{abstract}
The article discusses literary skills of Jan Długosz (1415-1480) on the basis of Life of St. Stanislaus written in the 1460s. Author describes literary aspect of this work (literary topoi, rhetorical devices, theory of three styles, narrative technique, periodic sentences, prose rhythm), and Długosz's attitude towards the $13^{\text {th }}$-century Vita maior of st. Stanislaus.
\end{abstract}

Słowa kluczowe: Jan Długosz, Stanisław ze Szczepanowa, Wincenty z Kielc (Kielczy), hagiografia

Keywords: Jan Długosz, Stanislaus of Szczepanów, Wincenty of Kielce (Kielcza), hagiography

\section{Wstęp $^{1}$}

Przedmiotem studium jest Żywot św. Stanisława napisany przez Jana Długosza (1415-1480) w latach 60. XV w. ${ }^{2}$ Jest to jedno z dwu jego dzieł hagiograficznych, drugie - Żywot bł. Kingi - ukończył dekadę później³ . Długosz poświęcił żywoty postaciom szczególnie dla niego istotnym. Świętego Stanisława

* Artykuł powstał na podstawie pracy magisterskiej pt. „Żywot św. Stanisława” Jana Dlugosza na tle tradycji hagiograficznej, przygotowanej w 2017 r. w Instytucie Historycznym UW pod kierunkiem dr. hab. Piotra Węcowskiego. Zasadnicze tezy pracy były omawiane na seminarium doktorskim prof. dr hab. Marii Koczerskiej w IH UW oraz na zebraniu naukowym krakowskiego oddziału Polskiego Towarzystwa Heraldycznego. Wszystkim dyskutantom dziękuję za uwagi do wygłoszonego referatu.

${ }^{1}$ Dla zwięzłej i czytelnej prezentacji materiału w artykule zastosowano następujące skróty: Ann., nr księgi, strona (rok) J. Długosz, Annales seu Cronicae incliti Regni Poloniae, t. 1-11, Varsaviae-Cracoviae 1964-2005; BHL - Bibliotheca Hagiographica Latina antiquae et mediae aetatis, t. 1-2, Bruxellis 1898-1901; VMa - Vita sancti Stanislai Cracoviensis episcopi (Vita maior), wyd. W. Kętrzyński, w: MPH, t. 4, Lwów 1884, s. 319-438; VMi - Vita sancti Stanislai episcopi Cracoviensis (Vita minor), wyd. W. Kętrzyński, w: tamże, s. 238-285; VSt - J. Długosz, Vita sanctissimi Stanislai Cracoviensis episcopi, w: tenże, Opera, t. 1, wyd. I. Polkowski, Ż. Pauli, Cracoviae 1887, s. 1-181; Złota legenda - Jakub de Voragine, Złota legenda. Wybór, tłum. J. Pleziowa, wybór, wstęp i przyp. M. Plezia, Warszawa 1983; Życie św. Stanisława - J. Długosz, Życie świętego Stanisława biskupa krakowskiego, thum. S. Bełch, Londyn 1948; Żywot mniejszy - Żywot mniejszy św. Stanisława, w: Średniowieczne żywoty i cuda patronów Polski, thum. J. Pleziowa, oprac. i wstęp M. Plezia, Warszawa 1987, s. 97-150; Żywot większy - Żywot większy św. Stanisława, w: tamże, s. 235-344.

2 Nt. życia Długosza zob.: M. Bobrzyński, S. Smolka, Jan Długosz, jego życie i stanowisko w piśmiennictwie, Kraków 1893; M. Plezia, Jan Dlugosz, w: Pisarze staropolscy. Sylwetki, t. 1, red. S. Grzeszczuk, Warszawa 1991, s. 132-173.

${ }^{3}$ Por. M. Pajor, Wokół tradycji rękopiśmiennej „, Vita beatae Kunegundis” Jana Długosza, „Studenckie Zeszyty Historyczne Koła Naukowego Historyków Studentów UJ”, 21, 2014 (zeszyt okolicznościowy pt. Signa. Studia i szkice z nauk pomocniczych historii. Prace dedykowane profesorowi Zenonowi Piechowi w sześćdziesiąta rocznicę urodzin, red. A. Marzec, M. Starzyński), 
traktował z wyjątkowym nabożeństwem, czemu wielokrotnie dał wyraz w omawianym źródle, podobnie jak we wszystkich innych utworach oraz w pobożnych fundacjach ${ }^{4}$. Kult biskupa-męczennika potwierdził także autor żywotu dziejopisa ${ }^{5}$. Święty Stanisław, już jako postać legendarna, uosabiał bowiem wszystko, co było dla Długosza najistotniejsze: był patronem Królestwa Polskiego i Kościoła krakowskiego, niezłomnym hierarchą, który nie ugiął się pod królewskim naciskiem, rdzennie polskim męczennikiem i - co nie mniej ważne - krakowskim świętym urodzonym w Małopolsce (lokalny patriotyzm Długosza był bowiem bardzo rozwinięty ${ }^{6}$ ).

Święty Stanisław stał się także osią historiozoficznej myśli dziejopisa. Ten święty, jego konflikt z występnym królem Bolesławem i bestialska zbrodnia na biskupie miały zakończyć „złoty wiek” w dziejach państwa polskiego. Grzech władcy ściągnął Bożą pomstę na Bolesława, jego ród i całą Polskę, która z tego powodu utraciła status królestwa. Karą od Boga miało być także translatio regni odebranie władzy Piastom (według Długosza „panom naturalnym”) i przekazanie jej obcym dynastiom Andegawenów, a później Jagiellonów, określanym jako „przybysze” (peregrini). Zasadnicze rysy tej koncepcji Długosz zaczerpnął z XIII-wiecznych żywotów dominikanina Wincentego, a potem rozwinął i dostosował do realiów współczesnych sobie czasów. W Życiu św. Stanisława kanonik w pełni zaprezentował swoją myśl historiozoficzną. Obszernie opisał tło i przebieg konfliktu, portret biskupa rozbudował motywami hagiograficznymi, a całość ubarwił środkami stylistycznymi i wzmocnił retorycznymi amplifikacjami. By przedstawić swoją koncepcję, dokonał szeregu literackich zabiegów - i właśnie o tej „technicznej” stronie Żywotu traktują niniejsze rozważania.

Celem artykułu jest przedstawienie Żywotu św. Stanisława (BHL 7839) jako wytworu polskiej kultury późnego średniowiecza. Analiza tego źródła daje sposobność wniknięcia w warsztat pracy historyka oraz porównania go z jego metodą pracy nad Rocznikami i innymi, głównie inwentaryzacyjno-katalogowymi, dziełami. Poza tym dzięki Żywotowi możliwe jest zbadanie stosunku Długosza do konwencji hagiograficznej i jego inwencji w tym zakresie. Dotąd wielu badaczy marginalizowało znaczenie $\dot{Z} y w o t u$, ponieważ interesowała ich głównie rekonstrukcja XI-wiecznego zatargu biskupa i króla, do której praca Długosza, co oczywiste, nie mogła nic wnieść ze względu na późną metrykę. Ponadto, jako dzieło hagiograficzne, Żywot obciążony jest balastem konwencji pisarskiej, utrudniającej wydobycie prawdy historycznej spod topicznego sztafażu. Wziąwszy pod uwagę specyfikę utworów hagiograficznych, analizuję literacki aspekt Żywotu, a także zarysowuję sposób wykorzystania przez Długosza XIII-wiecznego Żywotu większego autorstwa dominikanina Wincentego. Zastosowanie literaturoznawczego kwestionariusza badawczego do tak dopracowanego utworu pozwala dokładniej opisać i ocenić warsztat pisarski Długoszaํ.

s. 119, który twierdzi, że Żywot bł. Kingi mógł powstać w latach 1461-1463; O.M. Przybyłowicz, , Vita beatae Kunegundis” $z$ archiwum klarysek $w$ Starym Sączu. Losy rękopisu, stan zachowania, źródła wiedzy kronikarza o klasztorze ubogich pań, w: Jan Dlugosz (1415-1480). Życie i dzieła, red. L. Korczak, M.D. Kowalski, P. Węcowski, Kraków 2016, s. 90, twierdzi, że „trudno przesądzić” o tym, czy Długosz zaczął pracę już w pierwszej połowie lat 60 . XV w.

${ }^{4}$ Np. VSt, s. 2: „neminem Sanctorum ratus, cui aliquando patria nostra, vel pro opere vel officio, vel pro vita et martyrio plus deberet"; o czci Długosza dla św. Stanisława świadczą m.in. fundacja i wyposażenie murowanego kościoła w Szczepanowie (J. Długosz, Liber beneficiorum dioecesis Cracoviensis, t. 2-3, Cracoviae 1864, t. 2, s. 268, 1470 r.) oraz fundacja klasztoru Paulinów w kościele pw. św. Michała Archanioła na Skałce (tamże, t. 3, s. 113-115, lata 1471-1472); U. Borkowska, Św. Stanisław w koncepcji narodowej Jana Dtugosza, „Znak”, 31, 1979, nr 298-299 (4-5), s. 344 n.

5 Vita Ioannis Dlugosch senioris canonici Cracoviensis, wyd. M. Brożek, Varsoviae 1961, s. 37: „,um inter praecipuos advocatos in adversitatibus suis haberet sanctum Stanislaum et pro comperto crederet multas insidias per illius intercessionem ac merita evasisse, volens, quantum in eo erat, sanctissimo martyri gratiam rependere"; o atrybucji żywotu Długosza Jakubowi z Szadka zob. M. Koczerska, Kto jest autorem „Żywotu Dtugosza”?, w: Venerabiles, nobiles et honesti. Studia z dziejów społeczeństwa Polski średniowiecznej. Prace ofiarowane profesorowi Januszowi Bieniakowi w siedemdziesiata rocznice urodzin i czterdziestopięciolecie pracy naukowej, red. A. Radzimiński, A. Supruniuk, J. Wroniszewski, Toruń 1997, s. 507-520.

${ }^{6}$ M. Koczerska, Mentalność Jana Dlugosza w świetle jego twórczości, St. Źródł., 15, 1970, s. 130; P. Węcowski, Historical Memory and Local Identity. Jan Dlugosz and the Church in Cracow [w druku].

${ }^{7}$ O wysmakowanym języku Długoszowego Żywotu św. Stanisława świadczyć mogą słowa I. Polkowskiego, Katalog rękopisów kapitulnych katedry krakowskiej, w: Archiwum do dziejów literatury i oświaty w Polsce, t. 3, Kraków 1884, s. 134: „gdybyśmy nie mieli dowodów przekonywujących iż Długosz napisał żywot św. Stanisława, to znając styl jego, zachowany jednostajnie w Historyi i w Liber Beneficiorum, niktby nie poznał, iż to dzieło historyka naszego". 
W badaniu wykorzystuję w głównej mierze żywotową część dzieła (tractatus I). Pomijam kwestię ewentualnej recepcji przez Długosza XIV-wiecznego żywotu św. Stanisława Tradunt (BHL 7836), który wciąż wymaga podstawowych badań ${ }^{8}$. Nie zajmuję się też zależnością między Żywotem kanonika a jego Rocznikami i Katalogiem biskupów krakowskich, za istotę pracy uznając analizę samego Żywotu i przedstawienie warsztatu pisarskiego Długosza-hagiografa.

W pracy wykorzystałam XIX-wieczne wydanie łacińskiego tekstu Żywotu przygotowane przez Ignacego Polkowskiego i Żegotę Pauliego ${ }^{9}$. Z tej edycji pochodzą przytaczane w artykule łacińskie cytaty z $\dot{Z}$ ywotu. W wybranych miejscach opatrzyłam je polskimi przekładami zaczerpniętymi z XX-wiecznego tłumaczenia Stanisława Bełcha ${ }^{10}$, powstałego z kolei na podstawie przekładu Ludwika Feliksa Karczewskiego z drugiej połowy XIX w. ${ }^{11}$ Polskojęzyczne cytaty podaję $\mathrm{w}$ formie minimalnie zmodernizowanej w stosunku do thumaczenia z 1948 r.: stosuję zgodną z dzisiejszymi zasadami pisownię łączną i rozdzielną, użycie wielkich i małych liter oraz interpunkcję, koryguję również tzw. chochliki drukarskie.

Żywot św. Stanisława, patrona Kościoła krakowskiego i Królestwa Polskiego, napisany przez Jana Długosza nie doczekał się dotąd - co zaskakujące - własnego, pełnego opracowania. Często wzmiankuje się to dzieło podczas omawiania wyobrażeń na temat konfliktu biskupa z Bolesławem Śmiałym czy rozwoju kultu św. Stanisława, niestety zwykle poprzestając na parafrazie treści ok. 200-stronicowego (licząc objętość rękopiśmienną) dzieła. Powstało jednak kilka prac, w których temu źródłu poświęcono więcej uwagi. Krytyczne rozbiory Żywotu opracowali Kazimierz Krotoski ${ }^{12}$ i Marian Plezia $^{13}$. Wskazali oni liczne źródła, z których dziejopis zaczerpnął wiedzę na temat św. Stanisława: Kronikę Galla Anonima, Kronikę Wincentego Kadłubka, różne redakcje Katalogu biskupów krakowskich, Kronikę śląsko-polska, Kronikę wielkopolska, Rocznik mansjonarzy krakowskich (tzw. Rocznik świętokrzyski nowy) oraz Komentarz Jana Dąbrówki do Kroniki Kadłubka. O ile K. Krotoski potraktował Żywot protekcjonalnie, wytykając dziejopisowi rozmaite dodatki, ale nie starając się wniknąć w ich głębszy sens ${ }^{14}$, o tyle M. Plezia powiązał treść dzieła z jego moralizatorsko-ludycznym przeznaczeniem i tak wytłumaczył jego szczegółowość, anegdotyczność oraz retoryczność. W sprawie czasu powstania Żywotu głos zabrał Mieczysław Brożek, popierając utarty w nauce pogląd, że zasadniczą część dzieła Długosz napisał w okresie sporu o biskupstwo krakowskie (1460-1463), podczas ponadrocznego pobytu w dobrach Tęczyńskich i Melsztyńskich ${ }^{15}$. Od filologicznej strony Żywot św. Stanisława (wraz z Długoszowym Żywotem bł. Kingi ${ }^{16}$ ) zbadała Danuta Turkowska, opisując składniowe, frazeologiczne, leksykalne i stylistyczne predylekcje dziejopisa ${ }^{17}$. Dla niniejszej pracy istotne jest, że krakowska badaczka zwróciła uwagę na środki stylistyczne wykorzystane przez Długosza. Wyniki jej badań spożytkowałam podczas opisu figur słów zastosowanych w Żywocie, uzupełniając je o charakterystykę obecnych w dziele figur myśli. Aleksandra Witkowska omówiła XV-wieczne miracula, które Długosz dołączył

${ }^{8}$ Nie sporządzono do tej pory krytycznego wydania tego żywotu. Jedyna istniejąca edycja pochodzi z pierwszej połowy XIX w. - nie spełnia ona dzisiejszych wymogów edytorskich, zresztą wydania tego dokonano z jednej i to późnej kopii, podczas gdy dziś znane są cztery; Martini Galli Chronicon ad fidem codicum, wyd. J.V. Bandtkie, Varsoviae 1824, s. 321-380; zob. P. Węcowski, Początki Polski w pamięci historycznej późnego średniowiecza, Kraków 2014, s. 88-91.

9 VSt, s. 1-181.

10 Życie św. Stanistawa.

11 J. Długosz, Żywot Świętego Stanisława, biskupa krakowskiego, oraz żywoty świętych patronów polskich, wegierskich, czeskiech, morawskich, pruskich i szlązkich nie umieszczone w Historyi Lombardzkiej, tłum. L.F. Karczewski, Kraków 1865.

${ }^{12}$ K. Krotoski, Ś. Stanisław biskup w świetle źródet. Rozbiór krytyczny źródet odnoszacych się do kwestyi Ś. Stanisława bisk., Kraków 1902, s. 76-104.

13 M. Plezia, Dookoła sprawy św. Stanisława. Studium źródłoznawcze, „Analecta Cracoviensia”, 11, 1979, s. 251-413, zwł. s. $369-380$

${ }^{14}$ K. Krotoski, Ś. Stanisław biskup, np. s. 87: „te i tym podobne dodatki chwytają na gorącym uczynku przędzę bajeczną podania i wykazują jej nicość".

15 M. Brożek, Przyczynki do łacińskiego żywotopisarstwa w Polsce, w: Księga pamiątkowa ku czci Stanisława Pigonia, red. Z. Czerny, H. Markiewicz, J. Nowakowski i in., Kraków 1961, s. 133-142, zwł. s. 138-142.

${ }^{16}$ Leksykę tego drugiego Żywotu scharakteryzował J. Wojtczak-Szyszkowski, „Żywot świętej Kingi” Jana Dlugosza. Studia nad językiem i stylem, Paprotnia 2004.

17 D. Turkowska, Etudes sur la langue et sur le style de Jean Dlugosz, Kraków 1973. 
do $\dot{Z} y w o t u^{18}$. Na podstawie zachowanych informacji określiła ona charakter kultu św. Stanisława na Wawelu i na Skałce oraz - porównując go z innymi lokalnymi XV-wiecznymi kultami - przedstawiła na tle religijno-pielgrzymkowej panoramy Krakowa i Małopolski. Wśród prac ogólnikowo tylko wspominających Żywot św. Stanisława znajdują się przede wszystkim syntezy ${ }^{19}$. Zaledwie wzmiankę na temat tego dzieła zamieszczono w pracy Michała Bobrzyńskiego i Stanisława Smolki ${ }^{20}$ oraz w artykułach Jerzego Starnawskiego $^{21}$. Także obszerna publikacja Stanisława Bełcha, ze względu na konfesyjny charakter, nie przyczyniła się do dokładniejszego rozbioru Żywotu Długosza ${ }^{22}$. Żywot św. Stanisława bywał także wykorzystywany jako źródło w badaniach nad umysłowością Długosza i jego współczesnych. Maria Koczerska zużytkowała go do zbadania światopoglądu i mentalności dziejopisaa ${ }^{23}$, a Sławomir Gawlas do charakterystyki jego świadomości narodowej ${ }^{24}$. Urszula Borkowska wyzyskała zawarte tam informacje na temat portretów monarchy i ordynariusza w twórczości Długosza oraz zależności między władzą duchowną a świecką, opisała także historiozoficzną myśl dziejopisa i jego przekonania na temat zmiany dynastii w Polsce ${ }^{25}$. O politycznym przekazie dzieł hagiograficznych (w tym i Żywotu Długosza) pisał Dariusz Rychlewicz ${ }^{26}$. W ostatnich latach Piotr Węcowski, m.in. na podstawie Żywotu, scharakteryzował stosunek późnośredniowiecznych polskich pisarzy do faktu utraty korony królewskiej ${ }^{27}$, a Wojciech Drelicharz posłużył się Żywotem, prowadząc badania nad ideą zjednoczenia Królestwa Polskiego ${ }^{28}$.

Tytułowy Żywot znany jest z rękopisu sygn. 214 (nr 202 według numeracji I. Polkowskiego) przechowywanego w Archiwum Krakowskiej Kapituły Katedralnej ${ }^{29}$. Jest to kodeks pergaminowy o wymiarach 285 x 195 mm, złożony ze 110 kart. Oprawa w postaci drewnianej deski obciągniętej aksamitem pochodzi z czasów nowożytnych. Tekst spisano starannym pismem. Jest to praca jednej wyrobionej ręki z końca XV w. D. Turkowska suponuje, że to pismo Krzysztofa z Dębowca (Dębowdziału) koło Jasła, osobistego notariusza Długosza (od co najmniej 1467 r.) i kopisty jego Żywotu bt. Kingi ${ }^{30}$.

${ }^{18}$ A. Witkowska, Kulty pątnicze piętnastowiecznego Krakowa. Z badań nad miejska kultura religijna, Lublin 1984, s. 82-87.

${ }^{19}$ H. Zeissberg, Dziejopisarstwo polskie wieków średnich, t. 2, Warszawa 1877, s. 91-94; J. Dąbrowski, Dawne dziejopisarstwo polskie (do roku 1480), Wrocław 1964, s. 211 n.; T. Michałowska, Średniowiecze, Warszawa 2008, s. 769; taż, Literatura polskiego średniowiecza. Leksykon, Warszawa 2011, s. 379-380; T. Dunin-Wąsowicz, Hagiographie polonaise entre XI et $X V I^{e}$ siècle, w: Hagiographies. Histoire internationale de la littérature hagiographique latine et vernaculaire en Occident des origines à 1550, red. G. Philippart, Turnhout 2001, s. 179-202, zwł. s. 189, 194 n.

${ }_{20}$ M. Bobrzyński, S. Smolka, Jan Dlugosz, s. 206.

21 J. Starnawski, Drogi rozwojowe hagiografii polskiej i łacińskiej w wiekach średnich, Kraków 1993, s. 96-105; tenże, Drogi rozwojowe hagiografii średniowiecznej w Polsce, w: Nurt religijny $w$ literaturze polskiego średniowiecza i renesansu, red. S. Nieznanowski, J. Pelc, Lublin 1994, s. 11-41, o Żywocie na s. 35-37.

22 S. Bełch, Święty Stanisław: biskup-męczennik, patron Polaków, London 1977.

${ }_{23}$ M. Koczerska, Mentalność Jana Dlugosza, s. 109-140.

${ }^{24}$ S. Gawlas, Świadomość narodowa Jana Dlugosza, St. Źródł., 27, 1983, s. 3-66.

${ }^{25}$ U. Borkowska, Św. Stanisław w koncepcji narodowej, s. 344-351; taż, Historiograficzne poglady Jana Dtugosza, w: Dlugossiana. Studia historyczne w pięćsetlecie śmierci Jana Dlugosza, cz. 2: Referaty i komunikaty wygłoszone na międzynarodowej sesji w Krakowie w dniach 23 i 24 października 1980 r., red. S. Gawęda, Kraków 1985, s. 45-71; taż, Regnum i sacerdotium w pismach Jana Dlugosza, St. Źródł., 26, 1981, s. 3-21; taż, Treści ideowe w dziełach Jana Dlugosza. Kościót i świat poza Kościołem, Lublin 1983.

26 D. Rychlewicz, L'hagiographie polonaise au Moyen Âge et la propagande politique, w: La rôle des médias à travers l'histoire. Actes du VIII Colloque Poznań-Strasbourg 12-14 mai 1994, red. M. Serwański, Poznań 1995, s. 49-60, o Żywocie na s. 57 n.

${ }^{27}$ P. Węcowski, Strata korony królewskiej po śmierci św. Stanisława w opinii pisarzy późnego średniowiecza, w: Christianitas Romana. Studia ofiarowane Profesorowi Romanowi Michałowskiemu, red. K. Skwierczyński, Warszawa 2009, s. 274-299, Zwł. s. 291-294, 299.

28 W. Drelicharz, Idea zjednoczenia królestwa w średniowiecznym dziejopisarstwie polskim, Kraków 2012, s. 436-444.

${ }^{29}$ Opis przekazu na podstawie: I. Polkowski, Katalog rękopisów kapitulnych, s. 133-134, nr 202; I. Polkowski, Ż. Pauli, Praefatio, w: J. Długosz, Opera, t. 1, s. XIII-XIV; D. Turkowska, Etudes, s. 14-15.

${ }^{30}$ Przepisane przezeń rękopisy Żywotu bt. Kingi znajdują się w BCzart. (sygn. 1259, powst. 1475) i Archiwum klasztoru Klarysek w Starym Sączu (sygn. BK 1/AKKl.Sąd. rkps 3, powst. 1473). M. Kowalczyk, Pisarze „Annales” Jana Dtugosza, „Biuletyn Biblioteki Jagiellońskiej”, 49, 1999, nr 1-2, s. 103-109; M. Koczerska, Familiares Jana Dtugosza, w: Aetas media, aetas moderna. Studia ofiarowane Henrykowi Samsonowiczowi w siedemdziesiąta rocznicę urodzin, red. H. Manikowska, A. Bartoszewicz, W. Fałkowski, Warszawa 2000, s. 69-78; M. Pajor, Wokół tradycji rękopiśmiennej, s. 120-129; O.M. Przybyłowicz, ,, Vita beatae Kunegundis”, s. 87-101. 
Ta badaczka stwierdziła też, że tekst Żywotu św. Stanisława został ostatecznie skorygowany przez dziejopisa. Z XVI w. pochodzi paginacja rękopisu, jak również podział na rozdziały, którym nadano numery i tytuły.

\section{Żywot św. Stanisława Jana Długosza jako dzieło literackie}

Hagiografia jest gatunkiem silnie skonwencjonalizowanym, mającym dodatkowo cechować się literackimi walorami, dlatego analizując Żywot św. Stanisława, należy skupić się na jego formie. Utwór otwiera list dedykacyjny Długosza do Sędziwoja z Czechla. Żywot złożony jest z trzech części, z których każda opatrzona jest własnym prologiem ${ }^{31}$. W wydaniu te partie tekstu zostały nazwane tractatus ('traktat, rozprawa') ${ }^{32}$. Tractatus I w trzynastu rozdziałach zawiera opis życia i męczeńskiej śmierci św. Stanisława, cud zrośnięcia się ciała biskupa oraz dzieje Bolesława Śmiałego i Polski po 1079 r. Tractatus II w siedmiu rozdziałach mieści relacje o ukazywaniu się św. Stanisława, translacji jego ciała ze Skałki na Wawel i cudów, przez które męczennik miał domagać się kanonizacji. W ostatniej części dzieła - tractatus III - w sześciu rozdziałach Długosz opisał przebieg kanonizacji św. Stanisława i cuda, które później nastąpiły (do 1464 r. włącznie). Potem następuje list Sędziwoja do Długosza (nazwany przez wydawców rozdz. 7) oraz część o cudach, które za wstawiennictwem biskupa-męczennika zdarzyły się w latach 70. XV w. (wedle wydania rozdz. 8). Pomijając kwestię wtórności podziału na tractatus i capitula, w kompozycji Żywotu widać zastosowanie typowej trójdzielnej konstrukcji żywotu (przebieg życia, kanonizacja i cuda), obecnej także chociażby w Żywocie większym św. Stanisława pióra dominikanina Wincentego, choć z nieco innym podziałem materiału na poszczególne części ${ }^{33}$.

Długoszowy Żywot można podzielić w inny sposób, biorąc pod uwagę retoryczną stronę dzieła. Swego czasu zauważono, że perswazyjny i moralizujący cel hagiografii najlepiej wspierały środki retoryczne znane z klasycznych mów pochwalnych. Idąc tym tropem, można wykazać, że żywoty świętych - podobnie jak oracje - zawierają prolog, część narracyjną, część argumentacyjną i epilog ${ }^{34}$. Ta obserwacja stosuje się także do dzieła Długosza.

\section{Prologus}

Prolog (prologus, prooemium, exordium) służy uprzedzeniu odbiorcy o temacie utworu i jego celu ${ }^{35}$; w przypadku żywotu jest to wskazanie moralnego ideału oraz wezwanie do podziwiania i naśladowania go. Wstępy składają się zazwyczaj ze ściśle określonych elementów ${ }^{36}$ - list dedykacyjny i prolog do Żywotu św. Stanisława zawierają je wszystkie, świadcząc o wprawie pisarskiej autora.

${ }^{31}$ Gall Anonim dołączył oddzielny wstęp do każdej z ksiąg Kroniki, za to Wincenty Kadłubek zamieścił w Kronice jeden ogólny prolog i jeden prolog poprzedzający niedialogową część utworu. Te prace stanowiły punkt odniesienia dla wszystkich późniejszych polskich pisarzy średniowiecznych; zob. P. Bering, Struktury narracyjne w późnośredniowiecznych łacińskich kronikach regionalnych, Gniezno 2001, s. 88.

32 Podział dzieła na tractatus i capitula wprowadzono w edycji Żywotu wyd. przez Jana Hallera w Krakowie w 1511 r. W pracy dla ułatwienia lokalizacji miejsc w tekście używam określeń tractatus I/II/III, z pełną świadomością ich wtórnego pochodzenia.

33 A. Witkowska, Miracula małopolskie z XIII i XIV wieku. Studium źródloznawcze, Rocz. Hum., 19, 1971, nr 2, s. 92; por. W. Jurow, Praktyka pisarska i literackie tradycje żywotów świętych polskich do końca wieku XVI, Przegl. Hum., 14, 1970, nr 6, s. 122. Budowa Żywotu większego: prolog; część 1 (14 rozdziałów): tło historyczne, pochodzenie i młodość Stanisława, początek pontyfikatu; część 2 (27 rozdziałów): cud piotrawiński, kontynuacja tła historycznego, okrutne rządy Bolesława, męczeństwo biskupa, pierwsze cuda, utrata korony przez Polskę i szansa na jej odzyskanie; część 3 (57 rozdziałów): translacja ciała Stanisława, cuda, przez które męczennik domagał się kanonizacji, miracula zaprotokołowane przez pierwszą i drugą komisję kanonizacyjną, wyniesienie Stanisława na ołtarze.

${ }^{34}$ P. Nehring, Topika wczesnych łacińskich żywotów świętych (od „Vita Antonii” do „Vita Augustini”), Toruń 1999.

${ }_{35}$ Tamże, s. 16-32; H. Lausberg, Retoryka literacka. Podstawy wiedzy o literaturze, thum., oprac. i wstęp A. Gorzkowski, Bydgoszcz 2002, s. 157-174.

36 T. Janson, Latin Prose Prefaces. Studies in Literary Conventions, Stockholm-Göteborg-Uppsala 1964, s. 13, 66 n., 158; P. Bering, Struktury narracyjne, s. 97. 
W tej części dzieła Długosz wyłożył (1) powody jego napisania. Z jednej strony był to jego własny zamiar, z drugiej zaś praca miała powstać za sprawą prośby, a nawet żądania „mężów znakomitych” (viri illustres), którzy domagali się od kanonika napisania żywotu św. Stanisława ${ }^{37}$. Owo żądanie jest stałym elementem topiki eksordialnej i nie musi mieć związku z rzeczywistymi powodami powstania dzieła; również relacje między autorem dzieła a jego adresatem nie wpływały na postać tego toposu ${ }^{38}$. W przypadku Żywotu można domniemywać, że motywację pobudzało poczucie patriotycznego obowiązku, a także zamiar oddania czci św. Stanisławowi i zjednania mu kolejnych wiernych ${ }^{39}$. Innym typowym elementem prologu jest (2) podkreślenie wagi podjętego tematu i związanej z tym (3) własnej niemocy pisarskiej ${ }^{40}$. Długosz zastosował tu topos skromności, wykorzystywany już w dziełach autorów klasycznych i dodatkowo podkreślający humilitas chrześcijańskiego pisarza ${ }^{41}$. Także prośba, by adresat Żywotu poprawił go, a nawet zrzucenie na Sędziwoja odpowiedzialności za całą pracę, jest znanym od starożytności toposem ${ }^{42}$. Elementem konwencji jest (4) opis przeciwności, które autor musiał pokonać dla opracowania dzieła: poza brakiem talentu Długosz wymienił podeszły wiek i tempestates tum publicas tum privatas, czyli wydarzenia związane z jego zaangażowaniem w spór o obsadę biskupstwa krakowskiego (1460-1463) ${ }^{43}$. Oprócz tego w prologu kanonik zastosował zabieg (5) deminutio, podkreślający niemożność perfekcyjnego opisania dziejów św. Stanisława ${ }^{44}$.

Nie zabrakło w części wstępnej elementu (6) captatio benevolentiae, służącego pozyskaniu życzliwości odbiorcy. Chwaląc Stanisława ze Szczepanowa, Długosz skomplementował jednocześnie Sędziwoja, podkreślając jego podobieństwo do świętego ${ }^{45}$. Poza tym historyk wielokrotnie zaznaczał swoje przywiązanie do Sędziwoja, jego pobożność, wykształcenie oraz zdolności literackie - tymi ostatnimi cechami dziejopis uzasadniał prośbę o zaopiniowanie, a nawet korektę $\dot{Z} y w o t u^{46}$.

Prolog i list dedykacyjny to fragmenty, w których Długosz usiłował wzbudzić wiarygodność w odbiorcach dzieła. Zapewnił o (7) pilnym i szczegółowym zbadaniu losów św. Stanisława, wykazując jednocześnie znajomość wcześniejszych dzieł mu poświęconych. Nie wymienił jednak expressis verbis prac dominikanina Wincentego, które z pewnością znał (zob. niżej). Jako swoje wzory podał za to starsze, kanoniczne utwory hagiograficzne: żywoty św. Pawła pustelnika (BHL 6596), św. Hilariona (BHL nr 3879) i św. Pauli (BHL nr 6548) pióra Hieronima ze Strydonu (IV-V w.), żywot św. Marcina z Tours (BHL nr 5610) autorstwa Sulpicjusza Sewera (IV-V w.) oraz żywot św. Mikołaja (BHL nr 6128) w opracowaniu Symeona Metafrastesa (IX-X w.) i łacińskim przekładzie Leonarda z Wenecji (XIV-XV w.) ${ }^{47}$. Ta praktyka wpisuje się w konwencję imiennego przywoływania dawnych,

37 VSt, s. 5: „si tanta foret mihi styli virtus, et ea scribendi facultas infusa a Superis, seu natura comparata vel arte, quantus scribendi ardor”; tamże, s. 1: ,subierat diebus superioribus animum, Venerande Pater, idque frequenter pene assidua meditatione pectus decoquebat, et ingentem scribendi ingerebat pruritum”; tamże, s. 6: „non ex meo arbitratu et ingenio, sed ex praecipientium auctoritate".

38 T. Janson, Latin Prose Prefaces, s. 117-120; P. Nehring, Topika, s. 23 n.; por. Sulpicjusz Sewer, Żywot św. Marcina, w: tenże, Pisma ósw. Marcinie z Tours. Żywot, listy, dialogi, tłum. P.J. Nowak, wstęp, koment. i oprac. M. Starowieyski, posł. H. Malewska, Kraków 2012, s. 53; por. K. Krotoski, Ś. Stanisław biskup, s. 79, który owo „żądanie” przyjmuje dosłownie i przypisuje je Jakubowi z Sienna.

$39 V S t$, s. 6: „sed ut in Sanctum devotionem depromam, et in patriam, cui me omnia debere non inficior, demonstrem caritatem”.

40 VSt, s. 2: „neminem Sanctorum ratus, cui aliquando patria nostra, vel pro opere vel officio, vel pro vita et martyrio plus deberet".

${ }^{41}$ P. Nehring, Topika, s. 22.

42 T. Janson, Latin Prose Prefaces, s. 124, 141, 158.

${ }^{43}$ VSt, s. $1 \mathrm{n}$.

$44 V S t$, s. 2: „eius martyrii dignitas multo maior sit, quam vel a me describi, vel ingenio meo comprehendi possit”.

$45 \mathrm{VSt}$, s. 3: „et Sancto, quo de nunc agimus, propensiorem cultum exhibeas, et aliquid cum illo habeas commune, gestorum quoque illius et vitae aemulator existas".

46 VSt, s. 2-4.

47 W dalszej części pracy odwołuję się do przekładów: św. Hieronim, Żywoty mnichów Pawła, Hilariona, Malchusa, tłum., wstęp i oprac. B. Degórski, Kraków 1995; Hieronim ze Strydonu, List 108 do Eustochium dziewicy. Epitafium matki Pauli, w: tenże, Listy III (80-115), oprac. M. Ożóg, H. Pietras, Kraków 2011, s. 159-188; Sulpicjusz Sewer, Żywot św. Marcina. 
słynnych dzieł oraz unikania wzmianek o pracach bliższych czasom autora ${ }^{48}$. Kanonik zasugerował też (8) prawdziwość tego, co opisał, przez podanie informacji o wykorzystanych źródłach - tradycji pisemnej i ustnej ${ }^{49}$. Zastosował się przy tym do konwencjonalnej zasady brevitas, zapewniając, że opisał tylko to, co było konieczne, aby nie zanudzić czytelników (quantum opus est) ${ }^{50}$, a zarazem opuszczał tylko to, co nie należy do tematu (praeteritio) ${ }^{51}$.

Ciekawe są spostrzeżenia dziejopisa na temat statusu jego dzieła i opinii o utworach hagiograficznych. Sam nazwał swój żywot skromnie aliqua adiectionis materia i wprost stwierdził, że ma on być jedynie zachętą do pisania kolejnych żywotów przez osoby lepiej do tego przygotowane, a dokładniej przez profesorów Uniwersytetu Krakowskiego ${ }^{52}$. Długosz dzielił ze swoimi współczesnymi przekonanie, że każde nowo powstające dzieło hagiograficzne ma wartość większą od poprzednich prac, ponieważ pokazuje losy świętego w pełniejszy i piękniejszy sposób ${ }^{53}$. Ponadto artystyczna forma żywotu pozwalała autorowi wywrzeć większy wpływ na odbiorców i zachęcić ich do podziwiania oraz naśladowania przedstawionego ideału ${ }^{54}$. Ta deklaracja Długosza we wstępie do żywotu uzasadnia liczne amplifikacje, których dziejopis dokonał wobec Żywotu większego, chcąc całościowo i możliwie kunsztownie przedstawić życie swojego patrona.

\section{Narratio}

W mowach część zwana narratio służy przedstawieniu zdarzenia, którego dotyczy sprawa, za to $\mathrm{w}$ dziele hagiograficznym jest to opis życia i śmierci świętego ${ }^{55}$. Wedle prawideł retoryki ten fragment tekstu powinien być krótki (brevis), przejrzysty (perspicuus) i prawdopodobny (probabilis) - nie stanowi on bowiem istoty mowy, ale jest fundamentem dla późniejszej, argumentacyjnej części dzieła, w której orator przeprowadza dowodzenie i przekonuje odbiorców do swojego stanowiska (w hagiografii argumentatio przybiera nieco inną postać niż w retoryce; zob. niżej).

W Żywocie św. Stanisława część narracyjna wypełnia cały tractatus I, chronologicznie przedstawiając losy św. Stanisława od narodzin do śmierci. Kluczowe wydarzenia Długosz opatrzył datami (ewentualnie datował je względnie): (1) narodziny św. Stanisława (26 VII 1030), (2) śmierć biskupa Lamberta (25 XI 1071 $11^{56}$ ) i (3) elekcja św. Stanisława na jego następcę (2 II 1072), (4) śmierć św. Stanisława ${ }^{57}$, (5) translacja ciała św. Stanisława ze Skałki na Wawel (27 IX 1088), (6) prace komisji kanonizacyjnej (1250) oraz (7) kanonizacja św. Stanisława (1253). W hagiografii bezwzględne określenia czasowe należały do rzadkości, w razie konieczności stosowano nieprecyzyjne określenia względne (postea, mox itp. $)^{58}$. Najczęściej upływ czasu w narracji żywotopisarskiej odnotować można dzięki występującym

48 M. Plezia, Wstęp, w: Ztota legenda, s. 38.

49 VSt, s. 6: „quos vel de ipsius historiis vel de aliorum relatione indicatos cognovi”.

${ }^{50}$ Por. Hieronim ze Strydonu, Żywot św. Hilariona 15 (s. 142), 30 (s. 165 n.); Sulpicjusz Sewer, Żywot św. Marcina 1 (s. 57).

${ }_{51}$ P. Nehring, Topika, s. 47.

52 VSt, s. 6. Podobne wezwanie zamieścił Długosz w prologu do Roczników oraz w zamykającym je epilogu, prosząc nawet o stworzenie oddzielnej kolegiatury dla osoby, która kontynuowałaby jego pracę; Ann., ks. 1, s. 63 (list ded.) oraz ks. 12, s. 447 (1480 r.); por. hipoteza U. Borkowskiej (taż, Historiograficzne poglądy, s. 52, 60 n.), że Długosz mógł mieć nadzieję, iż jego Żywot stanie się lekturą uniwersytecką w ramach zajęć z retoryki.

53 VSt, s. 7: ,erit fortasse et non inamoenum, altero scemate Sancti explicare vitam, ut varietate tegminis, speciem laetiorem intuentibus praeseferat".

${ }^{54}$ Tamże: „vita enim Sancti quo plenius disertiusque describitur, tanto magis in pectoribus legentium et audientium dulcoratur, et animos mortalium superni muneris suavitate reficit et oblectat".

${ }_{55}$ P. Nehring, Topika, s. 33-62; H. Lausberg, Retoryka literacka, s. 175-206.

${ }_{56}$ Data pochodzi z III redakcji Katalogu biskupów krakowskich; Katalogi biskupów krakowskich, wyd. J. Szymański, w: MPH s.n., t. 10, cz. 2, Warszawa 1974, s. 44; K. Krotoski, Ś. Stanisław biskup, s. 84.

57 VSt, s. 62: „tertio Idus Maii, in quintam tunc cadente feriam”; tamże, s. 68 n.: „sub Gregorio Papa septimo, dum annum prope quinquagesimum ageret, [...] octo annis pontificali in Cracoviensi Ecclesia administrato sacerdotio"; S. Bełch za L.F. Karczewskim błędnie thumaczy „dnia ósmego maja” zamiast „dnia 13 maja”; zob. J. Długosz, Żywot świętego Stanistawa biskupa krakowskiego, s. 97; Życie św. Stanisława, s. 72, 79.

58 P. Nehring, Topika, s. 45. 
w niej osobom i zdarzeniom. Określenia czasowe częściej stosowano w legendach o biskupach, którzy prowadzili aktywne życie, niż w niemal „,bezczasowych” opowieściach o pustelnikach. Na tym tle pojawienie się aż siedmiu określeń czasu w Żywocie św. Stanisława jest nietypowym zjawiskiem, które należy przypisać historycznym zainteresowaniom jego autora ${ }^{59}$. Jako że kanonik znał przekazy informujące o niektórych wydarzeniach z życia biskupa-męczennika, włączył je do narracji o jego losach dla wzbogacenia utworu i rozpowszechnienia tej wiedzy wśród odbiorców. Mógł też wzorować się w tym względzie na Żywocie większym dominikanina Wincentego, w którym również pojawia się stosunkowo dużo dat ${ }^{60}$. Wprowadzenie dat rocznych podkreślało chronologiczny układ dzieła i czyniło kompozycję żywotu bardziej przejrzystą, tym samym realizując drugą z trzech zasad dobrze przygotowanej narratio.

Ostatni z tych warunków - prawdopodobieństwo - hagiograf spełniał, sytuując akcję żywotu w czasach, w których sam żył ${ }^{61}$. Zachowywał w dziele daty opisanych zdarzeń, ale wzbogacał narrację o szczegóły i wątki właściwe jego epoce. Metodę tę zastosował dominikanin Wincenty, pisząc np. o paryskich studiach św. Stanisława oraz biskupich wizytacjach parafii ${ }^{62}$. Podobnie materię pisarską potraktował Długosz - m.in. dlatego opisał, jak przyszły męczennik uczęszczał do gnieźnieńskiej szkoły katedralnej i podkreślał rolę kaznodziejstwa wśród duszpasterskich obowiązków duchownego.

W omawianym dziele, a zwłaszcza w jego biograficznej części, widać silny wpływ konwencji hagiograficznej. W Długoszowym żywocie znaleźć można bowiem wiele motywów występujących także we wcześniejszych żywotach, np. wspomnianych przez kanonika pracach Hieronima ze Strydonu i Sulpicjusza Sewera czy w Ztotej legendzie Jakuba de Voragine (XIII w.). Poniższa charakterystyka narracyjnej części Żywotu służy uwypukleniu jej topiczności przez wykazanie jej związków z wyżej wymienionymi pracami hagiograficznymi. Gros tych motywów nie pojawia się w XIII-wiecznych Żywotach, a zatem jest oryginalnym wkładem Długosza w rozwój legendy o św. Stanisławie ${ }^{63}$.

Typowa legenda powinna rozpoczynać się od opisu narodzin i młodości świętego - i w Żywocie $s ́$ w. Stanisława tak się dzieje. Długosz jako pierwszy opisał dziecięce lata krakowskiego ordynariusza. Już w XIII w. dominikanin Wincenty, opracowując żywot św. Stanisława, nie był w stanie zdobyć żadnej informacji na temat jego wczesnych losów. Wiedział jednak, że takie wiadomości powinny się w żywocie znaleźćc ${ }^{64}$. Za to Długosz-hagiograf, mając świadomość wymagań konwencji (i, zapewne, oczekiwań odbiorców), postanowił uzupełnić „białe plamy” w historii świętego wedle reguł prawdopodobieństwa - tak jak robił to w innych dziełach ${ }^{65}$.

59 Dla porównania, w Złotej legendzie każdy żywot opatrzony jest zazwyczaj jedną bezpośrednią informacją o czasie zdarzeń: np. „św. Aleksy umarł 17 lipca roku Pańskiego 398” (s. 272) czy „zmarł on [św. Paweł pustelnik - H.R.] około roku 287” (s. 98). W Żywocie mniejszym nie pojawia się ani jedna data. W Rocznikach Długosz starał się podać datację nawet zdarzeń z czasów legendarnych; zob. M. Rzepiela, Jeszcze o miejscu dziejów legendarnych w polskiej historiografii średniowiecznej: Gall Anonim, Kadlubek, Dlugosz, w: Jan Dlugosz - w kręgu badań historyków i literaturoznawców, red. T. Giergiel, Sandomierz 2017, s. 57 n.

${ }^{60}$ Bezwzględne określenia czasowe pojawiają się w Żywocie większym 10 razy. Dotyczą lat: 1025, 1046, 1058, 1059,1072 (wzmiankowany dwukrotnie), 1079 (wzmiankowany dwukrotnie, w tym w formie daty dziennej, VMa 14, s. 383: „III ${ }^{\circ}$ ydus Aprilis, luna VI, feria quinta post octavas Pasche, qua cantatur »Surrexit pastor bonus«, sub Gregorio papa VII"”), 1088, 1253. Daty pojawiają się głównie w ekskursach historycznych.

${ }^{61}$ P. Nehring, Topika, s. 49 n.

${ }^{62} \dot{Z}$ ywot mniejszy, s. 142, przyp. 1 do rozdz. 8.

${ }^{63} \mathrm{~W}$ Żywocie większym zawarto jedynie: topiczny prolog, znaczenie imienia św. Stanisława (I 5), skrótową charakterystykę pochodzenia, dojrzałości, pilności i cnót młodego św. Stanisława (I 4, 6-7), opis postępowania św. Stanisława jako biskupa (I 8-13), pragnienie męczeńskiej śmierci (I 14).

${ }^{64} V M a$ I 4, s. 366 n.: „licet autem de nobili prosapia fuerit ortus, de ipsius tamen progenitoribus vel eorum nominibus ideo in hoc volumine nulla fit ad presens mencio, quia antiquitas temporis [...] hanc delevit oblivio". Analogiczny ustęp znajduje się w Żywocie mniejszym (VMi 1, s. 253 n.).

${ }^{65}$ Takimi samymi kryteriami dziejopis kierował się podczas pracy nad Katalogami biskupów polskich i Rocznikami. Ann., ks. 1, s. 56, 59, 61, 63 (list ded.) oraz ks. 12, s. 446 (1480 r.); J. Długosz, Catalogus episcoporum Posnaniensium, w: tenże, Opera, t. 1, s. 480: „veterum Pontificum [...] nomen, genus et originem non nisi per verisimilem coniecturam poteram aestimare"; E. Potkowski, Fikcja i historia u Dlugosza, Przegl. Hum., 12, 1987, s. 47-63; tenże, Wrocławscy Episcopi Romani u Jana Dlugosza, w: Lux Romana w Europie Środkowej ze szczególnym uwzględnieniem Ślaska, red. A. Barciak, Katowice 2001, s. 104 n. 
Rodziców św. Stanisława Długosz opisał jako bardzo pobożnych chrześcijan (co często spotykane w żywotach ${ }^{66}$ ), którzy nazywać mieli się Wielisław i Benigna alias Bogna ${ }^{67}$ (stanowi to przykład samodzielnej etymologizacji ${ }^{68}$ ), a ojciec św. Stanisława miał być rycerzem herbu Turzyna. Informację heraldyczną kanonik zaczerpnąć mógł z III, IV lub V redakcji Katalogu biskupów krakowskich, tylko w Żywocie nie powtórzył nazwy herbu zawartej w Katalogu, poprzestawszy na opisie jego wyglądu ${ }^{69}$. Już Wojciech Kętrzyński przypuszczał, że zawarte w III i IV redakcji imiona rodziców męczennika (Małgorzata i Prandota) są późniejszymi dodatkami, nieznanymi Długoszowi ${ }^{70}$. To może thumaczyć, dlaczego podał on w Żywocie imiona Wielisław i Bogna, korzystając z własnego zmysłu słowotwórczego (dziejopis wykorzystywał bowiem w swoich pracach poświadczone gdzie indziej imiona i „wymyślał” je - czy raczej wyinterpretowywał - dopiero wtedy, gdy nie dysponował żadnymi świadectwami źródłowymi; zob. niżej).

Dziejopis wywnioskował, że skoro św. Stanisław okazał się ponadprzeciętną osobą, wybijającą się na tle swoich współczesnych, jego rodzice również musieli być wyjątkowi - jak u innych świętych ${ }^{71}$. I tak ojciec świętego słynął sztuką wojenną i moralnością, a jego matka wyróżniała się pod względem pobożności ${ }^{72}$. Do tego przyjście św. Stanisława na świat musiało być podobne do narodzin podobnie niezwykłych osób - postaci biblijnych i świętych ${ }^{73}$. Bogna i Wielisław byli więc bezpłodni tak jak rodzice Izaaka (Rdz 20,17-21,5), Jakuba ( $\operatorname{Rdz} 25,19-27)$, Józefa ( $R d z$ 29,31; Rdz 37,3), Samsona (Sdz 13,1-14; Sdz 24-25) i Jana Chrzciciela (Łk 1,36, 39-45), gdyż - wytłumaczył kanonik - ,już tak od natury jest ustanowione, iż wszystko, co tylko ma być wielkim i długotrwałem, rodzi się później i powolniej"74. Fakt poczęcia dziecka przez niepłodnych rodziców stanowi jednocześnie topos wyboru świętego przez Boga (Łk 1,13-18, 41-45) ${ }^{75}$. Ponadto św. Stanisław urodził się tego dnia, co św. Anna i św. Joachim, rodzice Marii (26 lipca), a poród nastąpił w topicznym locus amoenus ('rozkoszne miejsce'), kiedy Bogna samodzielnie wypasała trzodę, i przebiegł całkiem bezboleśnie ${ }^{76}$. Po narodzinach syna Wielisław i Bogna postanowili żyć w czystości ${ }^{77}$. Święty Stanisław był według Długosza jedynakiem, co miało służyć pełniejszemu podobieństwu do wyżej wymienionych Izaaka, Jakuba, Józefa, Samsona i Jana Chrzciciela. Elementem konwencji, często spotykanym chociażby w Biblii (np. Mt 16,18), jest w Żywocie także passus dotyczący etymologii imienia św. Stanisława, który Długosz zaczerpnął z wcześniejszych prac dominikanina Wincentego ( VMi 2; VMa I 5) ${ }^{78}$.

${ }^{66}$ P. Nehring, Topika, s. 67 n.

67 J. Długosz, Catalogus episcoporum Cracoviensium, w: tenże, Opera, t. 1, s. 388.

68 J. Banaszkiewicz, Teoria etymologii ludowej a średniowieczne etymologizowanie, Kwart. Hist., 81, 1974, nr 3, s. $593-599$.

69 VSt, s. 9: „crucem candidam unam super dimidiam, in campo rubeo, deferens pro insigni”; Katalogi biskupów krakowskich, s. 45 (III red.), 55 (IV red.), 85 (V red.).

70 Katalogi biskupów krakowskich, wyd. W. Kętrzyński, w: MPH, t. 3, Lwów 1878, s. 342, przyp. 3.

${ }^{71}$ Por. Złota legenda: św. Mikołaj (s. 64), św. Anastazja (s. 72), św. Sebastian (s. 116), św. Grzegorz papież (s. 164), św. Teodora (s. 263), św. Aleksy (s. 268), św. Maria Magdalena (s. 274), Siedmiu Braci Śpiących (s. 297), św. Marta (s. 302), św. German (s. 307), św. Bernard (s. 352), św. Augustyn (s. 370), św. Idzi (s. 383), św. Hieronim (s. 425), św. Pelagia (s. 446), św. Leonard (s. 461), św. Chryzant (s. 466), św. Cecylia (s. 502), św. Klemens papież (s. 507), św. Wojciech (s. 535).

72 VSt, s. 9 (o ojcu św. Stanisława): „non tam nobilitate pollens generis, quam virtutum splendore: vir ex militari ordine et equestri, et qui inter omnes domus et familiae suae contribules, primarius et praecipuus habebatur, sed et inter alios Polonorum proceres, morum et virtutum iubare, militarisque rei gloria eminebat”; tamże (o jego matce): „femina [...] genere ingenua, sed pudicitiae magis decore nobilior, de raris religiosa femina, clara et celebris inter feminas suae regionis suique temporis habebatur".

73 Por. Zlota legenda: św. Remigiusz (s. 100).

74 Życie św. Stanisława, s. 19; VSt, s. 11: „cum a natura ita comparatum foret, magna et diu duratura solere tardius nasci”.

75 Zob. D. Wójcik, Wątki biblijne w legendzie „,Tempore illo” świętego Wojciecha, „Nasza Przeszłość”, 94, 2000, s. 23.

76 VSt, s. 10: „dum post lustratos sub meridionali tempore greges in aedem ex propinquo nemore reverteretur, ad puteum, haud longe ab habitaculo suo inter quercus et dumeta consistentem, filium pulcherrimum, nullo obstetricis interveniente suffragio, [...] in aevo iam maturato et senescenti, effudit, atque in fonte, ad quem parturierat, lotum, domum laeta et incolumis retulit, nullum dolorem, nullam debilitatem in partu iuxta ac post partum experta”; E.R. Curtius, Literatura europejska i łacińskie średniowiecze, thum. i oprac. A. Borowski, Kraków 2009, s. 202; P. Bering, Struktury narracyjne, s. $111 \mathrm{n}$.

77 Por. Złota legenda: św. Mikołaj (s. 64), św. Aleksy (s. 268).

${ }^{78}$ E.R. Curtius, Literatura europejska, s. 520; D. Wójcik, Wątki biblijne, s. 23; VMi, s. 254 n.; VMa, s. 367 n. 
Według konwencji obowiązującej w piśmiennictwie hagiograficznym w konstrukcji postaci świętego nie widać kształtowania się jego osobowości, brak też psychologicznej analizy rozwoju wewnętrznego charakter św. Stanisława jest w pełni uformowany już od wczesnej młodości, a wszystkie cechy jego charakteru ukazywane są przez czyny. Poza tym męczennik od najmłodszych lat przejawiał dorosłość godna mędrca (topos puer senex ${ }^{79}$ ), był pobożny i wstrzemięźliwy w jedzeniu, piciu, zabawie, a nawet śnie. Jego asceza nie obejmowała jednak zaniedbania higieny - wręcz przeciwnie, Długosz podkreślił dbałość św. Stanisława o czystość ciała ${ }^{80}$. Według kanonika św. Stanisław od dzieciństwa aż do męczeńskiej śmierci miał unikać bezczynności i zajmować się czy to nauką, czy to modlitwą, lekturą i pobożnym rozmyślaniem ${ }^{81}$. Charakterystycznym elementem twórczości żywotopisarskiej jest także wczesne sieroctwo świętego i rozdanie całego odziedziczonego majątku ubogim ${ }^{82}$. Poza Zlota legenda motyw ten obecny jest już w późnoantycznych żywotach, na które kanonik powołał się w prologu ${ }^{83}$. W omawianym dziele rodzice św. Stanisława umrzeć mieli w czasie jego pobytu na zagranicznych studiach, o czym święty miał dowiedzieć się już po powrocie do kraju.

Ponadto typowym motywem hagiograficznym jest pragnienie ucieczki od świata doczesnego i poświęcenia życia Bogu w klasztorze. Topos ten pojawia się w Biblii (Rdz 12,1-5; Wj 14; Mt 8,19-20; Mt 9,9; Mk 10,21; J 1,38-39) oraz w żywotach św. Hilariona i św. Marcina z Tours, a także w Złotej legendzie ${ }^{84}$. W żywocie pióra Długosza św. Stanisław chciał wstąpić do zakonu już podczas pobytu we Francji, a potem także w Polsce, ale - znów konwencjonalnie - Bóg zmienił jego zamiar, ponieważ przeznaczył go do innych zadań ${ }^{85}$. Mimo że św. Stanisław nie został mnichem, jego zachowanie odpowiadało toposowi monastycznej pokory i ubóstwa, mającemu źródło w Biblii (np. Syr 18,30-33; Mt 5,3-11; Łk 14,11). Kolejną odsłoną motywu unikania spraw ziemskich jest odmowa przyjęcia wysokiej godności kościelnej. Ten topos wielokrotnie występuje w Złotej legendzie ${ }^{86}$. Pojawia się on także w Żywocie św. Stanisława, wedle którego przyszły męczennik już po śmierci Lamberta Suły i elekcji na jego następcę starał się przekonać tych, którzy go wybrali, do zmiany zdania ${ }^{87}$. Ponieważ jednak wszyscy decydenci byli jednomyślni, św. Stanisław postanowił nie sprzeciwiać się ich woli, uzewnętrzniającej wolę samego Boga ${ }^{88}$. A miały to być nie tylko głosy licznych duchownych krakowskich, ale i wielu rycerzy, obywateli i chłopów (militarium, civium et agrestium) z sąsiednich miasteczek i wsi ${ }^{89}$. Taki sam wątek zawierają zarówno liczne z opowieści ze Złotej legendy ${ }^{90}$, jak i żywot św. Marcina

79 E.R. Curtius, Literatura europejska, s. 108-109; D. Wójcik, Wątki biblijne, s. 24.

80 VSt, s. 12: ,in villagium Borowno pervenisset, balnea pro militibus villae adaptata ingressus, corpus curare et abluere pergeret”; zob. Red[akcja], Jan Dlugosz o wielkopolskiej przygodzie św. Stanisława ze Szczepanowa, „Kronika Miasta Poznania", 62, 1994, nr 3-4, s. 140-142.

81 Por. Złota legenda: św. Mikołaj (s. 64), św. Dominik (s. 323), św. Wojciech (s. 537).

82 P. Nehring, Topika, s. 35; por. Złota legenda: św. Mikołaj (s. 64), św. Antoni (s. 110), św. Grzegorz papież (s. 164), Siedmiu Braci Śpiących (s. 297), św. Idzi (s. 383).

${ }^{83}$ Hieronim ze Strydonu, Żywot św. Pawła 4-5 (s. 93 n.); tenże, Żywot św. Hilariona 3 (s. 119); tenże, Żywot Malchusa 3 (s. 180); tenże, List 108.5 (s. 162).

${ }^{84}$ D. Wójcik, Wątki biblijne, s. 24; Hieronim ze Strydonu, Żywot św. Hilariona 8.6 (s. 128); Sulpicjusz Sewer, Żywot św. Marcina 9 (s. 69-71); por. Złota legenda: św. Remigiusz (s. 100), św. Marcin (s. 491), narodziny Najświętszej Marii Panny (s. 390-392, gdzie chwalona jest postawa pewnego kleryka).

85 VSt, s. 14: „sed hunc ipsius conceptum, ne ab eo perficeretur, maiori illum certamini, quam quod in coenobio geri solitum est, Dominus reservans, avertit"; por. Złota legenda: św. Dominik (s. 324 n., gdzie Bóg nie pozwolił św. Dominikowi na sprzedanie się do niewoli dla oswobodzenia pewnego jeńca saraceńskiego).

${ }^{86}$ Por. Złota legenda: św. Mikołaj (s. 65), św. Sylwester papież (s. 89), św. Grzegorz papież (s. 166), św. Dominik (s. 333), św. Bernard (s. 358), św. Augustyn (s. 373 n.), św. Idzi (s. 385), św. Leonard (s. 461), św. Marcin (s. 493), św. Klemens papież (s. 513), św. Wojciech (s. 536).

87 VSt, s. 16: „obibat ipse singulorum domos et ianuas, et se illo culmine longa persuasione ostendebat indignum”.

${ }^{88}$ VSt, s. 17: „electioni suae profundo satis et verecundo pudore, vix tandem praebuit assensum; ne ordinationi divinae videretur refragari, quae per tot ora et suffragia humana sibi innotescebat".

89 VSt, s. 16.

${ }^{90}$ Por. Złota legenda: św. Sylwester (s. 89), św. Remigiusz (s. 100), św. Błażej (s. 151), św. Grzegorz papież (s. 166), św. German (s. 307), św. Marcin (s. 493), św. Wojciech (s. 536). 
wzmiankowany przez Długosza w prologu ${ }^{91}$. O ile w okresie wczesnochrześcijańskim faktycznie ordynariusz wybierany był przez kler danego Kościoła i biskupów okolicznych ośrodków (a w praktyce głównie dzięki poparciu ludzi świeckich), w czasach Długosza decydował wynik elekcji kapitulnej (często zależny od opinii monarchy). Za to wcześniej, np. za czasów Bolesława Śmiałego, to monarcha mianował biskupa (choć Długosz, patrząc ahistorycznie, skłonny był widzieć wybory kanoniczne już w połowie XI w. - na początku XII w. ${ }^{92}$ ).W takich okolicznościach wzmiankę Długosza o wyborze św. Stanisława przez aklamację należy uznać za kolejny element konwencjonalny.

Święty Stanisław jako biskup krakowski wyróżniał się cechami idealnego pasterza spotykanymi w Biblii (1 Tm 3,1-7; Tt 1,7-993) i żywotopisarstwie. Był więc pobożny, miłosierny i pracowity ${ }^{94}$. Żył w sposób ascetyczny ${ }^{95}$. Z usposobienia był stateczny - ani wesoły, ani smutny czy zagniewany, zawsze cierpliwy ${ }^{96}$. Uwypuklona została też jego sprawiedliwość oraz troska o moralność duchowieństwa i wiernych. Długosz podkreślił, że w razie konieczności św. Stanisław surowo napominał i gorliwie karcił tych, którzy na to zasłużyli97 (miało to być wprowadzenie do wątku konfliktu z królem, które jednocześnie stanowiło nawiązanie do toposu gorliwości pasterskiej znanego z Biblii: J 2,13-1798).

Późniejsza narracja dotycząca cudu piotrawińskiego, konfliktu św. Stanisława z królem Bolesławem i męczeńskiej śmierci została ukształtowana w ścisłej zależności od pierwszych żywotów św. Stanisława, dlatego rozpatruję ją w dalszej części artykułu. Na razie chciałabym zwrócić uwagę na kilka stricte topicznych elementów umieszczonych przez Długosza w końcowej części tractatus I.

Często spotykanym w hagiograficznym piśmiennictwie motywem związanym ze śmiercią świętego jest prośba jego towarzyszy, by nie umierał czy też nie dał się zabić. W Żywocie św. Stanisława otoczenie biskupa żywiło przekonanie, że jeśli nie przestanie on karcić króla (zrobił to bowiem więcej niż jeden raz), zginie, dlatego stronnicy ordynariusza prosili go o zaprzestanie upominania władcy oraz większą troskę o swoje życie i los krakowskiego Kościoła. Tymczasem św. Stanisław - także zgodnie z konwencją gatunku ${ }^{99}$ - czuł się gotowy do poniesienia męczeństwa, a nawet go pragną ${ }^{100}$. Źródłem tego toposu hagiograficznego jest Biblia (Mt 24,9; Dz 5,41; 2 Kor 5,1-6; Flp 1,20-24) ${ }^{101}$.

Gdy Bolesław Śmiały chciał uśmiercić biskupa, wysłał do kościoła oddział swojego wojska w celu zabicia hierarchy. Jednak z Bożej woli rycerzy dopadł nagły strach, upadli w tył, po czym skruszeni wybiegli z kościoła, nie wykonawszy rozkazu. Kiedy sytuacja powtórzyła się trzykrotnie, rozszalały ze złości król własnoręcznie zabił biskupa. Jak wykazała Danuta Borawska, scena ta pozostaje w ścisłej zależności z narracjami XII-wiecznych żywotów św. Tomasza Becketa, arcybiskupa Canterbury $(X I I ~ w .)^{102}$. Poza tym topos ,złudzeń zabójców” spotkać można w Biblii $(\mathrm{J} 18,6)$, a także w żywotach

${ }^{91}$ Sulpicjusz Sewer, Żywot św. Marcina 9 (s. 70).

${ }_{92}$ Ann., ks. 3, s. 71 (1055 r.); s. 77 (1058 r.); s. 80 (1059 r.); s. 85 (1062 r.); Ann., ks. 4, s. 158 (1087 r.); s. 159 (1087 r.).

93 D. Wójcik, Wątki biblijne, s. 24 (tamże jako „topos niezwykłych zalet kandydata na biskupstwo”).

${ }^{94}$ Por. Złota legenda: św. Dominik (s. 333), św. Marcin (s. 496). Informacja o posiadaniu spisu miejscowych wdów, sierot oraz biedaków i wspomaganiu ich była również elementem konwencjonalnym; por. tamże: św. Sylwester papież (s. 89), św. Grzegorz papież (s. 166), św. Klemens papież (s. 513). Długosz zmodyfikował w Żywocie Wincentyńskie wyrażenie, że św. Stanisław „viduas, pupillos et orphanos, quos per episcopatum suum quasi in libro memorie conscriptos habebat, eos eleemosinis suis [...] sustentabat" (VMa I 12, s. 372) - według kanonika biskup miał księgę ze spisem potrzebujących. Ciągłe zajęcie miało odciągać od grzechu; por. Złota legenda: św. Piotr męczennik (s. 215), św. Bernard (s. 359).

${ }^{95}$ Por. Zlota legenda: św. German (s. 307 n.), św. Bernard (s. 355), św. Cecylia (s. 502).

${ }^{96}$ Por. tamże: św. Marcin (s. 495).

97 Por. tamże: św. Mikołaj (s. 65), św. Grzegorz papież (s. 170).

${ }_{98}$ D. Wójcik, Wątki biblijne, s. 24.

99 Por. Złota legenda: św. Antoni (s. 110), św. Julian (s. 138), św. Ignacy (s. 144-146), św. Piotr męczennik (s. 215), św. Piotr apostoł (s. 249), św. św. Szymon i Juda apostołowie (s. 474), św. Wojciech (s. 540, 542, 545 n.).

${ }^{100}$ VSt, s. 57: „velut vas electionis a Domino dudum praevisus, huiusmodi precibus inflammatior, et ad amorem martyrii [...] alacrior fervidiorque reddebatur. [...] id nocte atque interdiu meditabatur; haec sua assidua cum viris ecclesiasticis consultatio, haec ad Deum profunda deprecatio, ut mori sibi pro suo nomine et honore tribueret"; zob. P. Nehring, Topika, S. 88 .

101 D. Wójcik, Wątki biblijne, s. 25.

102 D. Borawska, Z dziejów jednej legendy. W sprawie genezy kultu św. Stanisława biskupa, Warszawa 1951, s. $20-27$. 
świętych, kiedy atak złoczyńców na świętego zostaje niespodziewanie udaremniony, tak jak w Złotej legendzie czy w żywocie św. Marcina przywołanym przez Długosza w prologu ${ }^{103}$. Po opisie śmierci protagonisty do żywotów często wplatany jest passus o powszechnej rozpaczy z powodu odejścia świętego ${ }^{104}$. Taki motyw zastosował i Długosz w omawianym dziele ${ }^{105}$.

Obecna w Długoszowym Żywocie scena wniebowzięcia św. Stanisława, spotkania z Chrystusem i zbawionymi duszami w niebie, pochwały Jezusa wobec męczennika i ofiarowanie mu kwietnej korony, a także dialog tych dwu postaci wedle Kazimierza Krotoskiego podyktowane zostały jedynie „pobożną fantazją wiary” kanonika ${ }^{106}$. Tymczasem świadectwa innych żywotów dowodzą, że jest to uznany w literaturze hagiograficznej motyw, spotykany także we wzmiankowanym przez Długosza żywocie św. Pawła eremity czy w Złotej legendzie ${ }^{107}$. Ponadto przypisane Chrystusowi słowa skierowane do św. Stanisława: „vidi certamen, vidi agonem tuum” można uznać za wykorzystanie biblijnego toposu athletae Christi, czyli osoby walczącej w obronie wiary $(2 \mathrm{Tm} 4,7)^{108}$.

Konwencjonalny charakter ma również opis cudów związanych z ciałem św. Stanisława: zrośnięcie się kończyn w całość, słodki odor sanctitatis, ochrona relikwii zapewniona przez zwierzęta oraz blask niebieskich świateł w pobliżu miejsca śmierci biskupa ${ }^{109}$. Motywy takie zastosowano chociażby w Złotej legendzie czy w źródłach przywołanych przez D. Borawską: Pasji św. Wojciecha, Żywocie Pięciu Braci Męczenników Brunona z Kwerfurtu, Żywocie św. Wacława i Żywocie św. Stefana ${ }^{110}$.

Także i koniec życia Bolesława Śmiałego opisany został przez Długosza w sposób zapewne topiczny. Zbrodniczy władca, już po ucieczce na Węgry i zdemaskowaniu przez tamtejszego króla Władysława i jego dostojników, w drugim roku wygnania oszalał i uciekł do lasu, gdzie zabłąkał się i zmarł, a jego ciało poszarpały i pożarły jego własne psy ${ }^{111}$. Dziejopis dodał, że taka właśnie kara była najwłaściwsza dla Bolesława, który wcześniej kazał pociąć i rzucić na pożarcie dzikim zwierzętom ciało krakowskiego biskupa ${ }^{112}$. Jak przedstawił Paweł Żmudzki, paralelę opisu śmierci bohatera literackiego zjedzonego czy pogryzionego przez psy znaleźć można w Kronice ziemi pruskiej Piotra z Dusburga

${ }_{103}$ D. Wójcik, Wątki biblijne, s. 25 (stąd także nazwa toposu); P. Nehring, Topika, s. 88; por. Złota legenda: św. św. Wit i Modest (s. 233), św. Jakub Starszy apostoł (s. 286), św. Krzysztof (s. 294), narodziny Najświętszej Marii Panny (s. 390, gdzie Maria dwukrotnie uniemożliwiła uśmiercenie jej czciciela-złodzieja), św. Marcin (s. 492); Sulpicjusz Sewer, Żywot św. Marcina 5 (s. 64 n.).

104 P. Nehring, Topika, s. 76, 78; por. Zlota legenda: św. Wojciech (s. 545).

105 VSt, s. 70: „occisione beati viri Stanislai Episcopi [...] in graves lacrymas et lamenta primum [...] universa Cracoviensis provocata est mater Ecclesia. [...] flebat propter viduationem, quod tam speciosum et carissimum prae filiis hominum sponsum sibi dolebat ablatum: gemebatque et in gemitu suo ac suspiriis per singulas noctes lectum lacrymis rigabat, erantque iuges lacrymae in maxillis eius".

106 VSt, s. 69 n.; por. K. Krotoski, Ś. Stanisław biskup, s. 95, wedle którego taki dialog nawet „razi nieco nasze uczucia religijne"; por. D. Turkowska, Etudes, s. 46, która wędrówkę duszy św. Stanisława do nieba uznała za wpływ platonizmu.

107 Hieronim ze Strydonu, Żywot św. Pawła 14 (s. 108, zob. też tamże, przyp. 104, gdzie podano kolejne przykłady zastosowania tego motywu); por. Złota legenda: św. Paweł pustelnik (s. 97), św. Antoni (s. 111), św. Benedykt (s. 182), św. Piotr apostoł (s. 249 n.), św. Maria Magdalena (s. 280, 282 - w drugim przypadku święta asystowała przy śmierci pewnego kleryka), św. Marta (s. 303 n. - w pierwszym przypadku święta widziała, jak aniołowie prowadzili jej siostrę do nieba), wniebowzięcie Najświętszej Marii Panny (s. 341 n., 344), św. Idzi (s. 386), św. Dionizy (s. 458), św. Marcin (s. 498 n.).

108 VSt, s. 70; D. Wójcik, Wątki biblijne, s. 25.

109 P. Nehring, Topika, s. 79.

110 Por. Złota legenda: św. Piotr męczennik (s. 218), św. św. Wit i Modest (s. 234), św. Paweł apostoł (s. 260), wniebowzięcie Najświętszej Marii Panny (s. 342), św. Dionizy (s. 458), św. Wojciech (s. 547), św. Florian (s. 551); D. Borawska, Z dziejów jednej legendy, s. $26 \mathrm{n}$.

111 VSt, s. 87: „secundo [...] anno sui exilii subito languore correptus, et in amentiam versus, in Alpes, silvas, nemora atque in loca avia, [...] delirando petens, et in illis discurrens, a propriis canibus, illum tantummodo comitantibus, dum fessus et anhelus animam morte repentina exhalasset, comestus et devoratus, teterrimo illo supplicio affectus, impiam vitam digna morte finivit”; por. Ann., ks. 3, s. 144 (1081 r.): ,a nonnullis vero asseritur, dum in Hungaria aput beatum regem Wladislaum consisteret, in amenciam versus, tamdiu cruciatus et molestias demencie, donec animam [...] exalaret, pertulisse a canibusque propriis in silvis Pannonicis voratum esse"; J. Banaszkiewicz, Czarna i biała legenda Bolesława Śmiałego, Kwart. Hist., 88, 1981, nr 2, s. 366-367.

112 VSt, s. 87 n. 
(XIII-XIV w.) i w Roczniku Traski (XIV w.) ${ }^{113}$ - może to być element topiki narracyjnej, choć nie stricte hagiograficznej.

\section{Argumentatio}

Argumentatio (probatio) stanowi najważniejszą część mowy, w której orator przeprowadza wnioskowanie, starając się przekonać odbiorców do swojej sprawy. Prologus i narratio są jedynie podstawą, na której oparte jest dowodzenie w partii argumentacyjnej ${ }^{114}$. W hagiografii argumentatio nie miała własnej, wydzielonej części dzieła. Składały się na nią pewne całostki argumentacyjne porozsiewane w całym żywocie, które na różnych etapach lektury miały przekonywać odbiorcę o świętości bohatera dzieła.

Retor może dowodzić swoich racji bez wykorzystania zabiegów retorycznych (genus inartificiale probationum) przez przytaczanie przykładów i świadectw. Może on też oprzeć argumentację na swoich umiejętnościach oratorskich (genus artificiale probationum), przeprowadzając dowodzenie przez signa, argumenta lub exempla ${ }^{115}$. Za signa uznaje się zmysłowo postrzegalne znaki, mające stanowić potwierdzenie stanowiska zajmowanego przez twórcę. Mimo podobieństwa do środków niezależnych od kunsztu mówcy signa różnią się od nich tym, że należy je uzasadnić i wykazać ich związek ze sprawą, zatem wykorzystanie ich potencjału zależy wyłącznie od umiejętności retora. Argumentum to dowód budowany jako wniosek z przesłanek danych w sprawie, który poza nią nie ma znaczenia ani zastosowania. Aby móc wykorzystać argumentum w danej sprawie, należy powołać się w nim na coś, co dzięki swojej wiarygodności nie będzie budziło sprzeciwu odbiorców. Argumentum może zostać uznane za pewne (czyli niepodważalne), jeśli spełnia któreś z następujących kryteriów: (1) jest zmysłowo poznawalne, (2) powszechnie uznane, (3) ustanowione mocą prawa, (4) ustalone mocą zwyczaju obowiązującego w środowisku, w którym toczy się sprawa/akcja utworu, (5) zgadzają się co do tego obie strony, (6) zostało to wcześniej dowiedzione lub (7) w danej sprawie nie sprzeciwia się temu oponent. Exemplum zaś jest metodą dowodzenia przez porównanie rozważanej sprawy z wydarzeniem zaszłym w przeszłości lub z prawidłowością, której zaistnienia można się spodziewać. Co istotne, wydarzenie traktowane jako exemplum nie należy bezpośrednio do omawianej sprawy. Dopiero przez indukcję mówca wykazuje związek exemplum ze sprawą (zwykle ich podobieństwo) i zaprzęga exemplum do swojej argumentacji.

W dziełach hagiograficznych argumenty (czasem nazywane loci) można było czerpać z osoby, tzn. bohatera utworu (loci a persona) ${ }^{116}$ : jego pochodzenia (genus), imienia (nomen), niezwykłych okoliczności narodzin (quid in nascendo evenit mirum), sposobu życia (victus), wykształcenia i wychowania (educatio et disciplina), cech charakteru i wyglądu (natura animi corporisque), zajęć (studia), czynów (gesta), długości życia (tempus; w przypadku świętych-wyznawców), okoliczności śmierci i wydarzeń, które nastąpiły po niej (qualitas mortis), a także z porównań (comparatio). Poza tym źródłem argumentów była sprawa (loci a re $)^{117}$ : jej przyczyna, miejsce, czas i sposób dokonania, okoliczności umożliwiające jej zajście, ewentualnie także zakończenie, podobieństwo do innych spraw, porównania i okoliczności towarzyszące.

113 P. Żmudzki, Psy Jaćwingów. Dlaczego Marcin Kromer zinterpretowat rocznikarska zapiskę o zwycięstwie Leszka Czarnego inaczej niż Jan Dlugosz, w: Historia narrat. Studia mediewistyczne ofiarowane profesorowi Jackowi Banaszkiewiczowi, red. A. Pleszczyński, J. Sobiesiak, M. Tomaszek, P. Tyszka, Lublin 2012, s. 75-94, zwł. s. 75 n., 79 n.

114 P. Nehring, Topika, s. 63-113; H. Lausberg, Retoryka literacka, s. 206-262.

115 Więcej na temat exemplum zob. T. Szostek, Exemplum w polskim średniowieczu, Warszawa 1997.

116 Zestaw loci a persona zaczerpnęłam z: P. Nehring, Topika, s. 65; H. Lausberg, Retoryka literacka, s. 223-226. Pochodzą one z dzieła gramatyka Pryscjana (V-VI w.) De rhetorica (in. Praeexercitamina), wyd.: Priscianus, Libri minores, wyd. M. Passalacqua, Rome 1987, s. 430-440, pol. przekład: Pryscjan z Cezarei, Ćwiczenia wstepne, tłum. H. Matyja, w: Źródła wiedzy teoretycznoliterackiej w dawnej Polsce. Średniowiecze, Renesans, Barok, wstęp, wybór i oprac. M. Cytowska, T. Michałowska, Warszawa 1999, s. 107-113; zob. B. Grondkowska, Retoryczność średniowiecznych żywotów świętych na podstawie „De vita et miraculis fratris Johannis Ruusbroec” Henryka Pomeriusza, w: Kultura pisma w średniowieczu. Znane problemy - nowe metody, red. A. Adamska, P. Kras, Lublin 2013, s. 256.

117 Zestaw loci a re zaczerpnęłam z: P. Nehring, Topika, s. 65; H. Lausberg, Retoryka literacka, s. 226-243. 
W Żywocie św. Stanisława Długosz wykorzystał wszystkie możliwe sposoby dowiedzenia świętości biskupa-męczennika. Zastosował genus inartificiale probationum, przytaczając in extenso aż cztery pisma dotyczące kanonizacji św. Stanisława: list Innocentego IV do jego delegata, franciszkanina Jakuba z Velletri, list kardynała Giovanniego Gaetano Orsiniego, kardynała diakona kościoła św. Mikołaja w Więzieniu, do ordynariusza krakowskiego Prandoty, oraz listy kanonizacyjne przesłane przez papieża Innocentego IV biskupowi krakowskiemu Prandocie i innym polskim hierarchom ${ }^{118}$. Tak dużą liczbę cytowanych pism łączyć należy z jednej strony z kancelaryjną i dziejopisarską praktyką Długosza, docenianiem wartości dokumentów i zainteresowaniem nimi, z drugiej zaś z chęcią przedstawienia dodatkowych (zewnętrznych) świadectw za świętością krakowskiego męczennika ${ }^{119}$.

Co do zastosowania genus artificiale probationum, kanonik posłużył się dowodzeniem przez signa, przytaczając miracula spisane w okresie przed- i pokanonizacyjnym. Dla spełnienia swojej funkcji retorycznej musiały one być prawdopodobne oraz szczegółowe, dlatego w każdej relacji Długosz podał następujące informacje (w mniej lub bardziej rozwiniętej formie): kto (quis), co (quid), dlaczego (cur), kiedy (quando), jak (quomodo), z czyją pomocą (quibus adminiculis) ${ }^{120}$. Celem było takie opisanie zdarzeń, jakby naprawdę mogły one mieć miejsce. Wiarygodność relacji podnoszono w hagiografii przez podkreślanie źródła danej informacji, np. dokumentu czy naocznych świadków, którzy dodatkowo określani byli jako „pobożni” lub ,wiarygodni” ${ }^{21}$. Gdy w źródle Długosza nie było informacji o imieniu świadka danego cudu, dziejopis nadawał mu je samodzielnie - zależnie od płci był to Świętosław ${ }^{122}$ lub Świętosława ${ }^{123}$ (w tym przypadku samo imię miało zwiększać wiarygodność świadectwa). Oprócz tego autorzy żywotów chętnie powoływali się na własne doświadczenie (zrobił to i Długosz, a przytoczona przez niego opowieść jest bardzo rozbudowana ${ }^{124}$ ).

O funkcji argumentacyjnej cudów stanowiło ich tematyczne pogrupowanie, zastosowane i w $\dot{Z} y$ wocie większym św. Stanisława (1. wskrzeszenia zmarłych, 2. wyleczenia wrzodów, 3. uzdrowienia z szaleństwa, 4. uratowania utopionych lub zagrożonych utonięciem, 5. cuda na zwierzętach) ${ }^{125}$, i w żywocie Długoszowym (1. wskrzeszenia, 2. choroby oczu, 3. wrzody, paraliże, epilepsje, 4. umierający, umysłowo chorzy i inni, 5. różni chorzy, tonący, pożary). Cuda przedstawiane w żywotach były wyraźnie wzorowane na biblijnych (wskrzeszenia, paraliże, choroby skóry) ${ }^{126}$. Oprócz tego z autorytetu Biblii korzystano dla podniesienia wiarygodności opisywanych zdarzeń, np. przyrównując czyny świętych do losów postaci historii świętej ${ }^{127}$. Dla celów dydaktycznych w żywotach zawsze jasno thumaczono odbiorcy intencje świętego i wyjaśniano najważniejsze podejmowane przezeń decyzje. W omawianym dziele np. narrator tłumaczył wielkość cudu piotrawińskiego ${ }^{128}$.

118 VSt, s. 133 n., 139-141, 142-148.

119 Znamienne są słowa dziejopisa (VSt, s. 2): „etiam prodigia [...]; item et Canonisationis suae Bullas Apostolicas praesenti operi inserui: ut munus cumulatius et tibi et legentibus elargirer, simul quoque rem dignam iudicans, quae proprii operis narrationem habere mereretur". Podobny pogląd wyraził w Rocznikach: ks. 1, s. 63 (list ded.).

${ }^{120}$ P. Nehring, Topika, s. 50.

121 Tamże, s. 55.

122 VSt, s. 128-130: „Swyanthoslaus, oppidi episcopalis Slawkow civis, arte coriarius, vir simplex et rectus, ac in Deum rarae devotionis”; por. VMa III 54, s. 432: „quidam de Slavcow coriarius, homo simplex et devotus”.

123 VSt, s. 95 n.: ,dum ad tumulum suum femina religiosa et nobilis Swanthoslawa frequentes sub profundis noctibus ageret excubias"; por. VMa III 1, s. 393: ,,apparuit gloriosus pontifex cuidam nobili matrone, que locum eius sepulture solita erat frequentare".

124 VSt, s. 179-181: „a quo ego Iohannes Dlugosch omnia haec ex narratione sua personaliter accepi”.

125 M. Plezia, Żywot większy św. Stanisława, w: Średniowieczne żywoty i cuda, s. 244.

126 Por. wskazane przez D. Wójcik, Watki biblijne, s. 24, przykłady toposu choroby i cudownego uzdrowienia obecne w Biblii: $1 \mathrm{Krl}$ 17,17-23 oraz Łk 7,11-17 i Łk 8,49-56, a także Mt 15,21-28; wszystkie te przykłady dotyczą uzdrowień dzieci.

127 W Żywocie znajdują się nawiązania do następujących postaci i zdarzeń: Kain i Abel (VSt, s. 10), Melchizedek (tamże, s. 17), prorok Eliasz i Jan Chrzciciel (tamże, s. 29), wskrzeszenie Łazarza i córki przełożonego synagogi (tamże, s. 38), Samuel i Saul (tamże, s. 57), Chrystus w Ogrodzie Oliwnym (tamże, s. 64 n.), Jan Chrzciciel (tamże, s. 76), Hiob (tamże, s. 87).

128 VSt, s. 43: ,quid enim pro illo tempore apud Polonicam Ecclesiam mirabilius [...] Stanislao [...]? Qui hominem ante triennium resolutum [...], quod mortalium pectora non solum non credere, sed nec suspicari poterant, conditionis quodammodo suae oblitus, se in testem producturum astruxit: ea nimirum fretus fide, quasi in potestate sua et arbitrio vita et mors consisterent; et crederet se perficere per fidem, quod homines nullatenus assensuros sciebat per credulitatem". 
Długosz dowodził świętości krakowskiego biskupa także przez argumenta. W Żywocie św. Stanistawa wykorzystał liczne loci a persona:

Tabela 1. Loci a persona w Żywocie św. Stanisława Jana Długosza

\begin{tabular}{|l|l|l|}
\hline \multirow{4}{*}{ Arg. } & a genere $:$ & rodzice szlachetnego rodu, zamożni i pobożni \\
\cline { 2 - 3 } & a nomine: & etymologia imienia (Stanisław - stanie się sławny) \\
\hline a circumstantia nativitatis: & niepłodni rodzice, bezbolesny poród, urodziny w dniu narodzin rodziców Marii \\
\hline a victu: & pobożność, dobrowolne akty miłosierdzia od najmłodszych lat \\
\hline ab educatione et discplina: & pojętność, bystrość, dobra pamięć, pracowitość \\
\hline a natura animi corporisque: & $\begin{array}{l}\text { stateczność, wczesna dojrzałość, pokora, cnotliwość, asceza (w młodości i doro- } \\
\text { słym życiu) }\end{array}$ \\
\hline \multirow{2}{*}{ a studiis: } & $\begin{array}{l}\text { pragnienie kształcenia się, dążenie do doskonałości, uznanie starszych uczonych } \\
\text { mężów, zachęty do doktoryzacji }\end{array}$ \\
\hline a gestis: & $\begin{array}{l}\text { pragnienie poświęcenia życia Bogu, dbałość o dobro diecezji i państwa oraz wier- } \\
\text { nych, sprawiedliwość, nieugiętość, gotowość do poświęceń w imię wyznawanych } \\
\text { zasad, wskrzeszenie zmarłego }\end{array}$ \\
\hline \multirow{2}{*}{ a qualitate mortis: } & $\begin{array}{l}\text { cuda związane z ciałem (ognie zstępujące z nieba na porąbane członki, zrośnię- } \\
\text { cie się ciała, cztery orły pilnujące zwłok, odor sanctitatis, lecznicze właściwości } \\
\text { relikwii) }\end{array}$ \\
\hline a comparatione: & $\begin{array}{l}\text { ze względu na narodziny: Izaak, Jakub, Józef, Samson, Jan Chrzciciel; ze } \\
\text { względu na dzieje życia: Melchizedek, Samuel, prorok Eliasz, Jan Chrzciciel }\end{array}$ \\
\hline
\end{tabular}

Za to loci a re znaleźć można np. w opowieści o cudzie piotrawińskim, gdzie już we wprowadzeniu do kwestii Długosz przedstawił wszystkie możliwe argumenty przemawiające za legalnością transakcji zawartej między rycerzem Piotrem a biskupem Stanisławem, a zatem za przynależnością Piotrawina do diecezji krakowskiej ${ }^{129}$. Argumenty te przedstawiam w porządku występowania, parafrazując słowa dziejopisa.

Tabela 2. Loci a re w Żywocie św. Stanisława Jana Długosza

\begin{tabular}{|l|l|l|}
\hline \multirow{2}{*}{ Arg. } & a causa: & $\begin{array}{l}\text { ponieważ biskup, chcąc powiększyć dochody swojej diecezji, tak obracał powie- } \\
\text { rzonym sobie talentem, że uzyskał godziwy zysk }\end{array}$ \\
\cline { 2 - 3 } & a loco: & ponieważ Piotrawin jest położony na terenie diecezji krakowskiej \\
\cline { 2 - 3 } & a facultate: & ponieważ rycerz Piotr był jedynym dziedzicem Piotrawina \\
\cline { 2 - 3 } & a finitione: & ponieważ biskup w całości zapłacił Piotrowi za tę wieś \\
\hline \multirow{2}{*}{ a modo: } & $\begin{array}{l}\text { ponieważ transakcja została przeprowadzona z zachowaniem wszelkich wymaga- } \\
\text { nych wówczas formalności }\end{array}$ \\
\cline { 2 - 3 } ab auctoritate: & ponieważ król wiedział o sprawie i nie wyraził wówczas sprzeciwu \\
\hline a tempore: & ponieważ biskup zarządzał Piotrawinem już od trzech lat \\
\cline { 2 - 3 } & a circumstantia: & ponieważ przez te trzy lata biskup posiadał wieś bez przeszkód \\
\hline
\end{tabular}

Przykładami dowodzenia przez exemplum są za to cuda przytoczone przez Długosza na poparcie wskrzeszenia Piotra. Co ciekawe, są to inne exempla niż te podane przez dominikanina Wincentego w jego dwu żywotach ( VMi 17, 18; VMa II 7) ${ }^{130}$. Pierwszy cud Długoszowy polegać miał na wskrzeszeniu cesarza Trajana (I-II w.) przez papieża Grzegorza Wielkiego (VI-VII w.). Przykład mógł zostać przez Długosza zaczerpnięty z Policraticusa V 8 Jana z Salisbury (XII w.), zwłaszcza że egzemplarz tego dzieła, spisany w latach 30. XV w., był własnością Jakuba z Szadka (ok. 1412-1487),

129 VSt, s. 33

$130 \mathrm{VMi}$, s. 265 n. (wskrzeszenie św. Materna), s. 266 n. (wskrzeszenie córki św. Spirydiona); VMa, s. 378 n. (wskrzeszenie św. Materna). 
współlokatora dziejopisa i jego przyjaciela ${ }^{131}$. W drugim cudzie umieszczonym w Żywocie chodziło o wskrzeszenie głowy Saracena przez biskupa miasta Vienne. Długosz podał, że opis tego cudu pochodzi od Piotra de Palude (XIII-XIV w.) ${ }^{132}$. Już dawniej oceniono, że przykłady Wincentego lepiej niż te Długosza pasują do opowieści piotrawińskiej ${ }^{133}$. Najwyraźniej dziejopis podał jednak własne exempla, by zaznaczyć twórczy (a nie bierny) stosunek do opisywanej materii, a także pokazać erudycję i zasób swoich lektur. K. Krotoski zauważył, że kanonik na tyle sposobów udowadniał prawdziwość cudu piotrawińskiego, ponieważ - wbrew jego własnym słowom ${ }^{134}$ - ten cud nie został uznany przez Stolicę Apostolską podczas kanonizacji biskupa ${ }^{135}$.

Często wykorzystywanym zabiegiem w retoryce była amplifikacja, czyli celowa zmiana objętości i ważności opisywanego przedmiotu ${ }^{136}$. W mowie pochwalnej amplifikacja polegała na powiększeniu albo pomniejszeniu winy lub zasługi opisywanych postaci. Choć formalnie jest ona częścią dowodzenia, pojawiać się może we wszystkich partiach mowy, jak i w innych gatunkach literackich ${ }^{137}$. Wyróżnia się cztery podstawowe środki amplifikacji: congeries, incrementum, comparatio i ratiocinatio - wszystkie one występują w Długoszowym Żywocie.

Congeries polega na nagromadzeniu w jednym miejscu synonimicznych słów lub całych zdań, co służy spotęgowaniu ekspresji wypowiedzi. Dziejopis zastosował ten zabieg, opisując rozwiązłość króla:

postquam itaque Boleslaus Rex Polonorum, cupiditates suas palam solvens, naturae lege contempta, in illicitae libidinis vias et passiones miserabiliter prorumpens, egregia quoque facinora sua in vetitam lasciviam superbiamque non ferendam vertisset ${ }^{138}$.

Istotą incrementum jest powiększenie przez zwiększenie objętości, stopniowanie lub powtórzenie. Częstą jego realizacją jest ułożenie synonimicznych określeń w porządku narastającym. Długosz wykorzystał to w sugestywnym i naturalistycznym wręcz opisie ciała zamordowanego właśnie biskupa:

perierat iam in Stanislao Episcopo humanae conditionis cognitio, et non solum quis fuisset, sed et quid esset, naturae figura erepta, tormentorum et concisionum crudelitate, ne agnosci posset, abstulerat. Iacebat siquidem corpus exanime, confossum, sauciatum, scissum; cervix abscisa, cerebrum divulsum, candida olim membra cruore oblita et luto deformia ${ }^{139}$.

Comparatio to porównanie służące uwypukleniu znaczenia własnej tezy. Niekiedy przybiera ono kolejność a maiore ad minus, gdzie chwalony obiekt (maius) zestawiony jest z przykładem (minus), podkreślając ważność i wyższość tego pierwszego. W Żywocie występuje ono w podsumowaniu zasług św. Stanisława:

quis enim non miretur virum beatum, post triennales cineres, Petrum militem suscitasse? Et Boleslai Regis milites, ad mactandum virum Dei ter destinatos, ter detrorsum corruisse? Cum et Lazarus a Christo [...] resuscitatus, tantummodo quatriduanus extiterit, et Iudas Iscariothes cum Iudaeis Iesum Christum [...] comprehensurus, semel tantummodo retrorsum ceciderit ${ }^{140}$.

131 BJ, rkps 483, Policraticus, k. 1r-225v. O pochodzeniu kodeksu informuje nota proweniencyjna umieszczona na oprawie, zob. Catalogus codicum manuscriptorum medii aevi Latinorum, qui in Bibliotheca Jagellonica Cracoviae asservantur, t. 3 , oprac. M. Kowalczyk, A. Kozłowska, M. Markowski, S. Włodek, G. Zathey, M. Zwiercan, Wratislaviae 1984, s. 92-95. Podobną historię można znaleźć też w Złotej legendzie (św. Grzegorz papież, s. 168).

132 Dość podobna historia (tylko o głowie poganina) opowiedziana została w Złotej legendzie (św. Makary, s. 105).

${ }^{133}$ K. Krotoski, Ś. Stanisław biskup, s. 90.

134 VSt, s. 42.

135 K. Krotoski, Ś. Stanisław biskup, s. 87-89.

${ }^{136}$ M. Barłowska, Amplifikacja retoryczna, w: Retoryka, red. M. Barłowska, A. Budzyńska-Daca, P. Wilczek, Warszawa 2009, s. $98-115$.

137 J. Ziomek, Retoryka opisowa, Wrocław 1990, s. 75, 82 n., 117.

138 VSt, s. 47.

139 VSt, s. 67

140 VSt, s. 74. 
Ratiocinatio polega na wyciąganiu wniosków z przytaczanych okoliczności sprawy. W mowie pochwalnej jest to często wychwalanie protagonisty przez podkreślanie wielkości pokonanych przezeń trudności. Odbiorca zmuszony jest wtedy samodzielnie dojść do wniosku, że w takim wypadku wywyższane nie są same przeszkody, ale ten, kto zdołał je pokonać. W hagiografii ratiocinatio realizować można np. przez odpowiednie ukształtowanie opisu codziennego życia świętego ${ }^{141}$. W Żywocie występuje ono np. w opisie lat, które przyszły święty spędził na zagranicznych studiach:

animus insuper et contra avaritiam et carnis mundique petulantiam nitidus et invictus, venerem omnem ac caeci stimulos amoris, quorum difficilis est evitatio, in potestate habuit. Nihil pendens humanam gloriam et passionibus animae viriliter resistens, carnem quoque, ne lascivire inciperet, et calentis aetatis flammas ieiuniorum frigore et carnis maceratione curavit restinguere, custodiens illam ab omni illecebra, et ab omni feminarum contubernio et contagione; perpetuam eligens et custodiens castitatem, et in corpore mortali coelestium aemulatus naturam ${ }^{142}$.

\section{Epilogus}

W oracji epilog (epilogus, peroratio, conclusio) służy przypomnieniu najważniejszych punktów zaprezentowanego wcześniej dowodzenia oraz wywarciu na odbiorcach jak największego wrażenia ${ }^{143}$. O ile bowiem narratio i argumentatio odwołują się do intelektu czytelnika/słuchacza, wstęp i konkluzja służą poruszeniu jego uczuć. Podobnie jak w mowie pochwalnej, celem końcowej partii żywotu jest wzbudzenie entuzjazmu wiernych wobec chwalonej postaci i zachęcenie do podziwiania i naśladowania jej. W przypadku legendy o męczenniku, jak w omawianym utworze, gloryfikacja świętego idzie w parze z potępieniem jego mordercy ${ }^{144}$. Nie każda mowa i nie każdy żywot opatrywane były epilogiem - dotyczyło to tylko prac o silnym retorycznym kolorycie. Długosz umieścił w Żywocie aż dwa epilogi: po części biograficznej i na zakończenie całego żywotu.

Pierwsza konkluzja została zręcznie wkomponowana w ostatni rozdział tractatus I. Pisząc o losach Polski po śmierci św. Stanisława i Bolesława Śmiałego, o utracie statusu królestwa oraz rozbiciu dzielnicowym, Długosz wezwał do kultywowania pamięci o św. Stanisławie ze względu na jego cnoty i męczeństwo, a także dlatego, że za jego sprawą Polska znów stała się królestwem ${ }^{145}$. Ten fragment nie jest przesycony retoryką ani dramatyzmem, ma za to silny wydźwięk narodowo-patriotyczny - krakowski biskup został przedstawiony jako patron państwa wstawiający się u Chrystusa za narodem polskim.

Taką wymowę, dodatkowo pogłębioną, ma także epilog umieszczony pod koniec tractatus III. W tym passusie kanonik podkreślił zasługi Chrystusa wobec Polaków, bo to z Jego woli św. Stanisław narodził się w Polsce, dostąpił wielu łask, poniósł męczeńską śmierć w imię sprawiedliwości i został wyniesiony na ołtarze. W tym „ostatecznym” epilogu, przybierającym formę listu do Sędziwoja, Długosz zastosował typowe dla konkluzji elementy: zaanonsował zakończenie pracy i podkreślił zwięzłość swojego opowiadania oraz to, że starał się w ten sposób spełnić - konwencjonalne - rozkazy maiorum meorum ${ }^{146}$. Na koniec powtórnie dedykował pracę Sędziwojowi w dowód przyjaźni i poprosił go o wstawiennictwo w modlitwach. Dziejopis nie omieszkał też wspomnieć o braku ozdobności oraz marności ukończonego utworu i braku talentu (topos skromności), podkreślił jednak swoje zaangażowanie w pracę i dobre chęci. Aby poruszyć odbiorcę, powtórzył w ogólnym zarysie zasługi św. Stanisława, eksponując niezwykłość jego życia, dramatyzm śmierci i trudy kanonizacji. Wykorzystał przy tym szereg synonimicznych, ekspresyjnych przymiotników i środków stylistycznych ${ }^{147}$. Kanonik próbował

141 P. Nehring, Topika, s. 66.

142 VSt, s. 14

${ }_{143}$ P. Nehring, Topika, s. 114-130; H. Lausberg, Retoryka literacka, s. 262-267.

144 J. Banaszkiewicz, Czarna i biała legenda, s. 353-390.

145 VSt, s. 92: ,per cuius intercessionem et merita reintegratio ipsa provenit, et in futurum creditur plenius proventura".

146 VSt, s. 171 n. (cyt. ze s. 172).

147 Wszystkie przykłady pochodzą z VSt, s. 171: „foeda et horrenda tormenta”, „mirabilem pertulit agonem”, „vitam Angelicam et admirabilem, martyrii ordinem crudelem et horribilem, canonizationis seriem impeditam et difficilem”, „stupenda [...] et memorabilia [...] praeconia". 
poruszyć odbiorców, zarówno przypominając im zasługi św. Stanisława, jak i podkreślając ich (topiczną) niewyrażalność i niepojmowalność.

\section{Figury słów, figury myśli i tropy}

O artystycznym kształcie utworu stanowi także jego szata słowna. Aby nadać dziełu walor literacki, pisarz wykorzystuje rozmaite środki stylistyczne. W terminologii retorycznej używanej w starożytności, a potem przejętej w średniowieczu, określano je mianem figur słów, figur myśli i tropów. Nie istniał kanoniczny „zestaw” figur obu typów i tropów - różni autorzy prac gramatycznych i retorycznych podawali ich krótsze lub dłuższe wykazy ${ }^{148}$. Zastosowanie tych trzech typów środków można wskazać w Długoszowym Żywocie. Podczas ich prezentacji posłużyłam się systematyką Heinricha Lausberga ${ }^{149}$.

Figury słów (figurae verborum) to określone sposoby łączenia wyrazów albo zastępowanie jednej frazy inną dla pełniejszego wyrażenia myśli. Istotny był tu dobór konkretnych wyrazów, ponieważ zmiana słowa w figurze myśli mogła zmienić sens wyrażenia. Figury słów, które D. Turkowska wskazała u Długosza, przedstawiam w poniższej tabeli ${ }^{150}$.

Tabela 3. Figury słów w Żywocie św. Stanisława Jana Długosza

\begin{tabular}{|c|c|c|}
\hline Nazwa figury & Definicja figury & VSt \\
\hline anafora & $\begin{array}{l}\text { powtórzenie tego samego wyrazu } \\
\text { na początku tekstu i kolejnych jego } \\
\text { segmentów }\end{array}$ & $\begin{array}{l}\text { „tunc quidem Pontificum unctione visibili consecratus; sed dudum } \\
\text { Spiritus sancti charismate invisibili uberrime perfusus: tunc in } \\
\text { summum sacerdotium ab hominibus evectus; sed dudum ex } \\
\text { utero matris suae a Christo Domino, qui illum sibi vas electionis } \\
\text { praeviderat futurum, Polonico gregi Pastor praedestinatus" (s. 17) }\end{array}$ \\
\hline asyndeton & $\begin{array}{l}\text { bezspójnikowe połączenie zdań lub } \\
\text { ich części }\end{array}$ & $\begin{array}{l}\text { "permisit illum invadi, excerebrari, } \underline{\text { mutilari }}, \underline{\text { concidi }}, \text { omnia membra } \\
\underline{\text { scindi, }} \text { disiici, feris devoranda exponi” (s. } 75)\end{array}$ \\
\hline $\begin{array}{l}\text { enumeratio } \\
\text { (accumulatio) }\end{array}$ & $\begin{array}{l}\text { wielokrotne powtórzenie tego samego } \\
\text { słowa lub słów bliskoznacznych, speł- } \\
\text { niających podobną funkcję lub podob- } \\
\text { nie brzmiących }\end{array}$ & 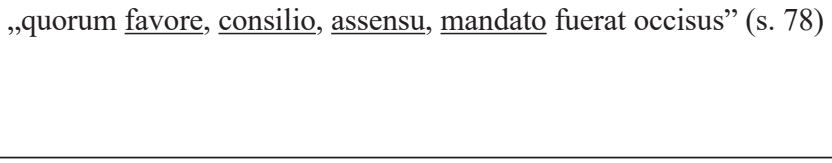 \\
\hline homoioteleuton & $\begin{array}{l}\text { upodobnienie zakończeń kolejno } \\
\text { następujących po sobie słów }\end{array}$ & $\begin{array}{l}\text { "et vitae sanctitas, et martyrii raritas, et prodigiorum multipli- } \\
\text { citas" (s. 137) }\end{array}$ \\
\hline hyperbaton & $\begin{array}{l}\text { rozdzielenie dwu wyrazów (najczę- } \\
\text { ściej rzeczownika i przymiotnika) } \\
\text { przez wstawienie między nie takiej } \\
\text { części zdania, która powinna stać } \\
\text { w innym miejscu }\end{array}$ & $\begin{array}{l}\text { (wskazane tylko w Żywocie bł. Kingi), ,infusam a Deo coeli } \\
\text { naturam" (J. Długosz, Vita beatae Kunegundis, w: tenże, Opera, } \\
\text { t. 1, wyd. I. Polkowski, Ż. Pauli, Cracoviae 1887, s. 186); „, dulces } \\
\text { cum Sponso suo coelesti sermones" (tamże, s. 219) }\end{array}$ \\
\hline klimaks (gradatio) & stopniowanie & $\begin{array}{l}\text { „tam claro, tam sancto, tam glorificato [...] praesuli” (s. 84); „sin- } \\
\text { guli illum [...] oderant, vitabant, fugiebant, detestabantur” (s. 85) }\end{array}$ \\
\hline $\begin{array}{l}\text { paronomazja } \\
\text { (annominatio) }\end{array}$ & $\begin{array}{l}\text { zestawienie brzmieniowo podobnych } \\
\text { wyrazów }\end{array}$ & $\begin{array}{l}\text { „vitam omnem suam omnesque mores atque actiones arctiori } \\
\text { custodia et castigatione, arctioribus quoque continentiae vinculis } \\
\text { constrinxit" (s. 18); ,pro reprobato et reprobando Rege” (s. 57) }\end{array}$ \\
\hline polyptoton & $\begin{array}{l}\text { powtórzenie tego samego słowa } \\
\text { w różnych formach, np. w różnych } \\
\text { przypadkach }\end{array}$ & $\begin{array}{l}\text { "Christum victorem victor secutus ad coelum” (s. 69); „ut sanguis } \\
\text { sanguinem tangereret et } \underline{\text { abyssus }} \underline{\text { abyssum invocaret” (s. 66) }}\end{array}$ \\
\hline
\end{tabular}

Źródło: D. Turkowska, Etudes sur la langue et sur le style de Jean Dlugosz, Kraków 1973, s. 68-80; wskazanie anafory pochodzi od autorki niniejszej pracy; definicje figur słów za: J. Ziomek, Retoryka opisowa, Wrocław 1990; Retoryka, red. M. Barłowska, A. Budzyńska-Daca, P. Wilczek, Warszawa 2009.

148 B. Otwinowska, Tropy, w: Słownik literatury staropolskiej: średniowiecze, renesans, barok, red. T. Michałowska, przy udziale B. Otwinowskiej, E. Sarnowskiej-Temeriusz, Wrocław 2002, s. 999; T. Michałowska, Średniowieczna teoria literatury $w$ Polsce. Rekonesans, Wrocław 2007, s. 265 n., 273 n.

149 H. Lausberg, Retoryka literacka; zob. też J. Ziomek, Retoryka opisowa, s. 202-205.

${ }^{150}$ Podział zaproponowany przez D. Turkowską jest zgodny z podziałem przedstawionym przez H. Lausberga. 
Za to figury myśli (figurae sententiarum) polegają na takim budowaniu wypowiedzi, aby odróżniała się ona od zwykłej mowy. Podobnie jak w przypadku figur słów, celem figur myśli jest dosadniejsze wyrażenie pewnych treści. O ile zmiana wyrazu w figurach słów pociągała za sobą modyfikację ich sensu, w figurach myśli mimo zmiany słowa wymowa wyrażenia pozostawała taka sama. Poniższa tabela przedstawia figury myśli obecne w Żywocie.

Tabela 4. Figury myśli w Żywocie św. Stanistawa Jana Długosza (znalezione przez autorkę)

\begin{tabular}{|c|c|c|}
\hline Nazwa figury & Definicja figury & $V S t$ \\
\hline aetiologia & $\begin{array}{l}\text { dołączenie dodatkowego argumentu } \\
\text { „z przyczyny” }\end{array}$ & $\begin{array}{l}\text { "Sanctae memoriae Stanislaus [...], cui ab incunabulis fidei et } \\
\text { religionis inerat vigor, vitae merito dudum Martyr, velut electus } \\
\text { aries ex magno grege assumptus" (s. 68) }\end{array}$ \\
\hline apostrofa & $\begin{array}{l}\text { bezpośredni zwrot do adresata, ale } \\
\text { innego niż ten, do którego skierowana } \\
\text { jest mowa }\end{array}$ & „quis furor? [...] Quis ausus eam in vobis dementiam peperit” (s. 40) \\
\hline $\begin{array}{l}\text { concessio } \\
\text { (epitrope) }\end{array}$ & $\begin{array}{l}\text { dopuszczenie argumentów strony prze- } \\
\text { ciwnej, po to, aby później je obalić }\end{array}$ & $\begin{array}{l}\text { „novi, fateor, tui culminis eminentiam, a singulis tuis subditis, } \\
\text { a me quoque et colendam et honorandam esse. [...] Nihil est } \\
\text { itaque quod de me iuste queri possis" (s. 31) }\end{array}$ \\
\hline correctio & $\begin{array}{l}\text { poprawienie własnej odpowiedzi dla } \\
\text { wzmocnienia argumentu }\end{array}$ & $\begin{array}{l}\text { „et admirantibus tam audacis animi, vel ut verius loquar, tam } \\
\text { perfectae fidei virtutem” (s. 36) }\end{array}$ \\
\hline $\begin{array}{l}\text { hypotypoza } \\
\text { (evidentia) }\end{array}$ & sugestywny opis & $\begin{array}{l}\text { „iacebat siquidem corpus exanime, confossum, sauciatum, scissum; } \\
\text { cervix abscisa, cerebrum divulsum, candida olim membra cruore } \\
\text { oblita et luto deformia” (s. 67) }\end{array}$ \\
\hline exclamatio & wykrzyknienie & „,ingemisce itaque o Rex” (s. 30) \\
\hline expolitio & $\begin{array}{l}\text { przedstawienie tej samej myśli róż- } \\
\text { nymi, synonimicznymi lub blisko- } \\
\text { znacznymi, środkami językowymi }\end{array}$ & $\begin{array}{l}\text { „naturae ordine transmutato et perverso, naturae quoque indul- } \\
\text { gentia praeterita" (s. 51) }\end{array}$ \\
\hline $\begin{array}{l}\text { prozopopeja } \\
\text { (fictio personae) }\end{array}$ & $\begin{array}{l}\text { przytoczenie pozornej wypowiedzi } \\
\text { tego, kto nie może zabrać głosu (np. } \\
\text { obiektu nieożywionego, personifikacji } \\
\text { emocji czy pojęcia) }\end{array}$ & $\begin{array}{l}\text {,(o Kościele krakowskim) flebat propter viduationem, quod [...] } \\
\text { sponsum sibi dolebat ablatum: gemebatque et in gemitu suo ac } \\
\text { suspiriis per singulas noctes lectum lacrymis rigabat, erantque } \\
\text { iuges lacrymae in maxillis eius" (s. 70) }\end{array}$ \\
\hline finitio & ustalenie pojęć i terminów & $\begin{array}{l}\text { "nemo illum aut spiritum aut phantasma esse existimet; veri et } \\
\text { vivi hominis carnem, ossa, visum et quoslibet sensus habentis, } \\
\text { haec est effigies et imago, quod faciliter et in promptu a quolibet } \\
\text { addubitante poterit convinci” (s. } 39 \text { ) }\end{array}$ \\
\hline $\begin{array}{l}\text { parenteza } \\
\text { (interpositio) }\end{array}$ & zdanie wtrącone & $\begin{array}{l}\text { „existimantibus illis, ut erat, Episcopum Stanislaum parum possibi- } \\
\text { lem rem et difficillimam, pro certa et comperta, spopondisse” (s. 36) }\end{array}$ \\
\hline interrogatio & $\begin{array}{l}\text { postawienie pytania, choć odpowiedź } \\
\text { jest dobrze znana }\end{array}$ & $\begin{array}{l}\text {,age, si tu, omnium nostrum Rex et summi Regis in terris imago, } \\
\text { in haec tam obscoena vitia provolveris; quem subditorum tuorum } \\
\text { pigebit ea non sectari? Cum haec sit populorum omnium natura, ut } \\
\text { quicquid a Praesidibus agi viderint, in id sint et ipsi praecipites } \\
\text { et proclivi” (s. } 29 \text { n.) }\end{array}$ \\
\hline licentia & śmiałe wyrażenie swoich poglądów & $\begin{array}{l}\text { „multiplici }[\ldots] \text { deformitate pensata, sic nec a me }[\ldots] \text { poterit } \\
\text { sileri” (s. } 30)\end{array}$ \\
\hline obsecratio & zaklinanie & $\begin{array}{l}\text { "te deprecor, te moneo, te obtestor, tum per ipsum Deum, cui } \\
\text { omne sordet iniquum, tum per religionem orthodoxam, tum per } \\
\text { decus tuum regium, per denique Regnum tuum Polonicum” (s. 53) }\end{array}$ \\
\hline oxymoron & $\begin{array}{l}\text { zestawienie słów o przeciwnych zna- } \\
\text { czeniach }\end{array}$ & „quod non poteram a vivis testimonium, mutuabo a mortuis" (s. 36) \\
\hline praeparatio & przewidywanie przebiegu sprawy & $\begin{array}{l}\text { „momentaneae insuper tuae voluptati, primum orbitatem et regni } \\
\text { perniciem exterminiumque, deinde perpetuos cruciatus et poenas } \\
\text { non dubites responsura; a terreno primum regno, deinde a coelesti, } \\
\text { nisi resipueris, [...] hereditate excludendus, cum Gomorritis et } \\
\text { Sodomitis in sulphuris iudicandus examine" (s. 53) }\end{array}$ \\
\hline
\end{tabular}




\begin{tabular}{|c|c|c|}
\hline Nazwa figury & Definicja figury & $V S t$ \\
\hline praeteritio & $\begin{array}{l}\text { deklaracja pominięcia niektórych } \\
\text { kwestii }\end{array}$ & $\begin{array}{l}\text { "quamvis }[\ldots] \text { noverim te, o Rex, saluberrima mea monita, tibi } \\
\text { pridem a me paterna caritate ingesta, obturata audisse aure, }[\ldots] \\
\text { gravibus etiam me contumeliis et improperiis insectasse: omnium } \\
\text { tamen illorum facile oblitus" (s. } 51 \text { ) }\end{array}$ \\
\hline gnoma (sententia) & $\begin{array}{l}\text { zdanie uogólniające doświadczenie } \\
\text { lub zalecające jakiś sposób postę- } \\
\text { powania, wypowiadane jako zasada } \\
\text { obowiązująca }\end{array}$ & $\begin{array}{l}\text { „victorem et Martyrem universo orbi, Polonis vero Protomartyrem } \\
\text { et Patronum magnificum te decerno" (s. 70) }\end{array}$ \\
\hline sermocinatio & $\begin{array}{l}\text { fikcjonalne przytoczenie czyjejś wypo- } \\
\text { wiedzi }\end{array}$ & $\begin{array}{l}\text { wszystkie mowy św. Stanisława do króla Bolesława, modlitwa } \\
\text { św. Stanisława przed śmiercią }\end{array}$ \\
\hline similitudo & porównanie & $\begin{array}{l}\text { "quanto lunaris splendor erga solare iubar, et plumbi species } \\
\text { erga auri fulgorem habetur inferior: tantum regia dignitas, si ad } \\
\text { Apostolicam iusta comparatione illam referas" (s. 31) }\end{array}$ \\
\hline subiectio & $\begin{array}{l}\text { fikcja dialogu, stawianie pytania sobie } \\
\text { samemu i udzielanie odpowiedzi }\end{array}$ & $\begin{array}{l}\text { „et, si utriusque ingenue nosse velis efficaciam et virtutem [...]: } \\
\text { tantum regia dignitas, si ad Apostolicam iusta comparatione illam } \\
\text { referas" (s. } 31 \text { ) }\end{array}$ \\
\hline subnexio & $\begin{array}{l}\text { dołączenie do myśli głównej wywodu } \\
\text { ubocznego uzasadnienia }\end{array}$ & $\begin{array}{l}\text { "obscoenam sectaris venerem, non corpus tantummodo et spiri- } \\
\text { tum, sed ipsarum etiam aurarum spiramina foedantem" (s. } 55 \mathrm{n} \text {.) }\end{array}$ \\
\hline
\end{tabular}

Źródło: zestaw figur myśli za: H. Lausberg, Retoryka literacka. Podstawy wiedzy o literaturze, thum., oprac. i wstęp A. Gorzkowski, Bydgoszcz 2002, s. 417-492; J. Ziomek, Retoryka opisowa, Wrocław 1990, s. 204 n.; definicje figur myśli za: tamże; Retoryka, red. M. Barłowska, A. Budzyńska-Daca, P. Wilczek, Warszawa 2009.

Tropami w retoryce nazywa się semantyczne przekształcenia wyrazów, tzn. takie przekształcenia, które naruszają ustabilizowany związek między nazwą rzeczy a tym, co ta nazwa oznacza. W praktyce polega to na zamianie utartych nazw czy wyrażeń na określenia mniej oczywiste oraz na zmianie znaczeń wykorzystywanych słów. Tropem może być zarówno zastąpienie jednego słowa innym, jak i wieloma innymi ${ }^{151}$. Istotą tropów jest nadużywanie (abusio) znaczeń wyrazów, ale przez to, że dokonywano tego zabiegu na mocy licencji poetyckiej, w średniowieczu ich stosowanie uznawano za przejaw kunsztu pisarskiego (abusio cum virtute) - z tego powodu tropy zaliczano do środków cechujących ornatus difficilis. W poniższej tabeli przedstawiłam użycie tropów w Długoszowym Żywocie.

Tabela 5. Tropy w Żywocie św. Stanisława Jana Długosza

\begin{tabular}{|c|c|c|}
\hline Nazwa tropu & Definicja tropu & $V S t$ \\
\hline emfaza (emphasis) & $\begin{array}{l}\text { użycie wyrażenia, które w danym } \\
\text { kontekście znaczy więcej niż w rze- } \\
\text { czywistości }\end{array}$ & $\begin{array}{l}\text { „noli te solum putare Regem, sed hominem” (s. 52); „,mea [...] } \\
\text { vita omnibus in speculo posita est, qui si paulum titubavero aut } \\
\text { reprehensionem meam remisero, turpem fugam iniisse, turpi casu } \\
\text { cecidisse iactabor” (s. } 57 \text { ) }\end{array}$ \\
\hline $\begin{array}{l}\text { hiperbola } \\
\text { (hyperbole) }\end{array}$ & $\begin{array}{l}\text { wyolbrzymienie; opisanie w sposób } \\
\text { przesadny }\end{array}$ & $\begin{array}{l}\text { „et quamvis eius martyrii dignitas multo maior sit, quam vel } \\
\text { a me describi, vel ingenio meo comprehendi possit” (s. 2); „plus } \\
\text { aliquanto crevit quam meum ferret ingenium, nobilius etiam quam } \\
\text { meum sit oneratura” (s. 3); ,ut quo ascendere mea habetudo non } \\
\text { possit, caelesti suffragio adiutus transmigrem” (s. 8); „,solicitabatur } \\
\text { plurimorum gravium virorum ex schola Parisiensi admonitione, } \\
\text { [...] quatenus se Iuris Canonici aut Theologiae Doctoratu insigniri } \\
\text { pateretur” (s. 14); „fiebat ad illum ex universo Poloniae regno } \\
\text { frequens tam ecclesiasticorum quam secularium concursus, vel } \\
\text { erudiri in casibus ambiguis expetentium, vel suis conscientiis } \\
\text { consuli deposcentium” (s. 15); „recordaretur beneficiorum Dei } \\
\text { multiplicium, per quae ab humili sorte ad praesentem gloriam } \\
\text { atque substantiam pervenisset” (s. } 25 \text { ) }\end{array}$ \\
\hline
\end{tabular}

151 J. Ziomek, Retoryka opisowa, s. 159-199; B. Otwinowska, Tropy, s. 998-1002. 


\begin{tabular}{|c|c|c|}
\hline Nazwa tropu & Definicja tropu & $V S t$ \\
\hline litotes & $\begin{array}{l}\text { użycie zaprzeczenia danej cechy, ale } \\
\text { takiego, które nie jest równoznaczne } \\
\text { z antonimem tej cechy }\end{array}$ & $\begin{array}{l}\text { „,noveram insuper munus id a priscis scriptoribus, neque impuden- } \\
\text { ter, neque ineleganter, praeoccupatum fuisse” (s. 5); ,erit fortasse } \\
\text { et non inamoenum, altero scemate Sancti explicare vitam” (s. 7) }\end{array}$ \\
\hline $\begin{array}{l}\text { metafora } \\
\text { (metaphora) }\end{array}$ & $\begin{array}{l}\text { przeniesienie cech jednej rzeczy na } \\
\text { inną na zasadzie podobieństwa }\end{array}$ & $\begin{array}{l}\text { „,animum [...] idque frequenter pene assidua meditatione pectus } \\
\text { decoquebat” (s. 1); ,animo [...] invisceratus meo" (s. 3); „,vivaci } \\
\text { illo tuo, ut sic dixerim, sulphure, si quid incomptum, [...] con- } \\
\text { crema” (s. 3); ,assiduis gradibus ferebatur in praeceps” (s. 24); } \\
\text { „,iter scoenosum, quo graderis, laqueis refertum est, tribulisque } \\
\text { consertum, inexitiabile tibi discrimen [...] addicturum” (s. 30); } \\
\text { „qui virtutum suarum aromata odore gratissimo [...] diffuderat” } \\
\text { (s. 48); „oculos mentis et corporis in nefarias libidinis vetitae } \\
\text { turpitudines defigens” (s. } 48 \text { n.); ,omnem vitiorum tuorum aeru- } \\
\text { ginem concrema” (s. 53) }\end{array}$ \\
\hline $\begin{array}{l}\text { metonimia (meto- } \\
\text { nymia) }\end{array}$ & $\begin{array}{l}\text { opisywanie zjawiska przez odwołanie } \\
\text { się do innego zjawiska, pozostają- } \\
\text { cego z nim w zauważalnej zależności } \\
\text { (np. metonimia autora, gdy mówi się } \\
\text { „czytam Długosza” zamiast „czytam } \\
\text { dzieło Długosza”) }\end{array}$ & $\begin{array}{l}\text { „felicemque dixere patriam, quae tam celebrem infantem [...] } \\
\text { produxisset; felices parentes, quorum semine satus errat” (s. 11); } \\
\text { „maiori veneratione frequentari coeptus est; dum illum fidelium } \\
\text { devotio [...] superaedificata [...] ecclesia" (s. 22) }\end{array}$ \\
\hline $\begin{array}{l}\text { peryfraza (peri- } \\
\text { phrasis) }\end{array}$ & $\begin{array}{l}\text { omówienie wyrazu (zwykle w postaci } \\
\text { przesadnego opisu z nadmiarem okre- } \\
\text { śleń) }\end{array}$ & $\begin{array}{l}\text { „ratus laborem nostrum, etsi non dicendi satiatis et peritis, at } \\
\text { saltem a litterarum sapore ieiunis, suffecturum” (s. 8) }\end{array}$ \\
\hline $\begin{array}{l}\text { synekdocha } \\
\text { (synecdoche) }\end{array}$ & $\begin{array}{l}\text { opisywanie zjawiska przez użycie } \\
\text { nazwy innego zjawiska, zawierającego } \\
\text { je w sobie lub zawierającego się w nim } \\
\text { (pars pro toto i totum pro parte) }\end{array}$ & $\begin{array}{l}\text { „,dudum, virorum illustrium preci et desiderio [...] morem gessis- } \\
\text { sem” (s. 5); „ut [...] iussioni quoque et expectationi respondeam } \\
\text { plurimorum” (s. 6); „qui operum et virtutum a Sanctis editarum } \\
\text { effigiem [...] effecerunt” (s. 7) }\end{array}$ \\
\hline
\end{tabular}

Źródło: zestaw tropów za: H. Lausberg, Retoryka literacka. Podstawy wiedzy o literaturze, tłum., oprac. i wstęp A. Gorzkowski, Bydgoszcz 2002, s. 313-343; definicje tropów za: J. Ziomek, Retoryka opisowa, Wrocław 1990; Retoryka, red. M. Barłowska, A. Budzyńska-Daca, P. Wilczek, Warszawa 2009.

Większość zastosowanych w Żywocie tropów służy urozmaiceniu języka utworu oraz wprowadzeniu podniosłego tonu opowiadania i wzmożeniu dramaturgii. Szczególnie często występują metafory i hiperbole, które posłużyły Długoszowi do podkreślenia wyjątkowości św. Stanisława, doniosłości zdarzeń, w których miał uczestniczyć ten święty, oraz wielkości czynów, które miał zdziałać. Spośród wyróżnionych przez H. Lausberga tropów, jak się zdaje, w omawianym dziele nie występuje antonomazja, czyli użycie imienia własnego postaci fikcyjnej lub rzeczywistej dla oznaczenia powszechnie znanej i wyrazistej cechy (ale D. Turkowska wskazała jej wykorzystanie w Żywocie bt. Kingi ${ }^{152}$ ). W Żywocie św. Stanisława najwyraźniej nie pojawia się też ironia (ani jej odmiana - sarkazm), polegająca na wykorzystywaniu niezgodności w literalnym i ukrytym sensie wypowiedzi i służąca wyrażeniu pogardy czy wyśmianiu. Zapewne wynika to stąd, że ironia to trop, którego dostrzeżenie i odczytanie zależy od odbiorcy dzieła. Z kolei w dziele hagiograficznym, w którym przekaz musiał być dla odbiorcy jasny, nie było miejsca na interpretacyjne dwuznaczności ${ }^{153}$.

Częste stosowanie w Żywocie św. Stanisława określonych tropów i unikanie innych jest więc związane z gatunkiem literackim, jaki reprezentuje przedmiot badania. Licznie występują w dziele zwłaszcza te tropy, które pozwalają wyrazić treść w wyszukany sposób. Jednocześnie użycie tropów i figur związane było z obranym przez pisarza stylem wypowiedzi.

152 D. Turkowska, Etudes, s. 81; J. Długosz, Vita beatae Kunegundis, s. 240, 246.

153 Gdy Długosz krytykował króla Bolesława, jego doradców bądź współczesne sobie duchowieństwo, zawsze robił to wprost, kontrastując postawy naganne z tymi godnymi naśladowania; por. np. VSt, s. 19 n., 24. 


\section{Style: niski, średni i wysoki}

List dedykacyjny do Żywotu św. Stanisława oraz zamykający edycję list Sędziwoja do Długosza mają charakter metaliteracki. Kanonik wielokrotnie podkreślił w nim troskę o formę i język dzieła, powołując się także na autorytet Seneki ${ }^{154}$. Tylko co dla XV-wiecznych duchownych znaczyły „kunszt” i ,artyzm” literatury, a zwłaszcza dzieła hagiograficznego?

Wedle Sędziwoja i Długosza żywot powinien być napisany „dokładnie” (accurate) ${ }^{155}$, „szczegółowo” (exactissime), nie „urywkowo” (truncate), a zatem „obszernie” (cumulate), ale i nie „rozwlekle” (minus terse). Zgromadzenie takich cech miało dawać wrażenie „kompletności” (plene). Tym, o co należało także zabiegać, było „prawdopodobieństwo” (probabilitas) narracji. Wszystko miało się składać na „prawdziwość” (veritas) dzieła, rozumianą jako taki opis wydarzeń, aby - jak mi się zdaje - potrafiły one „przekonać” (persuadere), że opowiedziane zdarzenia naprawdę mogły mieć miejsce. Żywot powinien być ,przyjemny w odbiorze” (mulcere animos audientium) i skomponowany „w sposób uporządkowany” (concinne), a zatem skreślony „umiejętnie” (artificiose), „starannie” (culte) i nie „niejasno” (nubilose). Co do stylu, utwór powinien być napisany z zachowaniem „rozmaitości ujęć" (varietas tegminis), ale nie „przesadnie” (superflue). Styl nie powinien być „oziębły” (tepidus), „,suchy” (arens) ani „prosty” (simplex), tylko cechujący się „świeżością” (viror) i „soczystością” (ubertas), nie „płaski” (tu: parvus) i „bez treści” (ieiunus), lecz „wyrazisty” (tu: nitidus) i „ozdobny” (decorus, fucatus). Słowa powinny być „właściwie dobrane” (exquisitior venustas eloquii) i „wyszukane” (rarus). Utwór nie powinien być „niewygładzony” (rudis), tylko „doskonale wykończony” (tu: cogitatus), a jego język i styl winien sprawiać wrażenie „odpowiednio dostojnego" (tu: vitae [...] et gestorum mirificam praestantiam pari verborum exaequare venustate), „wybitnego” (excellens) i „wyrobionego” (politus), adekwatnie do „wzniosłości” (maiestas) tematu.

Mimo że Długosz miał niskie mniemanie o swoich umiejętnościach pisarskich - częściowo konwencjonalne, ale po części chyba szczere ${ }^{156}$ - Sędziwój skomplementował jego dzieło ${ }^{157}$. Nie poprawiając go i uznając swoją małość wobec biskupów, doktorów i magistrów teologii, adresat niejako „zwolnił się" z odpowiedzialności cenzorskiej, którą kanonik chciał go obarczyć. Umiejętności literackie, które Długosz przypisał prepozytowi, nie były jednak tylko kurtuazyjnymi pochlebstwami. Sędziwój był bowiem wytrawnym stylistą, zwracał uwagę na formę dzieła pisanego i znał zasady ars dictaminis, czyli kunsztownego pisania dzieł prozatorskich ${ }^{158}$.

Reguły dyktamenu nakazywały stosowanie określonego stylu w zależności od opisywanej materii. W odpowiedzi na list dedykacyjny Długosza Sędziwój dał wyraz znajomości teorii trzech stylów, opisał ją i pochwalił dziejopisa za jej zastosowanie w Żywocie ${ }^{159}$. Na podkreślenie zasługuje, że chcąc odnieść się do teorii wymowy, powołał się właśnie na tria genera dicendi, posiadające antyczną proweniencję, a nie na powstałą w średniowieczu dystynkcję na ornatus facilis ('łatwa ozdobność') i ornatus difficilis ('trudna ozdobność') ${ }^{160}$. Sędziwój w pierwszej kolejności scharakteryzował genus humile jako

154 VSt, s. 6: „suadet enim noster Seneca, dum res proferuntur eximiae, earum quoque maiestati cultum sermonis adiungi”.

155 Polskie i łacińskie pojęcia źródłowe zaczerpnęłam z prologu do Żywotu, listu dedykacyjnego oraz listu Sędziwoja do Długosza; VSt, s. 1-4, 5-8, 172-177; Życie św. Stanisława, s. 11-13, 14-16, 175-180.

156 D. Turkowska, Etudes, s. 68 n.

157 Pozytywną opinię o stylu Żywotu św. Stanisława przekazał też autor Żywotu Długosza. Vita Ioannis Dlugosch, s. 57: „,scripsit [...] vitas, beati Stanislai et virginis Kunegundae, historiamque perpetuam Polonorum, stilo mundissimo et magnifico". Żywotopisarz wspomniał tylko o tych pracach, które mają zdecydowanie literacki charakter (oba żywoty i Roczniki).

158 J. Wiesiołowski, Sędziwój z Czechła (1410-1476). Studium z dziejów kultury umysłowej Wielkopolski, St. Źródł., 9, 1964, s. 101; J. Domański, Scholastyka i początki humanizmu w myśli polskiej XV wieku, Warszawa 2011, s. 151-153.

159 VSt, s. 176 n. O zainteresowaniu Długosza teorią trzech stylów świadczyć może prawdopodobnie jego własnoręczna nota De tribus stilis w rękopisie BJ 444 (k. 10v) przy Epistolae familiares Francesca Petrarki (XIII 5, inc. Flebilem ridiculamque rem audies) przy fragmencie: „tres equidem stilos autore Tullio scimus, quos ipse »figuras « vocat: grandiloquum, quem »gravem« appellat, moderatum, quem »mediocrem« vocat, atque humilem, quem »extenuatum« dicit", zob. Catalogus codicum manuscriptorum medii aevi Latinorum, qui in Bibliotheca Jagellonica Cracoviae asservantur, t. 2, oprac. M. Kowalczyk, M. Markowski, G. Zathey, M. Zwiercan, Wratislaviae 1982, s. 346.

160 T. Michałowska, Średniowieczna teoria literatury w Polsce. Rekonesans, s. 173 n. 
ten styl, który „zasadza się na pospolitym mówieniu prawdy” („communi sermone veritatis incendit”). Drugi styl, genus mediocre, który „ani się wielkością nie nadyma, ani płaskością nie poniża, lecz między obojgiem postawiony, przestaje na własnej piękności” („nec magnitudine tumescit, nec parvitate tenuatur, sed inter utrumque positum propria venustate ditatur”). Trzeci styl, genus grande, jest „najwyższy” (summum) i „unosi się głębokimi dowodami i rozumowaniami najmocniejszymi” (,persuasionibus altis et rationibus summis elevatur") ${ }^{161}$. Co więcej, Sędziwój wskazał, w których miejscach Żywotu zastosowano dany styl:

hoc triplici veritatis funiculo, qui difficulter rumpitur, ipsum scriptioma libelli de Vita beatissimi Stanislai per te textum est fortissime. Humili siquidem in ipsius sacratissimi Patris conceptione, nativitate, conversatione morum, et per totam eius vitam procedit verissime: unde virtutibus in medio consistentibus, martyrii victoria ditatus, proinde perenni gloria in coelesti curia et in militante Ecclesia per varia suae sanctitatis miracula est sublimatus ${ }^{162}$.

Styl niski (genus humile) służył w retoryce efektywnemu przekazywaniu informacji, dlatego stosowano go w narratio i argumentatio podczas opowiadania zdarzeń i prezentowania dowodów oraz argumentów; sumarycznie można ująć, że jego cel to docere. Długosz użył go podczas opowiadania wczesnych lat życia św. Stanisława. Styl ten cechuje się jasnością (claritas), poprawnością (puritas) i zrozumiałością (diluciditas), stąd nie ma w nim okresów retorycznych, przeważają zdania zbudowane współrzędnie, stosunkowo niewiele tam środków stylistycznych i retorycznych amplifikacji ${ }^{163}$. Styl ten nie jest jednak zupełnie pozbawiony kunsztu literackiego. Stosując go, autor powinien oszczędnie wykorzystywać figury słów i myśli, a z tropów stosować tylko określony typ metafory ${ }^{164}$.

Genus mediocre (medium) jest stylem o wyraźniejszym zabarwieniu retorycznym. Spełnia funkcję delectare i w mowach używano go, by sprawić publiczności przyjemność, a częściowo także, aby zdobyć jej sympatię. W omawianym żywocie ten styl zastosowano w opisie początków pontyfikatu św. Stanisława. Zdania w tej części dzieła również mają budowę współrzędną, ale znaczna liczba rzeczowników i imiesłowów nadaje im wrażenie wykwintności. Występuje także chiazmatyczny szyk zdania, polegający na odwróceniu symetrii dwóch całostek składniowych (jak w Mt 19,30: „multi autem erunt primi novissimi et novissimi primi”"165). Używa się w nim figur słów, figur myśli i tropów ${ }^{166}$.

Genus grande (sublime, vehemens) to styl najbardziej spośród tych trzech wyszukany. Służy poruszeniu odbiorców i wzbudzeniu w nich silnych uczuć (movere). W oracjach stosowano go dla przekonania odbiorców do swoich racji i do manipulacji publicznością. Dopuszczano w nim wykorzystanie wszystkich dostępnych środków retorycznych. Odpowiednie były w nim apostrofy, wykrzyknienia oraz pytania retoryczne wzmagające dramatyzm i powagę sytuacji ${ }^{167}$. Współczesnemu, ale i nowożytnemu czytelnikowi mógł on wydawać się nienaturalny, przesadny i pretensjonalny, jednak w średniowieczu jego bogactwo i rozmach uważano za szczytowe osiągnięcie literackie ${ }^{168}$. Również Długosz w Żywocie św. Stanisława spróbował swoich sił w tej manierze, opisując konflikt św. Stanisława z królem Bolesławem. Dla osiągnięcia maksymalnego patosu oraz ekstremalnego napięcia wykorzystał fikcyjne mowy i wypowiedzi w oratio obliqua. Wiele z nich to długie i rozbudowane zdania o strukturze podrzędnej, które przeplatane są zdaniami krótkimi i ekspresywnymi. W opisie kluczowej sceny Żywotu, śmierci krakowskiego biskupa, zdania główne są rozwinięte do granic możliwości i jakby przeciążone uzależnionymi od nich zdaniami podrzędnymi. W tej partii dzieła kanonik wykorzystał też nawiązania

${ }^{161}$ Cytaty dotyczące stylów pochodzą z: Życie św. Stanisława, s. 179; VSt, s. 176.

162 VSt, s. $176 \mathrm{n}$.

163 D. Turkowska, Etudes, s. 26.

164 T. Michałowska, Stosowność, w: Stownik literatury staropolskiej, s. 890; taż, Średniowieczna teoria literatury w Polsce. Rekonesans, s. 253 n.

165 D. Turkowska, Etudes, s. 26 n.; Biblia sacra iuxta Vulgatam versionem, red. R. Weber, R. Gryson, Stuttgart 1994, s. 1556.

166 T. Michałowska, Stosowność, s. 890; taż, Średniowieczna teoria literatury w Polsce. Rekonesans, s. 254.

167 Taż, Stosowność, s. 890; taż, Średniowieczna teoria literatury w Polsce. Rekonesans, s. 254.

168 M. Plezia, Retoryka mistrza Wincentego, St. Źródł., 20, 1976, s. 88 n. 
biblijne i rozmaite środki amplifikacji retorycznej: eksklamacje, pytania retoryczne, zwroty paralelne i antytetyczne, metafory, rozbudowane porównania, gry słów wzmocnione efektami brzmieniowymi ${ }^{169}$.

Tabela 6. Zabiegi literackie w jednym wybranym zdaniu Żywotu św. Stanisława Jana Długosza (wyróżnienia i oznaczenia liczbowe pochodzą od autorki)

\begin{tabular}{|c|c|}
\hline VSt (jedno zdanie, s. 62) & Zastosowane zabiegi literackie \\
\hline „Destinatus sorti suae [1.] Boleslaus Rex, $\underline{\text { nullis }} \underline{\text { sanis }}$ & 1. sorti suae - aliteracja (fig. sł.) \\
\hline consiliis, nullis persuc & 2. nullis $(3 \mathrm{x})$ - powtórzenie (fig. sł.) \\
\hline roribus [3.], a ne & 3. sanis consiliis $[\ldots]$ persuasionibus $[\ldots]$ terroribus - klimaks (fig. sł.) \\
\hline inferenda poterat abdu & 4. strona bierna - podkreślenie zatwardziałości króla (gdyby zasto- \\
\hline primum ardore, $\mathrm{d}$ & \\
\hline suggestu [6.] stir & rady odwieść króla c \\
\hline caedem & 5. vel potius - corr \\
\hline $\begin{array}{l}\text { furor }[8 .] \text { illius, atque ultionis de } \\
\text { mam rectuans, rationem }[9 .] \mathrm{cl}\end{array}$ & $\begin{array}{l}\text { 6. inconsulto iracundiae }[\ldots] \text { ardore, }[\ldots] \text { furia }[\ldots] \text { daemoniaco } \\
\text { suggestu - klimaks (fig. sł.) }\end{array}$ \\
\hline suo faventibus $[\overline{10}$ & 7. impiam et nefariam - enumeratio (słowa bliskoznaczne) (fig. sł.) \\
\hline habere coepit: et $\mathrm{q}$ & 8. saeviorque $[\ldots]$ furor -1 \\
\hline ri ani- & 9. rec \\
\hline mad & 10. $m i$ \\
\hline nefar & 11. -vir-, -ver- - paronomazja (człony brzmiące podobnie) (fig. sł.) \\
\hline interitum [12.] $\underline{\mathrm{su}}$ & 12. in interitum $-\mathrm{a}$ \\
\hline contra suum vibrandum susceperat inimicum' & 13. sui sponsi - aliteracja (fig. st.) \\
\hline
\end{tabular}

\section{Technika narracji}

Artystycznym środkiem wyrazu jest także sposób prowadzenia narracji. W zgodzie z uzusem hagiograficznym w Żywocie św. Stanisława zastosowano układ chronologiczny (ordo naturalis). Opowieść Długosza jest dynamiczna i plastyczna, bogata w szczegóły i anegdoty. W ten sposób, realizując moralizatorski cel (docere) w poruszający sposób (movere), dziejopis starał się nadać utworowi walor ludyczny (delectare). Praktyka ta zgodna jest z tendencjami obecnymi w późnośredniowiecznych utworach kronikarskich ${ }^{170}$.

Wyraźną dominantą kompozycyjną Żywotu św. Stanisława jest ukazanie stopniowej eskalacji konfliktu krakowskiego biskupa i króla Bolesława. Treść dzieła została uszeregowana w taki sposób, by wydobyć dramatyzm całej historii, której punktem kulminacyjnym jest męczeńska śmierć biskupa, zrośnięcie się jego ciała oraz wstąpienie do nieba i włączenie przez Chrystusa do grona świętych. Wszystko, co dzieje się przedtem, ma służyć zbudowaniu napięcia w tej części dzieła (odzwierciedla to także stylistyka Żywotu; zob. wyżej: „Style: niski, średni i wysoki”).

Na podkreślenie zasługuje inwencja Długosza w zakresie konstrukcji opowiadania. Dysponując głównie faktami i obrazami z życia św. Stanisława (bardziej rozbudowane, fabularne opisy dotyczyły jedynie cudu piotrawińskiego i śmierci biskupa), utkał z nich spójną i dynamicznie rozwijającą się historię całego jego życia, w której czytelnik mógł znaleźć i wytłumaczenie przyczyn konfliktu, i szczegółowy opis przebiegu sporu z objaśnieniem momentów napędzających bieg wydarzeń, i świadectwa tych zdarzeń widoczne w późniejszych czasach. Urozmaicające dzieło anegdoty nie stanowią wyłącznie dodatków do narracji - niektóre z nich wykorzystano jako motor napędowy akcji (np. losy Krystyny z Bużenina) ${ }^{171}$. Własnym dodatkiem Długosza było też przedstawienie psychologicznych motywów działań podejmowanych przez bohaterów oraz - w przypadku króla Bolesława - ich wewnętrznej przemiany. Na tle wcześniejszych dzieł o św. Stanisławie zabiegi zastosowane w omawianym Żywocie stanowią całkowite novum.

169 D. Turkowska, Etudes, s. 27 n.

170 P. Bering, Struktury narracyjne, s. 10, 41, 49 n.

171 Tamże, s. 102. 
O formie utworu literackiego w dużej mierze decyduje obrany typ narracji. Żywot św. Stanisława służy przede wszystkim opowiedzeniu historii sporu biskupa i króla, dlatego w dziele przeważa narracja trzecioosobowa. Narrator pozostaje poza światem przedstawionym i jest wszystkowiedzący (zna m.in. myśli i motywy działania bohaterów oraz zamysły Boga i szatana). Taki typ narracji miał wzbudzić w odbiorcach wrażenie wiarygodności opisywanych zdarzeń ${ }^{172}$. Jednak, w zgodzie z konwencją hagiograficzną, narrator przedstawia w pracy własny punkt widzenia i implikuje go odbiorcom: stosuje wyraźnie nacechowane wyrażenia, wykorzystuje amplifikację retoryczną, ocenia postaci i ich losy ${ }^{173}$.

Niekiedy Długosz wykorzystuje też narrację pierwszoosobową, by urozmaicić tok opowiadania ${ }^{174}$. Wówczas ujawnia, że to on - autor - jest narratorem dzieła. Taka narracja występuje m.in. we wzmiankach o religii chrześcijańskiej. Wówczas kanonik stosuje tzw. „my” inkluzywne, zaliczając do grona wyznawców chrystianizmu siebie i swoich odbiorców. W ten sposób zmniejsza dzielący ich dystans i identyfikuje się z nimi ${ }^{175}$, np.:

illustrata insuper est eo ipso prodigio nostrae Christianae religionis, nostrae iustitiae, nostri cultus atque fidei purissima credulitas; et per partialem unius individui ex mortuis resurrectionem, futurae nostrae resurrectionis, quam fide credula profitemur, praemonstrata sunt trophaea, et Catholica veritas effectu visibili praegustata ${ }^{176}$.

Długosz-narrator nie ukrywa, że żyje w czasach znacznie późniejszych niż te, które opisuje. Z tego względu czuje się w obowiązku objaśniać odbiorcom dawne realia. Podaje dokładne lokalizacje opisywanych miejsc (np. Szczepanowa, Piotrawina), łącznie z ich dawną i współczesną kościelną przynależnością administracyjną. Tłumaczy też XI-wieczne obyczaje (tak jak je sobie wyobraża), np. dawny sposób zawierania umów i przeprowadzania sądów. Podawanie tak szczegółowych informacji służy pokazaniu erudycji autora oraz zaspokojeniu ciekawości odbiorców (związanej także z późnośredniowiecznym zamiłowaniem do szczegółu) ${ }^{177}$. Niekiedy narrator stwierdza, że dane zjawisko trwa także w jego czasach ${ }^{178}$. Poza tym Długosz nie unika obszerniejszych ekskursów na temat teraźniejszości, w których eksponuje swój stosunek do niej. Dotyczy to zwłaszcza krytycznych wypowiedzi pod adresem współczesnego autorowi duchowieństwa, skontrastowanego z idealnym portretem św. Stanisława ${ }^{179}$. Narrator zakłada, że także jego odbiorcy są świadomi tego rozdźwięku lub mogą się o nim przekonać180. Oprócz tego kanonik nie waha się wygłaszać obiegowych opinii na temat władców i ich doradców, nie porównuje ich jednak wprost z bohaterami swoich czasów ${ }^{181}$. Te komentarze ,zbliżają” czytelników do opisywanej historii oraz aktywizują ich przez zachętę do zestawienia postępowania św. Stanisława z działaniami współczesnych duchownych ${ }^{182}$.

Bardzo częste w średniowiecznym piśmiennictwie są metatekstowe zwroty służące delimitacji tekstu - spotkać je można i w omawianym Żywocie, np. na zakończenie opisu dziecięcych lat Stanisława

\footnotetext{
172 Tamże, s. 65.
}

173 Tamże, s. 66, 159. O ile przewidywalne jest, jak Długosz ocenił krakowskiego biskupa i króla Bolesława, ciekawy jest sposób przedstawienia w Żywocie Lamberta Suły, poprzednika św. Stanisława na urzędzie (VSt, s. 14 n.). Długosz napisał wprawdzie, że to ten ordynariusz odpowiedzialny jest za utratę paliusza i degradację Krakowa do rangi biskupstwa, ale poza tym wyrażał się o nim pozytywnie jako o osobie, która dostrzegła potencjał młodego Stanisława i pozyskała go dla krakowskiego Kościoła; por. zdecydowanie mniej pochlebną opinię dziejopisa o Lambercie Sule w: Ann., ks. 3, s. 82 (1060 r.); J. Długosz, Catalogus episcoporum Cracoviensium, s. 387; tenże, Catalogus archiepiscoporum Gnesnensium, w: tenże, Opera, t. 1, s. 339 n.

174 P. Bering, Struktury narracyjne, s. 53.

175 Tamże, s. 56, 65.

176 VSt, s. 42.

177 P. Bering, Struktury narracyjne, s. 10, 119 n.

178 VSt, s. 13, 79 n., 83, 89. W Rocznikach Długosz postrzegał trwanie np. zwyczajów jako łącznika przeszłości z teraźniejszością; zob. M. Rzepiela, Jeszcze o miejscu, s. 57 n., przyp. 20.

179 O nepotyzmie: VSt, s. 20; o strojach duchownych: tamże, s. 19 n.

180 VSt, s. $17 \mathrm{n}$.

181 VSt, s. 56, 61, 77, 85, 89.

182 P. Bering, Struktury narracyjne, s. 83. 
narrator stwierdza: ,haec erant Stanislai rudimenta" 183 . Czasem wplata w tok narracji wyrażenia typu ut praemisimus ${ }^{184}$ albo zapowiada dalszą treść dzieła ${ }^{185}$. Takie wyrażenia wzmacniają spójność tekstu oraz ułatwiają czytelnikowi odbiór utworu. Co więcej, w ten sposób autor przyciąga uwagę czytelnika i skłania go do szukania zapowiedzianego wątku w toku dalszej lektury ${ }^{186}$. Ponadto po ekskursach historycznych czy obyczajowych narrator sygnalizuje przerwanie linearnej narracji i powrót do głównego tematu ${ }^{187}$. Innym sposobem delimitacji tekstu było wprowadzenie datacji zjawiska, które właśnie zostało lub miało być opisane. Im pełniejsza była datacja, tym bardziej - w zamyśle - czytelnik miał skupić się na jej przedmiocie ${ }^{188}$. Ze zrozumiałych względów najbardziej rozbudowana datacja znajduje się po opisie śmierci św. Stanisława.

Narrator Żywotu ujawnia się wtedy, gdy odwołuje się do źródeł, z których korzystał podczas pisania dzieła. Nawiązując do dorobku maiores, autor podkreśla swoją erudycję ${ }^{189}$. Długosz stosuje ten zabieg w prologu, gdzie za wzory podaje żywoty św. Pawła pustelnika, św. Hilariona i św. Pauli autorstwa Hieronima ze Strydonu, żywot św. Marcina z Tours pióra Sulpicjusza Sewera oraz żywot św. Mikołaja w opracowaniu Symeona Metafrastesa i łacińskim przekładzie Leonarda z Wenecji. Odwołuje się tam też do nienazwanych dokładniej prac wielu autorów greckich i łacińskich ${ }^{190}$. Inne źródła ujawnia, podając dwa exempla na poparcie cudu piotrawińskiego: historię o wskrzeszeniu cesarza Trajana przez papieża Grzegorza Wielkiego i o mówiącej czaszce Saracena ${ }^{191}$. Długosz odsyła czytelnika Żywotu także do własnych Roczników jako dzieła, w którym dokładniej naszkicował portret Bolesława Śmiałego ${ }^{192}$.

Dziejopis wypowiada się w pierwszej osobie także dla potwierdzenia prawdziwości opisywanych zdarzeń, również tych znanych z tradycji lokalnej. Powołując się na swoje źródła, pokazuje, że nie jest wszechwiedzący - w ten sposób jeszcze mocniej wzbudza wiarygodność u odbiorców ${ }^{193}$. Robi tak w przypadku podania o Brzeźnicy, gdzie św. Stanisław miał zostać znieważony przez miejscowego szlachcica, ale ostatecznie wybaczył mu jego winy ${ }^{194}$. Narrator podaje, że pamięć tego wypadku nie zatarła się, o czym świadczy to, że i dawniej, i w jego czasach (in diebus quoque nostris) odbywają się pielgrzymki na tzw. Świętą Łąkę koło Brzeźnicy. Innym razem narrator ujawnił się dla zapewnienia o prawdziwości cudu piotrawińskiego ${ }^{195}$. Dziejopis potwierdził słuszność swoich sądów także świadectwem pism, które widział ${ }^{196}$.

Narrator często wypowiada się w pierwszej osobie także wtedy, gdy wyraża własny pogląd na opisywane zdarzenia ${ }^{197}$. Niekiedy eksponuje je w swoim imieniu, niekiedy zaś nadaje im formę opinio

183 VSt, s. 12

184 VSt, s. 37; zob. też tamże, s. 54, 65.

185 VSt, s. 17: ,humanam autem electionem tunc de Stanislao factam ostendit Deus, ut procedente sermone narrabimus, suae congruam voluntati”; zob. też tamże, s. 74.

186 P. Bering, Struktury narracyjne, s. 54, 82, 83, 162.

187 Tamże, s. 32; VSt, s. 20: „sed a narrationis digressus semita, me ipsum revocabo, et ad Stanislaum nostrum, de quo mihi omnis praesens stylus susceptus est, redeo"; zob. też VSt, s. 24, 34, 65.

188 P. Bering, Struktury narracyjne, s. $71 \mathrm{n}$.

189 Tamże, s. 52 n.

190 VSt, s. 7: „pluribusque aliis tam Graecis quam Latinis [...] scriptoribus”; zob. też tamże, s. 74.

191 VSt, s. 44: „legitur” oraz „ut Petrus de Palude scribit”.

192 VSt, s. 24: „sed Regis, quo de nunc agimus, non est institutum singula in utramvis partem exequi facinora, memorans ea ab alio in loco me largius perscripsisse, praesertim cum ad alia assumpti operis exequenda liceat potius invacare negotia". Przywołany ustęp pomaga określić czas powstania tej części Roczników; zob. M. Plezia, Dookoła sprawy, s. 374 n.

193 P. Bering, Struktury narracyjne, s. 51 n., 148.

194 VSt, s. $21 \mathrm{n}$.

195 VSt, s. 42: „quae autem [...] a me narrantur, non in obscuro gesta sunt, sed in publico [...] et in magnae multitudinis tam ecclesiasticorum quam secularium, qui haec nobis tradiderunt, virorum conspectu”. Potem kanonik podał informację o fundacjach Zbigniewa Oleśnickiego w Piotrawinie: murowanym kościele pw. św. Stanisława i murowanej kaplicy z płytą nagrobną rycerza Piotra; zob. Vita Ioannis Dlugosch, s. 37; M. Walczak, Działalność fundacyjna biskupa krakowskiego, kardynała Zbigniewa Oleśnickiego, „Folia Historiae Artium”, 28, 1992, s. 59 n.

196 VSt, s. 139: ,verificari autem et defendi ea res potest, quam scribo, si quis forte illam phantasticam aut commentitiam putet, per originalem litteram, a praedicto Iohanne Gayethano Cardinali Prandothae Episcopo et Capitulo Cracoviensi in pergameno scriptam, per nos frequentius visam et contrectatam, in scriniis Cracoviensis Ecclesiae repositam"; zob. też tamże, s. 90.

197 Poza przytoczonymi dalej przykładami zob. też: VSt, s. 35, 43 n., 46, 50, 65, 69, 73, 77, 82. 
communis $^{198}$. Jest to zwerbalizowane ,ja” autorskie, zwracające uwagę odbiorcy na osobę twórcy ${ }^{199}$. W przypadku Długosza zabieg ten służy przede wszystkim rozważaniom historiozoficznym, np.: „ob id siquidem unicum patricidii in Sanctum Dei scelus, arbitror Deum aversatum gentem Polonicam et Regnum"200 albo:

ego vero cum [...] Regnum Polonicum [...] conspicio: in eam dubitationem compulsus redigor, praevaricationene tantummodo regia, an etiam populi Polonici facinore haec ipsa mala, quae in annos prope ducentos duraverant, accidissent; sed, si verum fateri volumus, et Regis et populi scelus ad inferendam ultionem Divinitatem coegit ${ }^{201}$.

W drugim przykładzie wykorzystano w jednym zdaniu narrację w pierwszej osobie liczby pojedynczej i mnogiej. Zabieg ten jest celowy: najpierw wyrażone zostaje osobiste wahanie narratora-autora, a następująca tuż potem odpowiedź w liczbie mnogiej pokazuje, jakie zdanie Długosz chciał wpoić odbiorcom Żywotu. Użycie w takiej sytuacji pierwszej osoby liczby mnogiej sygnalizuje, jak bardzo autorowi zależało na tej kwestii ${ }^{202}$.

Dla uplastycznienia opowieści i wzmocnienia przekazu Długosz przeplata w Żywocie wypowiedzi w mowie zależnej i niezależnej. Tę technikę narracyjną wykorzystał już wcześniej dominikanin Wincenty. W większości przypadków Długosz zastosował przytoczenia w tych samych miejscach, co jego XIII-wieczny poprzednik ${ }^{203}$. W niektórych fragmentach zamienił obecną w Żywocie większym mowę zależną na niezależną i vice versa ${ }^{204}$. Cytaty w Żywocie Długoszowym są zawsze bardziej rozbudowane niż u Wincentego. Widać, że kanonik stara się wyrazić te same myśli, ale na własny sposób, innymi (bardziej wyszukanymi) słowami. W tekście omawianego Żywotu można jednak dostrzec ślady XIII-wiecznego wzoru. W poniższej tabeli zestawiłam wybrane wystąpienia mowy niezależnej u Długosza i dominikanina Wincentego (podobieństwa zaznaczyłam podkreśleniem).

Tabela 7. Porównanie wybranych wystąpień mowy niezależnej zamieszczonych w Żywocie większym dominikanina Wincentego i Żywocie św. Stanisława Jana Długosza

\begin{tabular}{|c|c|c|}
\hline Opis sytuacji & $V M a$ & $V S t$ \\
\hline $\begin{array}{l}\text { św. Stanisław wskrzesza } \\
\text { Piotra }\end{array}$ & $\begin{array}{l}\text { „In nomine patris et filii et spiritus sancti, surge } \\
\text { Petre, qui dormis, et exurge a mortuis, ut mani- } \\
\text { festetur in te virtus et operacio sancte trinitatis. } \\
\text { Surge [...] et sta in medium, da honorem Deo, } \\
\text { vertitati perhibendo testimonium, ut augeatur } \\
\text { fides credencium et obstruatur os hominum iniqua } \\
\text { loquencium”. (s. 376) }\end{array}$ & $\begin{array}{l}\text { „In nomine Patris, et Filii, et Spiritus Sancti, } \\
\text { et in virtute benedictae et individuae Trinitatis, } \\
\text { iubeo tibi, Petre, ut consurgas de pulvere, exurgas } \\
\text { a mortuis, ferasque veritati, a filiis hominum } \\
\text { prostitutae et desertae, testimonium: quatenus } \\
\text { augeatur fides credentium, et corripiatur improba } \\
\text { temeritas oppugnantium veritatem”. (s. } 38 \text { ) }\end{array}$ \\
\hline $\begin{array}{l}\text { słowa wskrzeszonego } \\
\text { Piotra }\end{array}$ & $\begin{array}{l}\text { "Ego }[\ldots] \text { precibus et meritis beati viri huius } \\
\text { a mortuis sum suscitatus et per voluntatem Dei }\end{array}$ & $\begin{array}{l}\text { „Ego }[\ldots] \text { ad iussionem divinam, et ad preces viri } \\
\text { beati, Stanislai Cracoviensis Episcopi, suscitatus }\end{array}$ \\
\hline
\end{tabular}

198 P. Bering, Struktury narracyjne, s. 67.

199 Tamże, s. 147.

200 VSt, s. 83

201 VSt, s. $91 \mathrm{n}$.

202 P. Bering, Struktury narracyjne, s. 56.

${ }^{203}$ Te same miejsca wystąpienia mowy niezależnej w żywotowej części Żywotu większego i Żywotu Długosza: mowa biskupa na wiecu (VMa, s. 375; VSt, s. 36), modlitwa biskupa przed wskrzeszeniem Piotra (VMa, s. 376; VSt, s. 38), modlitwa biskupa podczas wskrzeszania Piotra (VMa, s. 376; VSt, s. 38), przedstawienie Piotra przez biskupa królowi (VMa, s. 376; VSt, s. 39), świadectwo Piotra (VMa, s. 377; VSt, s. 39 n.), słowa Piotra do krewnych i innych zebranych (częściowo mowa niezależna, częściowo zależna; VMa, s. 377 n.; VSt, s. 40), rozmowa Piotra z biskupem nt. możliwości przedłużenia ziemskiego życia Piotra (VMa, s. 377 n.; VSt, s. 41), łajanie żołnierzy przez króla w kościele (VMa, s. 387; VSt, s. 65).

204 Różnice w użyciu mowy zależnej i niezależnej w żywotowej części Żywotu większego i Żywotu Długosza: wezwanie przez biskupa do modlitw, by zdołać wskrzesić Piotra (mowa niezależna: VMa, s. 375; mowa zależna: VSt, s. 37), upomnienia króla (mowa zależna: VMa, s. 370, 374 n., 379, 386; mowa zależna i niezależna: VSt, s. 25, 29-32, 49-56), modlitwa biskupa przed śmiercią (mowa zależna: VMa, s. 387; mowa niezależna: VSt, s. 63 n.). 


\begin{tabular}{|c|c|c|}
\hline Opis sytuacji & $V M a$ & $V S t$ \\
\hline & 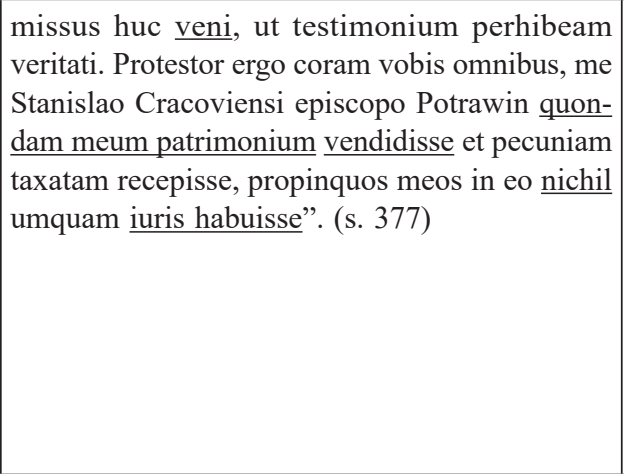 & $\begin{array}{l}\text { ab inferis, ad tuum Tribunal, o Rex, testis et evic- } \\
\text { tor venio; clara et aperta voce profitens et conte- } \\
\text { stans, villam Pyotrawin, quondam patrimonium } \\
\text { meum, me viro beato, Stanislao Cracoviensi } \\
\text { Episcopo, et suae Ecclesiae, legitimo et perpetuo } \\
\text { contractu vendidisse, et argentum, de quo inter } \\
\text { me et virum beatum, Stanislaum Episcopum, } \\
\text { convenerat, ad integrum tulisse; et nepotes meos, } \\
\text { Petrum, Iacobum et Sulislaum, nihil iuris, nihil } \\
\text { proprietatis, nihil devolutionis in villagio illo } \\
\text { habuisse, ac virum Dei Stanislaum Episcopum } \\
\text { per scelus et iniquitatem vexasse". (s. } 39 \text { n.) }\end{array}$ \\
\hline $\begin{array}{l}\text { krytyka Bolesława Śmia- } \\
\text { łego pod adresem żołnie- } \\
\text { rzy, którzy nie byli w sta- } \\
\text { nie dopaść św. Stanisława }\end{array}$ & 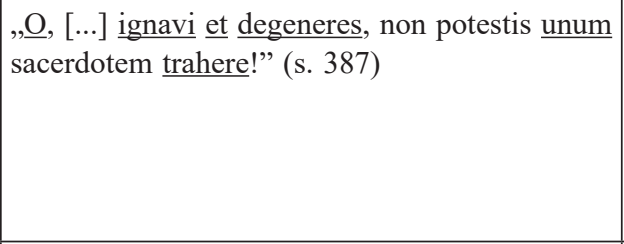 & $\begin{array}{l}\text { „OI Degeneres et ignavi, feminae non viri, pusil- } \\
\text { lanimes non milites, tanto pavore et trepidatione } \\
\text { vos perculsos intueor, ut plures numero unum } \\
\text { presbyterum inermem armati de ecclesia trahere, } \\
\text { et meas graves iniurias in eo ultum iri pertime- } \\
\text { scatis?” (s. 65) }\end{array}$ \\
\hline $\begin{array}{l}\text { objawienie się św. Stani- } \\
\text { sława pobożnej kobiecie } \\
\text { i nakaz translacji jego ciała }\end{array}$ & $\begin{array}{l}\text { „Ego sum Stanislaus Cracoviensis episcopus. } \\
\text { Vade, dic episcopo et canonicis, fratribus meis, } \\
\text { ut corpus meum transferant ad ecclesiam kathe- } \\
\text { dralem, quia hic iaceo sine debito honore et ossa } \\
\underline{\text { mea teguntur pulvere”. (s. } 393 \text { n.) }}\end{array}$ & $\begin{array}{l}\text { „Ego sum [...] Stanislaus Cracoviensis Episcopus, } \\
\text { a te, filia, in hanc diem devote et religiose cultus: } \\
\text { cuius rei merito et gratia te mandatorum meorum } \\
\text { nuntiam iudicavi dignam. Vade itaque, filia, et } \\
\text { successori meo Cracoviensi Episcopo Lamperto } \\
\text { et Canonicis fratribus meis denuntia, ne me et } \\
\underline{\text { corpus meum amplius delitescere, ossaque mea }} \\
\text { in pulverulento tegmine consistere patiantur sub } \\
\text { divo: sed illud dehinc in Cracoviensem Ecclesiam } \\
\text { satagant, quo plus Deo venerationis, mortalibus } \\
\text { vero beneficiorum accedat, transferre”. (s. } 95 \mathrm{n} \text {.) }\end{array}$ \\
\hline $\begin{array}{l}\text { wypowiedzi świątobli- } \\
\text { wych strażników katedry } \\
\text { krakowskiej na temat } \\
\text { objawień św. Stanisława }\end{array}$ & $\begin{array}{l}\text { „Vidimus beatum Stanislaum missarum sollemp- } \\
\text { nia celebrare et circa eum chorum ministrorum } \\
\text { Dei stare et campanas sine nostro et omni humano } \\
\text { ministerio per semet ipsas pulsare”. (s. 394) }\end{array}$ & $\begin{array}{l}\text { „Nihil [...] novum et usurpatum, Patres specta- } \\
\text { biles, aestimetis nos admisisse. Neque enim nos, } \\
\text { neque socii nostri campanas sonavimus: verum } \\
\text { pro certo et comperto vobis exponimus, quod } \\
\text { nostris corporeis vidimus oculis, beatissimum } \\
\text { Stanislaum Episcopum, assistente sibi venerabi- } \\
\text { lium personarum corona et ordine, ad altare maius } \\
\text { astare, rem divinam sub nostro aspectu perficere: } \\
\text { dumque perficeretur, campanas singulas, absque } \\
\text { nostro et omni humano usu atque adminiculo, } \\
\text { per se ipsas pulsare”. (s. } 97 \mathrm{n} \text {.) }\end{array}$ \\
\hline $\begin{array}{l}\text { pewnemu szlachcicowi } \\
\text { ukazuje się zmarły biskup } \\
\text { krakowski Wisław, który } \\
\text { przez cały pontyfikat nie } \\
\text { zajmował się kanonizacją } \\
\text { św. Stanisława }\end{array}$ & $\begin{array}{l}\text { „Non permittor [...] ad ecclesiam venire, quia } \\
\text { tot annis episcopus fui et } \underline{\text { corpus beati Stanislai }} \\
\text { in terre pulvere iacere sustinui; idcirco exspolior } \\
\text { hic indumento pontificali. Vade autem et dic } \\
\text { episcopo Prandote, ut non negligat ossa sancti } \\
\text { de terra elevare”. (s. 396) }\end{array}$ & $\begin{array}{l}\text { Supervacua [...] admiratione percelleris; arceor } \\
\text { enim ab huius, quam olim administrabam, ecc- } \\
\text { lesiae ingressu: quoniam per annos duodecim, } \\
\text { quibus illi praefui, beatissimi corpus Stanislai } \\
\text { Cracoviensis Episcopi iacere in terrae pulvere } \\
\text { permisi, operam insuper meam pro illius cano- } \\
\text { nizatione navare neglexi. En, ut desidiosus et } \\
\text { segnis, et de pontificalibus induviis expolior, } \\
\text { et ab ingressu ecclesiae abigor. Tu vero a me } \\
\text { rogatus, ad Prandotham Cracoviensem Episcopum } \\
\text { modernum et successorem meum immediatum, } \\
\text { perge, meisque verbis illum admone, quatenus } \\
\text { meo deterritus damno, et ossa beatissimi Stanislai } \\
\text { honesto in armario vino lota recondat, et pro } \\
\text { canonizatione eiusdem toto conatu, totoque nisu } \\
\text { promptus et supplex incumbat". (s. 126) }\end{array}$ \\
\hline
\end{tabular}


Charakterystyczne dla twórczości Długosza jest wplatanie w narrację rozbudowanych mów, często wzorowanych na oracjach spotykanych w dziele Liwiusza (I w. p.n.e.-I w. n.e.) ${ }^{205}$. Zjawisko to zauważalne jest także w omawianym żywocie, w którym Długosz umieścił siedem bezpośrednich zwrotów św. Stanisława do Bolesława ${ }^{206}$. Co ciekawe, choć wedle opowiadania kanonika biskup miał pouczać króla podczas rozmowy, wypowiedzi ordynariusza przytoczone są w mowie niezależnej, w rozbudowanych oracjach, za to zdanie monarchy zawsze przywoływane jest lakonicznie i w mowie zależnej. W ten sposób Długosz zasygnalizował sytuację dialogową, de facto nie wprowadzając do dzieła dialogu. Ponadto przez sam kształt narracji kanonik wskazał, która postawa jest według niego słuszna, a zatem którą powinni chwalić bądź ganić odbiorcy Żywotu. Jedynym miejscem, w którym głos oddany jest samemu królowi - i w dziele Wincentego, i Długosza - jest przytoczona wyżej obelga na żołnierzy, służąca negatywnej charakterystyce władcy.

Wspomniane „rozmowy” biskupa z królem cechują się swoistą dynamiką i stanowią określony ciąg przyczynowo-skutkowy. Na początku głównym problemem, jaki dostrzegać miał m.in. św. Stanisław, była rozwiązłość króla - zaradzić miało jej łagodne (jak wielokrotnie podkreślał Długosz) upomnienie udzielone przez krakowskiego biskupa w królewskiej sypialni i bez świadków (przywołane w mowie zależnej) $)^{207}$, zgodnie z ewangelicznymi zaleceniami (Mt 18,15-17208). Bolesław miał wówczas skromnie i przyzwoicie odpowiedzieć, że się poprawi (także w oratio obliqua) ${ }^{209}$. Gdy nie dało to oczekiwanego efektu, św. Stanisław postanowił ponownie pouczyć króla, ale tym razem w obecności służby oraz dostojników świeckich i duchownych (mowa niezależna) ${ }^{210}$. Ta konfrontacja miała wywołać wielką złość Bolesława i poskutkować groźbą, że jeszcze zemści się na biskupie (mowa zależna) ${ }^{211}$. Do pognębienia i ukarania św. Stanisława król chciał wykorzystać sprawę piotrawińską (o czym więcej w dalszej części artykułu). Ostateczne zakończenie sporu po myśli krakowskiego biskupa jeszcze wzmogło wściekłość króla i jego gotowość do otwartej konfrontacji. Wtedy Bolesław z władcy rozwiązłego miał stać się uciążliwym dla wszystkich tyranem, a nawet sodomitą, dlatego św. Stanisław poczuł się w obowiązku interweniować. Najpierw po raz wtóry - i ponownie w mowie zależnej - napomniał króla łagodnie i po ojcowsku ${ }^{212}$. Mimo tego Bolesław miał na te słowa wzbić się w pychę i nie reagować na żadne argumenty (również oratio obliqua) ${ }^{213}$. Wtedy dopiero biskup miał zagrozić królowi - w oratio recta klątwą kościelną oraz mękami piekielnymi, pozbawieniem tronu i zagładą całego królestwa (co stanowi vaticinium ex eventu $)^{214}$. Na te słowa Bolesław miał odpowiedzieć biskupowi, że jeśli ten nie przestanie go upominać, spotka go wczesna zguba (mowa zależna) ${ }^{215}$. Kolejnym i ostatnim etapem konfliktu Stanisława z Bolesławem były już wydarzenia na Skałce. Tam duchowni towarzyszący św. Stanisławowi mieli przestrzegać go przed zbliżającymi się do kościoła oddziałami króla (oratio obliqua) ${ }^{216}$, jednak on był przygotowany na śmierć i ostatnie chwile życia poświęcił modlitwie (mowa niezależna) ${ }^{217}$. Ostatnią wypowiedzią w mowie niezależnej w tractatus I były przytoczone wyżej obelgi wygłoszone przez Bolesława do żołnierzy ${ }^{218}$

${ }^{205}$ T. Sinko, De Dlugossii praefatione „Historiae Polonorum”, w: Studia z dziejów kultury polskiej, red. H. Barycz, J. Hulewicz, Warszawa 1949, s. 109-112, 114-118; W. Madyda, Wzory klasyczne w „Historii Polski” Dlugosza, „Eos”, 49, 1957/1958, nr 2, s. 178-192.

206 Bezpośrednie zwroty biskupa do króla dotyczące sprawy piotrawińskiej: VSt, s. 36, 39. Bezpośrednie zwroty biskupa do króla dotyczące postępowania władcy: tamże, s. 29-32, 51-56.

207 VSt, s. 25.

208 Życie św. Stanistawa, s. 38, przyp. 1.

209 VSt, s. 25.

${ }^{210}$ VSt, s. 29-32.

211 VSt, s. 32.

212 VSt, s. 49 n.

213 VSt, s. 50.

214 VSt, s. 51-54, 56.

215 VSt, s. 56.

216 VSt, s. 63.

217 VSt, s. 63 n.

218 VSt, s. 65. 
Z powyższej charakterystyki widać, jak sprawnie i świadomie Długosz operował mową zależną i niezależną dla podniesienia autorytetu bohatera Żywotu oraz dla umniejszenia postaci króla. Poza samym faktem „oddania głosu” protagoniście dzięki użyciu mowy niezależnej dziejopis mógł silniej oddziałać na swoich czytelników - treści przekazane w mowie bezpośredniej są bowiem łatwiejsze w odbiorze, a dzięki zastosowaniu formy mowy autor mógł wpływać na odbiorców wszystkimi możliwymi metodami retorycznymi i środkami stylistycznymi ${ }^{219}$.

\section{Okresy retoryczne}

Średniowieczna teoria literatury, korzystając z dorobku retoryki antycznej, zalecała układanie wypowiedzi w okresy retoryczne (periody), a w ich obrębie w człony (1. poj.: kolon, membrum) i ucinki (1. poj.: komma[t], incisum ${ }^{220}$. Okres retoryczny to złożone zdanie, którego części składowe tworzą zhierarchizowany i uporządkowany, koniecznie „kolisty”, układ (gr. periodos - 'bieg okrężny’, 'nawrót'). Istotą periodu jest zaintrygowanie odbiorcy i wzmożenie jego ciekawości przez zawieszenie sensu wypowiedzi, po którym następuje dopełnienie myśli i spadek napięcia. Period ma skomplikowaną konstrukcję, ale jego struktura pozostaje przejrzysta dzięki wykorzystaniu różnych współrzędnych i podrzędnych form wyrazu (np. łączna: et lub et ... et, przyzwoleniowa: quamquam, warunkowa: si, względna: is .. qui, korelatywna: quantum ... tantum). Period retoryczny obejmuje całe zdanie i wyraża pełną myśl. Kolon, stanowiący część okresu i wyrażający tylko część myśli, to pojedyncze zdanie pełne pod względem składniowym. Od kommatu różni go to, że ma orzeczenie. Kommat, nie mając orzeczenia, nie tworzy zdania; stanowi on część kolonu.

Poza członami i ucinkami w periodzie wydzielić można dwie zasadnicze części: tzw. poprzednik (protasis) i tzw. następnik (apodosis). Trzeba zaznaczyć, że poprzednik i następnik w okresie retorycznym to nie to samo, co poprzednik i następnik w okresie warunkowym (zdaniu warunkowym). W retoryce protasis i apodosis nie są bowiem jednostkami składniowymi, tylko częściami wypowiedzenia budującymi dramaturgię komunikatu. W poprzedniku zapowiada się temat i buduje się napięcie, którego opadnięcie przeciąga się celowo (retardacja) aż do następnika, gdzie podana zostaje czynność zdania nadrzędnego, przez co następuje zamknięcie myśli. Cechą charakterystyczną okresu retorycznego, odróżniającą go od innych zdań złożonych czy konstrukcyjnie skomplikowanych, jest postawienie zdania podrzędnego przed nadrzędnym lub umieszczenie jednego w obrębie drugiego. Jako że period umożliwia przedstawienie dowolnej kwestii w bardziej wyrazisty sposób, często stosowano go we wstępnych partiach mowy czy dzieła literackiego, by tym łatwiej wprowadzić audytorium w przedmiot sprawy. Wykorzystywano go również do opisywania szczególnie ekspresyjnych partii utworu. W tej drugiej funkcji period pojawia się w Żywocie św. Stanisława Długosza. W formę okresów retorycznych ubrany jest np. poniższy fragment jednej z mów św. Stanisława do króla Bolesława:

cum olim te Rex, plerasque transgressiones tuas et carnales illecebras, quibus maiestatis tuae vehementer obfuscabatur culmen, deponere et thorum tuum loris constringere pudicitiae exhortarer; maxima me ceperat fiducia ex tuae modestae responsionis respectu iniecta, singula, pro quibus a me argutus es, prona emendaturum devotione, et in frugem vitae nitidioris atque pudicae evasurum. Nunc, quod non sine acerbitate spiritus commemoro, video te prioribus malis gravius adiecisse facinus, et impios concubitus, rapta militi Mszczislao consorte, regali gravitate prorsus abiecta, miscuisse; nefandae quoque solvisse viscus libidinis, quam te ego arbitrabar, ut tuo et nostro communi pudori consultum foret, opportune oppressurum. Age, si tu, omnium nostrum Rex et summi Regis in terris imago, in haec tam obscoena vitia provolveris; quem subditorum tuorum

219 P. Bering, Struktury narracyjne, s. 141.

${ }^{220}$ M. Plezia, Kronika Galla na tle historiografii XII wieku, Kraków 1947, s. 104-106; A. Werpachowska, Z dziejów retoryki XVI wieku. Polemika Jakuba Górskiego z Benedyktem Herbestem, Wrocław 1987, s. 30-59; J. Ziomek, Retoryka opisowa, s. 269-288; B. Otwinowska, Okres retoryczny, w: Słownik literatury staropolskiej, s. 594-597; H. Lausberg, Retoryka literacka, s. 495-505; D. Turkowska, Etudes, s. 62-67, pisze o okresach warunkowych formowanych przez Długosza, nie zaś o okresach retorycznych. 
pigebit ea non sectari? Cum haec sit populorum omnium natura, ut quicquid a Praesidibus agi viderint, in id sint et ipsi praecipites et proclivi. Iter scoenosum, quo graderis, laqueis refertum est, tribulisque consertum, inexitiabile tibi discrimen, nisi te revocaveris, addicturum ${ }^{221}$.

Periody często konstruowane są na zasadzie antytezy (wyróżniłam ją podkreśleniem):

annum vitae agens sextum et tricesimum, sola probitate et virtute, solo vitae merito, sola vocatione divina et humana, clarissimam inter Polonicae Ecclesiae Cathedras Sedem, in urbe urbium Polonicarum Cracovia, et Pontificatum sortitus: tunc quidem cleri, populi et omni vulgari voce, Apostolico insuper decreto, destinatus Pontifex; sed morum, sed virtutum, $\underline{\text { sed }}$ iurium et omnium cerimoniarum pontificalium a iuventute peritissimus observator: tunc quidem Pontificum unctione visibili consecratus; sed dudum Spiritus sancti charismate invisibili uberrime perfusus; tunc in summum sacerdotium ab hominibus evectus; sed dudum ex utero matris suae a Christo Domino, qui illum sibi vas electionis praeviderat futurum, Polonico gregi Pastor praedestinatus $^{222}$.

Okres retoryczny zawiera zwykle powtórzenia podkreślające jego wieloczłonową budowę. Dodatkowy efekt brzmieniowy daje kończenie kolonów i kommatów rymami (powtórzenia oznaczyłam podkreśleniem, a rymy pogrubieniem):

nisi enim in coelo inter primores et beatissimos Sanctos viveret, nisi singulari merito et celebri martyrio excelleret, neque corporis sui absque cicatricum nota; neque corporis iam excarnificati fulgor, sole lucentior atque splendidior; neque mirae rutilantiae lampades supra artus concisos refulgentes; neque aquilarum coelestium munimina; neque languidorum ad sui nominis invocationem frequens et assidua medela; neque insolita prodigia, quibus vir vere Apostolicus, vere sanctissimus, a Christo Domino declaratus est, provenissent ${ }^{223}$.

\section{Cursus}

Do zasad dyktamenu należało także komponowanie tekstu wedle zasad cursus ('bieg'). Istotą średniowiecznego cursus, opartego na akcencie wyrazowym, było kończenie zdań i ich poszczególnych członów rytmizowanymi klauzulami tworzonymi z określonych sekwencji sylab akcentowanych i nieakcentowanych ${ }^{224}$. O ile zjawisko to było dość powszechne we wczesnym średniowieczu (do VIII w.), a zwłaszcza w wiekach XI-XIII, w późniejszym okresie zasady cursus, już w pełni ukształtowane i nieulegające zmianom, straciły wyjątkowy wymiar artystyczny ${ }^{225}$. Poza piśmiennictwem pragmatycznym (dyplomy) klauzule rytmiczne wykorzystywano także w prozie artystycznej (kroniki, listy). Humaniści wyraźnie dostrzegali jakościową różnicę pomiędzy średniowieczną ars dictandi (a zatem i cursus) oraz stylem starożytnych prozaików i dążyli do odświeżenia języka i formy pisma. W latach 60. XX w. Gudrun Lindholm postawiła tezę o upadku i odejściu od zasad cursus w pismach humanistycznych ${ }^{226}$. Roland G. Witt wykazał niedawno, że u włoskich autorów XIV- i XV-wiecznych zanik klauzul nie był

221 VSt, s. 29 n.

222 VSt, s. 17.

223 VSt, s. 75 n.

${ }^{224}$ M. Plezia, Kronika Galla, s. 106-108; H. Myśliwiec, Zarys wersyfikacji łacińskiej średniowiecza, w: Poetyka. Zarys encyklopedyczny, dział 3: Wersyfikacja, t. 8: Metryki obcojęzyczne, cz. 1: Metryka grecka i łacińska, red. M. Dłuska, W. Strzelecki, Wrocław 1959, s. 154 n.; L. Arbusow, Colores rhetorici. Eine Auswahl rhetorischer Figuren und Gemeinplätze als Hilfsmittel für akademische Übungen an mittelalterlichen Texten, Göttingen 1963, s. 78 n.; M. Plezia, Transmundus, w: Kultura średniowieczna i staropolska. Studia ofiarowane Aleksandrowi Gieysztorowi w pięćdziesięciolecie pracy naukowej, red. D. Gawinowa i in., Warszawa 1991, s. 163-169.

225 L. Kotyński, Rytmika „Kroniki” Wincentego Kadtubka, „Eos”, 49, 1957/1958, nr 2, s. 169.

${ }^{226}$ G. Lindholm, Studien zum mittellateinischen Prosarhythmus. Seine Entwicklung und sein Abklingen in der Brief literatur Italiens, Stockholm 1963, cyt. za: T. Janson, Prose Rhythm in Medieval Latin from the $9^{\text {th }}$ to the $13^{\text {th }}$ Century, Lund 1975, s. 8; R.G. Witt, In the Footsteps of the Ancients. The Origins of Humanism from Lovato to Bruni, Boston-Leiden 2003, s. 514. 
ani nagły, ani całkowity; badacz podejrzewa jednak, że frekwencja cursus poniżej $60 \% \mathrm{w}$ obrębie dzieła świadczy o tym, że wykorzystanie klauzul nie było tam celowe ${ }^{227}$.

W piśmiennictwie średniowiecznym (Bruno z Kwerfurtu, Gall Anonim, Wincenty Kadłubek, biskup krakowski Mateusz ${ }^{228}$ ), w tym hagiograficznym (XIV-wieczny Żywot bł. Kingi ${ }^{229}$ ), już jakiś czas temu zauważono występowanie cursus. Zabieg ten można zaobserwować także w Długoszowym Żywocie, dlatego zasadne jest podanie dokładniejszych informacji o konstrukcji poszczególnych cursus, a potem o ich realizacji w omawianym dziele.

Już twórcy podręczników teorii dyktamenu wyróżnili i nazwali trzy podstawowe typy cursus (planus, velox i tardus), a XIX-wieczny badacz Wilhelm Meyer dodał do nich jeden dodatkowy typ (trispondaicus). Cursus planus to połączenie słowa $\mathrm{z}$ akcentem paroksytonicznym (padającym na przedostatnią sylabę) z następującym po nim 3-sylabowym słowem o akcencie paroksytonicznym, np. córde currámus ${ }^{230}$. Cursus velox występuje, gdy po słowie z akcentem proparoksytonicznym (spoczywającym na drugiej sylabie od końca) następowało 4-sylabowe słowo paroksytoniczne, np. iúgiter sentiémus. Cursus tardus (durus, ecclesiasticus) jest złożeniem 4-sylabowego proparoksytonicznego słowa i poprzedzającego je słowa o akcencie paroksytonicznym, np. ménte cognóvimus. Typ wyodrębniony przez W. Meyera, cursus trispondaicus, polega na umieszczeniu 4-sylabowego słowa o akcencie paroksytonicznym po 2-sylabowym słowie o akcencie paroksytonicznym. Przykładem takiej klauzuli jest Cycerońskie ésse videátur. We wszystkich typach cursus $\mathrm{w}$ drugim słowie istotna była zatem jego długość (liczba sylab) i akcent wyrazowy, za to w pierwszym słowie ważny był tylko jego akcent. Badacze cursus zauważyli też pewną dowolność, na jaką pozwalali sobie niektórzy średniowieczni autorzy rytmizujący prozę: podział na słowa w obrębie klauzuli mógł być dowolny, bo istotna była jedynie suma sylab (i np. cursus planus to zarówno íllum dedúxit, jak vineam nóstram i néc impetrávi). Klauzule mogły też być złożone $\mathrm{z}$ więcej niż dwu słów (np. cursus velox: vidébunt qui in me spérant), a w ramach zjawiska nazwanego consillabicatio pierwszą sylabę ostatniego słowa kadencji można było zamienić na proklityczną monosylabę, czyli wyraz nieposiadający własnego akcentu i tworzący akcentową całość z następującym po nim słowem akcentowanym (np. cursus tardus: óvis ad víctimam). Poza tym spotyka się klauzule złożone z jednego dłuższego wyrazu, który poza własnym akcentem wyrazowym „uzyskuje” także drugi, dodatkowy akcent (np. cursus planus: èxaudiétis) ${ }^{231}$. G. Lindholm stwierdziła, że takie niekanoniczne rozwiązania nie były spotykane często - przedstawienie ich było jednak konieczne, ponieważ wszystkie opisane wyżej przypadki znajdują odzwierciedlenie w Długoszowym Żywocie ${ }^{232}$.

Zbadałam cursus w najbardziej wzniosłych częściach utworu, przedstawiających jedną z mów Stanisława do Bolesława, męczeństwo św. Stanisława, zrośnięcie się jego ciała, wstąpienie do nieba i rozmowę z Chrystusem ${ }^{233}$. Analizę przeprowadziłam na tekście kodeksu z Archiwum Krakowskiej Kapituły Katedralnej, sygn. 214 (202 według numeracji I. Polkowskiego), za pośrednictwem mikrofilmu ${ }^{234}$. Pod uwagę wzięłam słowa poprzedzające znaki przestankowe występujące w tym rękopisie:

227 R.G. Witt, In the Footsteps, s. 509-514.

${ }_{228}$ M. Mejor, Rytmika prozy Brunona z Kwerfurtu (List do króla Henryka II), w: Bruno z Kwerfurtu: osoba, dzieło, epoka, red. M. Dygo, W. Fałkowski, Pułtusk 2010, s. 273-278; T. Jasiński, Gall Anonim - poeta i mistrz prozy. Studia nad rytmika prozy i poezji w okresie antycznym i średniowiecznym, Kraków 2016; L. Kotyński, Rytmika, s. 161-176 (zob. uwagę M. Plezi, Transmundus, s. 168 n. o pracy L. Kotyńskiego); M. Plezia, List biskupa Mateusza do św. Bernarda, w: Prace z dziejów Polski feudalnej ofiarowane Romanowi Grodeckiemu w 70. rocznice urodzin, red. Z. Budkowa i in., Warszawa 1960, s. 123-140.

229 M.H. Witkowska, ,Vita sanctae Kyngae ducissae Cracoviensis” jako źródło hagiograficzne, Rocz. Hum., 10, 1961, nr 2, s. 77; stwierdzono częste użycie cursus w hagiografii franciszkańskiej: B. Terracini, Il „,cursus” e la questione dello „, Speculum perfectionis”, „Studi Medievali”, 4, 1912-1913, s. 65-109.

${ }^{230}$ Wszystkie przykłady cursus zaczerpnięto z: T. Janson, Prose Rhythm, s. 10 n., 28 n., 31; M. Mejor, Florilegium. Studia o literaturze tacińskiej XIII-XVII wieku w Polsce, Warszawa 2015, s. 73.

231 T. Janson, Prose Rhythm, s. 11.

${ }^{232}$ G. Lindholm, Studien, cyt. za: T. Janson, Prose Rhythm, s. 12.

233 VSt, tr. I, s. 51-54 (rozdz. 8), 62-68 (rozdz. 10), 68-77 (rozdz. 11).

${ }^{234}$ BN, mkf 11343, s. 59-63, 72-91. W wyliczeniach uwzględniłam te miejsca, które - oglądane na mikrofilmie - nie budziły wątpliwości co do użycia znaków interpunkcyjnych. 
punctum (kropkę), virgula (skośną kreskę przypominającą przecinek) i periodus (połączenie punctum i virgula) oraz wyrazy poprzedzające słowa napisane wielką literą (gdy z treści wynikało, że słowo zapisane wielką literą rozpoczyna nową myśl). W wyodrębnionych 612 miejscach zaobserwowałam 447 klauzul reprezentujących cztery opisane wyżej typy cursus. Częstotliwość występowania poszczególnych rodzajów klauzul przedstawia poniższa tabela.

Tabela 8. Cursus w Żywocie św. Stanisława Jana Długosza (strony według rękopisu Archiwum Krakowskiej Kapituły Katedralnej, sygn. 214 (202), oraz wydania I. Polkowskiego i Ż. Pauliego)

\begin{tabular}{|c|c|c|}
\hline \multirow[t]{3}{*}{ cursus planus } & régni coeléstis (s. 60/52) & \multirow[t]{6}{*}{ w sumie 149 klauzu } \\
\hline & póssit, infixit (s. 79/67) & \\
\hline & aetérnae suscépta (s. 81/69) & \\
\hline \multirow{3}{*}{$\begin{array}{l}\sim \text { cursus planus (z niekanonicznym podziałem } \\
\text { wyrazów) }\end{array}$} & milítibus trádit (s. 78/66) & \\
\hline & praéceps in térram (s. 75/64) & \\
\hline & èxplicatúros (s. 87/74) & \\
\hline \multirow[t]{3}{*}{ cursus velox } & magnitúdinem aggravásse (s. 60/51) & \multirow[t]{6}{*}{ w sumie 65 klauzul } \\
\hline & suscéperat inimícum (s. 72/62) & \\
\hline & ómnibus venerándum (s. 86/73) & \\
\hline \multirow{3}{*}{$\begin{array}{l}\text { c cursus velox (z niekanonicznym podziałem } \\
\text { wyrazów) }\end{array}$} & sácri divelleréntur (s. 79/67) & \\
\hline & íri pertimescátis (s. 76/65) & \\
\hline & cónditor et redémptor (s. 74/63) & \\
\hline \multirow[t]{3}{*}{ cursus tardus } & pretiósa heréditas (s. 61/53) & \multirow[t]{6}{*}{ w sumie 85 klauzul } \\
\hline & mánus contínuit (s. 79/67) & \\
\hline & límen excésserat (s. 80/68) & \\
\hline \multirow{3}{*}{$\begin{array}{l}\text { cursus tardus (z niekanonicznym podziałem } \\
\text { wyrazów) }\end{array}$} & máxime póterat (s. 80/68) & \\
\hline & áusus, non régii (s. 60/52) & \\
\hline & vitam translátus est (s. 90/76) & \\
\hline \multirow[t]{3}{*}{ cursus trispondaicus } & concéssit principátum (s. 63/54) & \multirow[t]{6}{*}{ w sumie 148 klauzu } \\
\hline & trucidatiónem coarmábat (s. 72/62) & \\
\hline & pisce glutirétur (s. 80/68) & \\
\hline \multirow{3}{*}{$\begin{array}{l}\text { cursus trispondaicus (z niekanonicznym } \\
\text { podziałem wyrazów) }\end{array}$} & ánimum inténdit (s. 72/62) & \\
\hline & laetándi quam doléndi (s. 91/77) & \\
\hline & strátos se finxísse (s. 76/65) & \\
\hline
\end{tabular}

Powyższy zestaw danych wymaga ostrożnej interpretacji. Badając cursus, należy najpierw rozważyć, czy pisarz zastosował go świadomie - możliwe jest bowiem, że postawione obok siebie słowa układają się w klauzulę, choć nie było to celem autora. Sądzi się, że o zamyśle twórczym świadczy używanie określonych typów cursus częściej niż pozostałych, np. w Kronice Galla widać predylekcję do stosowania cursus velox, a w Kronice Kadłubka (jak się zdaje) - cursus tardus ${ }^{235}$; użycie „najrozmaitszych klauzul" stało się dla Aleksandra Gieysztora podstawą do stwierdzenia, że autor tzw. encykliki Sergiusza IV „mistrzem tej formy nie był, stosował ją raczej z przypadku, niż z głębszym namysłem i sztuką"236. Dotychczasowe badania pokazują też, że w tekstach rytmizowanych świadomie proporcje występowania cursus są inne niż w tekstach rytmizowanych bezwiednie: w tym drugim przypadku notuje się przewagę cursus trispondaicus i cursus planus nad występującymi zdecydowanie rzadziej cursus velox oraz cursus tardus ${ }^{237}$.

${ }^{235}$ Zob. odniesienia do literatury w przyp. 228

${ }^{236}$ A. Gieysztor, Ze studiów nad geneza wypraw krzyżowych. Encyklika Sergiusza IV (1009-1012), Warszawa 1948 , s. 31.

${ }^{237}$ M. Plezia, Transmundus, s. 168. 
W świetle tych informacji można wątpić, czy cursus obecny w Długoszowym Żywocie został zastosowany świadomie. W analizowanej próbie zaobserwowałam bowiem wszystkie typy klauzul, i to w różnych (tj. także niekanonicznych) wariantach, a proporcje, w których występują klauzule, przypominają rozkład cursus w tekście nierytmizowanym (wiodące cursus trispondaicus i planus, w mniejszym i podobnym do siebie natężeniu cursus velox i tardus). Oprócz tego w badanych fragmentach obok klauzul występuje niemało form nieregularnych, niewpisujących się w schematy czterech klasycznych typów cursus (165 form nieregularnych wobec 447 zauważonych klauzul) ${ }^{238}$.

Nawet jeśli Długosz nie wykorzystywał cursus jako środka artystycznego wyrazu, nie musi to negatywnie świadczyć o jego warsztacie pisarskim. Klauzule rytmiczne, jak wspomniałam, powszechnie stosowane były we wcześniejszych czasach, ale stosunek do nich w późnośredniowiecznej Polsce, jak mi się zdaje, nie został dotąd naświetlony. Nie można więc stwierdzić z pewnością, czy komponowanie tekstu wedle zasad cursus uznawano za obowiązek ówczesnego twórcy. $Z$ tego względu konieczne są dokładne badania nad rytmiką nie tylko prozy Długosza, ale też późnośredniowiecznych produktów kancelaryjnych i dzieł pisarzy tego okresu - dopiero wówczas można będzie stwierdzić, co o warsztacie pisarskim danego autora świadczy jego stosunek do klauzul rytmicznych.

\section{Żywot św. Stanistawa Jana Dlugosza i Żywot większy dominikanina Wincentego}

Przystępując do opracowania nowego żywotu św. Stanisława, Długosz miał do dyspozycji rozmaite źródła. Przede wszystkim były to XIII-wieczne Żywot mniejszy i Żywot większy dominikanina Wincentego oraz liryka liturgiczna tego samego twórcy. Dochodziły do tego Katalogi biskupów krakowskich, Kronika Wincentego Kadłubka wraz z Komentarzem Jana Dąbrówki, Kronika Galla Anonima, Kronika wielkopolska i Rocznik mansjonarzy krakowskich (tzw. Rocznik świętokrzyski nowy) ${ }^{239}$. Miał też dostęp do dokumentów związanych z kanonizacją biskupa. Z wszystkich tych źródeł dziejopis chętnie korzystał, wcielając do Żywotu co ciekawsze i bardziej efektowne wątki; nie informował przy tym o swoich źródłach, co było typowe dla praktyki hagiograficznej. Wprowadzał do historii też własne amplifikacje, które wynikały z prawdopodobieństwa albo podyktowane były troską o wewnętrzną logikę tekstu. Poza tradycją piśmienną, na wzór dominikanina Wincentego ( $V M i$ 1; VMa I 4), Długosz odwołał się do tradycji ustnej, opisując pobicie młodego Stanisława w Borownie, znieważenie biskupa przez szlachcica Jana z Brzeźnicy, porwanie Krystyny z Bużenina przez Bolesława Śmiałego czy śmierć króla ${ }^{240}$. Na nawiązanie do tradycji lokalnej wskazuje zawsze nazwa miejscowości bądź imię i pochodzenie osoby, z którą związane jest podanie, a także informacja, że zjawisko (nieurodzaj, choroba) nadal trwa lub nazwa miejsca zachowała się do czasów autora.

Spośród wyżej wymienionych źródeł w niniejszym artykule omawiam wyłącznie stosunek tytułowego żywotu do Żywotu większego dominikanina Wincentego ${ }^{241}$. Poniżej prezentuję wybrane zmiany

${ }^{238}$ Por. tamże, s. 167 n., gdzie na dokumencie sporządzonym zgodnie z zasadami cursus przez Transmundusa, autora podręcznika dotyczącego ars dictaminis, również występują formy nieregularne (ok. 30\% klauzul pobocznych wyróżnionych przez M. Plezię) - być może więc pojawianie się nieregularności obok klauzul nie musi przeczyć tezie o świadomym i celowym stosowaniu cursus przez pisarza.

${ }^{239}$ K. Krotoski, Ś. Stanisław biskup, s. 74-104; D. Turkowska, Etudes, s. 16-25; M. Plezia, Dookoła sprawy, s. 369-380.

240 VSt, s. 12 n., 21 n., 26 n.; K. Krotoski, Ś. Stanisław biskup, s. 85, zwrócił uwage, że choroby i deformacje cielesne rzekomych potomków Bolesława Śmiałego mogą wskazywać na „złośliwą gadkę szlachecką” jako na źródło podania; VSt, s. 89.

${ }^{241}$ Jako że w pracy Długosza nie ma takich przejątków z Żywotu mniejszego, które nie znajdowałyby się w Żywocie większym, a Żywot większy jest obszerniejszy i bogatszy w informacje od Żywotu mniejszego, w niniejszym artykule piszę jedynie o Żywocie większym, ze świadomością, że Długosz znał na pewno oba dzieła. Żywot mniejszy zapisywano bowiem głównie w pasjonałach, legendarzach i brewiarzach obok legend o innych świętych popularnych w Polsce (Pięciu Braciach Męczennikach, św. św. Cyrylu i Metodym, św. Florianie, św. Jadwidze, św. Wacławie, św. Wojciechu), czyli w księgach znanych wszystkim średniowiecznym duchownym; zob. Vita s. Stanislai episcopi Cracoviensis (Vita minor), wyd. W. Kętrzyński, w: MPH, t. 3, s. 239-244; badania nt. datacji Żywotu mniejszego i Żywotu większego podsumował W. Drelicharz, Idea zjednoczenia królestwa, s. 117-123. 
wprowadzone przez Długosza, które umożliwiają dokładniejsze scharakteryzowanie jego pisarskiego warsztatu. Pokazuję różnice w kompozycji obu utworów i tłumaczę ich przyczyny; przedstawiam też, jak historyk odniósł się do niektórych informacji zawartych w Żywocie większym. Poza obrębem niniejszych rozważań zostaje natomiast problem Długoszowych amplifikacji w stosunku do treści Żywotu większego.

\section{Kompozycja}

Powstały w XIII w. Żywot większy był dla Długosza pierwowzorem i punktem odniesienia podczas pisania Żywotu krakowskiego biskupa. Wielu badaczy zwracało już uwagę na duże podobieństwo obu dzieł. Siłą rzeczy XIII-wieczny żywot był jedynym utworem, z którego dziejopis mógł zapożyczyć kompozycyjny schemat dla swojej pracy - Długosz przejął go niemal w całości, wprowadzając zmiany właściwie tylko w zakresie ekskursów historycznych i historiozoficznych.

W przeciwieństwie do Żywotu większego, w Żywocie Długosza brak dygresji o Mieszku I (VMa II 27), Bolesławie Chrobrym ( $V M a$ I 1; II 26), zjeździe gnieźnieńskim ( $V M a$ I 2), Mieszku II ( $V M a$ I 3 ) oraz Kazimierzu Odnowicielu i Cluny ( $V M a$ II 9-13), które ukazałyby życie świętego na tle dziejów Polski. Najwyraźniej dziejopis uznał, że w przypadku tak popularnej postaci jak św. Stanisław (co potwierdza ówczesny ruch pątniczy ${ }^{242}$ ) było to zbyteczne. Chcąc mimo wszystko usytuować opisywane wydarzenia w czasie, Długosz podał informacje o latach narodzin świętego, jego ordynacji, męczeństwa i kanonizacji. Poszedł w tej kwestii za tradycją hagiograficzną, wedle której żywot miał służyć tylko przedstawieniu życia (a właściwie świętości) opisywanej postaci, nie zaś historycznego kontekstu. Innym względem, który nakazał kanonikowi eliminację wyżej wymienionych dygresji historycznych, była kompozycyjna i narracyjna spójność pracy. W Żywocie większym passusy historyczne są obszerne i wprowadzone znienacka, przez co rozbijają tok opowiadania i utrudniają zbudowanie napięcia ${ }^{243}$. Tymczasem w XV-wiecznym Żywocie, gdzie dominantą dzieła jest stopniowa eskalacja konfliktu króla i biskupa, kompozycja pełni kluczową funkcję i to do niej dostosowany jest dobór oraz układ opisywanych zdarzeń - nawiązania do początków Polski były od tych zdarzeń zbyt daleko.

Za to podobnie do dominikanina Wincentego ( $V M a$ II 25-27) za godne szerszego opisania Długosz uznał dzieje Polski po zabójstwie św. Stanisława. Zrobił tak z trzech względów: (1) w innych źródłach znalazł informację o interdykcie nałożonym na Polskę oraz losach króla i zapragnął umieścić je w swoim dziele ${ }^{244}$; (2) uważał za konieczne wytłumaczyć, czemu kanonizacji męczennika, którego świętość miała być tak oczywista, dokonano dopiero 174 lata po jego śmierci; wreszcie (3) nakreślenie dziejów Polski po 1079 r. pozwoliło mu na historiozoficzny wywód, w którym zaprezentował własne poglądy na przyczynę rozbicia dzielnicowego, utratę korony i panowanie obcej dynastii. Te wiadomości umieścił w końcowej części tractatus I i prologu tractatus II, przed spisem cudów, analogicznie do Żywotu większego. Opowiadanie Długosza zawiera jednak znacznie więcej szczegółów, łącznie z psychologiczną motywacją działań Bolesława Śmiałego, polskich biskupów i Władysława Hermana. Historyk przedstawił także dalsze losy wszystkich, których dotyczyła śmierć Stanisława: króla, jego rodziny, dostojników, współwinnych żołnierzy, wakującego biskupstwa krakowskiego oraz interdyktu nałożonego na sprawców zbrodni i całe królestwo ${ }^{245}$.

242 Świadczą o nim XV-wieczne (lata 30.-70.) ogłoszenia doznanych cudów dokonane na Wawelu i na Skałce, które to miracula Długosz przywołał w omawianym Żywocie: VSt, s. 151-171, 177-181; zob. też J. Długosz, Liber beneficiorum, t. 2, s. 263 (Pustynia), 269 (Szczepanów). Pokanonizacyjny kult św. Stanisława na podstawie wyżej wymienionych źródeł scharakteryzowała A. Witkowska, Kulty patnicze, s. 82-87.

${ }^{243}$ Por. M. Plezia, Wincenty z Kielc, historyk polski z pierwszej połowy XIII wieku, St. Źródł., 7, 1962, s. 25 n.; tenże, Dookoła sprawy, s. 361; Średniowieczne żywoty i cuda, s. 104. Jak się wydaje, nie był to ze strony dominikanina Wincentego celowy zabieg retardacyjny.

${ }^{244}$ Katalogi biskupów krakowskich, s. 44 (IV red.); Rocznik świętokrzyski, wyd. A. Rutkowska-Płachcińska, w: MPH s.n., t. 12, Kraków 1996, zap. 20, s. 19; Jan z Dąbrówki, Komentarz do „Kroniki polskiej” mistrza Wincentego zwanego Kadlubkiem, wyd., wstęp i przyp. M. Zwiercan, współpr. A.Z. Kozłowska, M. Rzepiela, Kraków 2008, s. 96 n. (epist. 22).

${ }^{245}$ Por. IV red. Katalogu biskupów krakowskich, zap. 9, i Rocznik mansjonarzy krakowskich, zap. 20-21. Wiadomość z Katalogu wskazał K. Krotoski, Ś. Stanisław biskup, s. 96, a z Rocznika - M. Plezia, Dookoła sprawy, s. 371. 
Dziejopis odszedł przy tym od linearnego opisu zdarzeń. Najpierw przedstawił to, co nastąpiło po śmierci biskupa: usprawiedliwianie się króla i jego dostojników, oczernianie męczennika, reakcja Kościoła krakowskiego i papieża, cuda nad ciałem zmarłego. Dopiero później przeszedł do wewnętrznej przemiany Bolesława, która dokonywała się po zbrodni z biegiem czasu: z początku duma i lekceważenie reakcji otoczenia, potem zwątpienie i strach przed opinią publiczną, w końcu żal i przerażenie. Po dwutorowym przedstawieniu sytuacji w kraju i w sercu Bolesława kanonik podał ostateczną ocenę charakteru i czynów króla - w Żywocie większym nie ma takiego końcowego podsumowania, a bilans dobrych i złych cech władcy, z przewagą tych drugich, umieszczono jeszcze przed opisem zabójstwa św. Stanisława (VMa II 15).

Oprócz powtórzenia lub modyfikacji elementów ogólnego schematu kompozycyjnego Długosz zmienił rozmieszczenie szczegółowych informacji znanych z dzieła dominikanina, aby inaczej rozłożyć napięcie i trzymać się chronologicznego porządku zdarzeń (ordo naturalis).

Informację o metropolitalnej godności Krakowa (VMa II 14), oderwaną w Żywocie większym od fragmentu o święceniach kapłańskich i ordynacji św. Stanisława (VMa I 8), Długosz umieścił w Żywocie w postaci wzmianki przy okazji charakterystyki Lamberta Suły. Dokonując przeniesienia tego fragmentu, wpisał go w ciąg wydarzeń, który u dominikanina Wincentego był zaburzony. Jak wspomniałam wyżej, nie nadał tej historii tak ponurego kolorytu jak w innych dziełach, bo nie współgrałoby to z wizerunkiem tego biskupa, którego zasługą było pozyskanie Stanisława dla Kościoła krakowskiego.

W taki sam sposób kanonik postąpił z informacją z Żywotu większego o tym, jak św. Stanisław unikał kontaktu z królem ( $V M a$ I 10). Długosz umieścił ją w Żywocie znacznie później niż dominikanin Wincenty: nie we wzmiance o winach Bolesława, lecz we fragmencie bezpośrednio poprzedzającym opis śmierci biskupa - tam taka informacja lepiej buduje napięcie.

\section{Wykorzystanie i uzupełnianie informacji}

Odrębną kwestią jest to, jak Długosz zużytkował wiadomości obecne w Żywocie większym. Zwrócono już uwagę na to, że omawiane dzieło jest cztero- czy pięciokrotnie dłuższe od pracy XIII-wiecznej ${ }^{246} \mathrm{i}$ że ,zz krótkiej zapiski źródłowej wysnuwa on [Długosz - H.R.] opowiadanie na pół albo i całą stronę"247. Niemniej warto podkreślić, że te historie nie zostały rozbudowane w sposób przypadkowy. Wiele wzmianek źródłowych napotkanych w Żywocie większym (nawet takie składające się z jednego słowa!) Długosz rozwinął w oddzielne wydarzenie albo obraz, tworząc kolejne exempla cnoty świętego. To rozwiązanie umożliwia wywarcie większego wpływu na odbiorcę i zapadnięcie przekazu (scenki czy obrazu właśnie) w jego pamięć. Już jakiś czas temu zauważono skłonność Długosza do sytuacyjnej charakterystyki swoich bohaterów ${ }^{248}$. Poniższa tabela zawiera zestawienie opisów młodego św. Stanisława z Żywotu większego i Żywotu Długosza. Zebrane dane ukazują, jak ilościowe zmiany, które Długosz wprowadził do pracy, służą uzupełnieniu obrazu znanego z XIII-wiecznego żywotu i przedstawieniu pełniejszego portretu krakowskiego biskupa.

Tabela 9. Opis cnót św. Stanisława jako dziecka i młodzieńca w Żywocie większym dominikanina Wincentego i Żywocie św. Stanisława Jana Długosza

\begin{tabular}{|c|c|}
\hline$V M a$ I 6 & $V S t$ \\
\hline "fuit etenim eleganter natus" & $\begin{array}{l}\text { „parentes, pro conditione carnis et saeculi, nobiles illi fuere atque praestantissimi, atque } \\
\text { tali filio digni. Pater eius [...] non tam nobilitate pollens generis, quam virtutum splendore: } \\
\text { vir ex militari ordine et equestri, et qui inter omnes domus et familiae suae contribules, } \\
\text { primarius et praecipuus habebatur, sed et inter alios Polonorum proceres, morum et } \\
\text { virtutum iubare, militarisque rei gloria eminebat. Mater eius [...], femina et ipsa genere }\end{array}$ \\
\hline
\end{tabular}

${ }^{246}$ K. Krotoski, Ś. Stanisław biskup, s. 81.

247 M. Plezia, Dookoła sprawy, s. 373.

${ }^{248}$ M. Koczerska, Mentalność Jana Dlugosza, s. 118. 


\begin{tabular}{|c|c|}
\hline & $\begin{array}{l}\text { ingenua, sed pudicitiae magis decore nobilior, de raris religiosa femina, clara et celebris } \\
\text { inter feminas suae regionis suique temporis habebatur" (s. 9) }\end{array}$ \\
\hline $\begin{array}{l}\text { „in cultu Christiane religionis } \\
\text { educatus" }\end{array}$ & $\begin{array}{l}\text { "uno animo eodemque devotionis et caritatis tenore et in Deum et in proximum usi, } \\
\text { fecunditatem sibi praestari votis plurimis deposcebant, prolem nascituram obsequio et } \\
\text { sorti Dei mancipaturi" (s. 10) }\end{array}$ \\
\hline „Deo devotus” & $\begin{array}{l}\text { „teneriori [...] infantia perfunctus, saepe compertus est molle stratum, in quod parentum } \\
\text { indulgentia collocabatur, deseruisse et in nuda humo aut palearum stramento quietis } \\
\text { residuum exegisse” (s. 11) }\end{array}$ \\
\hline „mente pudicus, corpore castus” & $\begin{array}{l}\text { „carnem quoque, ne lascivire inciperet, et calentis aetatis flammas ieiuniorum frigore et } \\
\text { carnis maceratione curavit restinguere, custodiens illam ab omni illecebra, et ab omni } \\
\text { feminarum contubernio et contagione; perpetuam eligens et custodiens castitatem” (s. 14) }\end{array}$ \\
\hline „habitu reverendus” & „ac multos propterea graves viros ad sui amorem et admirationem perliceret” (s. 12) \\
\hline „locuplex rebus” & $\begin{array}{l}\text { "amplum utriqe dominii patrimonium, ferax census et plusquam mediocris substantia, } \\
\text { generi respondens et conditioni” (s. 9) }\end{array}$ \\
\hline „moribus maturus” & $\begin{array}{l}\text { "tantum insuper in gestibus moribusque et singulis actionibus pudorem, tantam in sermone } \\
\text { et vultu modestiam servasse spectatus est et inclinationem ad virtutem, ut nec iocasse } \\
\text { nec risisse effusius notaretur" (s. 12) }\end{array}$ \\
\hline „,ingenio acutus” & $\begin{array}{l}\text {,in quibus addiscendis docile apparuit illum ingenium sortitum esse, cupidum quoque } \\
\text { litterarum et praeproperum, et quod spem non mediocrem eruditoribus ingerebat; memo- } \\
\text { riam tenacem, quae illos ad puerum operosius imbuendum pertrahebat” (s. 12) }\end{array}$ \\
\hline „sermone discretus” & „mirifica in verbis suavitas, in factis vero comitate condita gravitas conspiciebatur” (s. 13) \\
\hline „consilio providus” & $\begin{array}{l}\text { "quaecumque negotia per se provida deliberatione discuteret, et mirandum se cunctis non } \\
\text { ex factis tantum sed ex verbis praeberet, consiliis erudiens atque curans audientes" (s. 16) }\end{array}$ \\
\hline $\begin{array}{l}\text { „in iudicio iustus et ad omne bonum } \\
\text { habilis et promptus” }\end{array}$ & $\begin{array}{l}\text { „fiebat ad illum ex universo Poloniae regno frequens tam ecclesiasticorum quam secula- } \\
\text { rium concursus, vel erudiri in casibus ambiguis expetentium, vel suis conscientiis consuli } \\
\text { deposcentium; quos ille, ut erat natura facilis et lenis, benigne exceptos sua institutione } \\
\text { et doctrina reficiebat" (s. } 15 \text { n.) }\end{array}$ \\
\hline
\end{tabular}

Autor Żywotu twórczo ustosunkował się do wiadomości, jakie dominikanin Wincenty przedstawił na temat życia krakowskiego biskupa - wprowadził do nich mianowicie zmiany jakościowe. Uściślił na przykład informacje o edukacji św. Stanisława. Wincenty na ten temat napisał tylko ( $V M a$ I 6): ,parentes illius videntes puerum racione preditum, animo studiosum, decreverunt eum scolasticis disciplinis subiciendum"249. Wykorzystał w tym fragmencie, jak się zdaje, topikę hagiograficzną. Długosz znacznie uściślił informacje o wykształceniu przyszłego biskupa: opisawszy początkową formację w sztukach wyzwolonych (artes liberales), odebraną od bliżej nieokreślonych nauczycieli (eruditores), wskazał na gnieźnieńską szkołę katedralną jako miejsce, w którym Stanisław pobierał „wyższe nauki” (altior doctrina). Wybór przez Długosza akurat tej szkoły podyktowany był dwoma względami. Po pierwsze, jak autor sam napisał, była to wówczas, w drugiej połowie XV w., najlepsza szkoła w kraju (znaczenie krakowskiej szkoły katedralnej spadło bowiem przez bliskość uniwersytetu). Po drugie, umieszczenie bohatera akurat w tej szkole zdaje się ukłonem w stronę adresata Żywotu, Sędziwoja z Czechla, który związany był z gnieźnieńską kapitułą katedralną i przez niemal dekadę wykładał teologię w tamtejszej szkole katedralnej.

Także narracja o dalszej formacji św. Stanisława bazuje na Żywocie większym (VMa I 7), którego autor stwierdził:

puerilibus tandem rudimentis sufficienter instructus, cum iam esset iuvenis adultus, fertur ad locum, ubi tunc forte generale studium florebat, convolasse et in facultate liberalium arcium tempus non modicum exegisse. In iure quoque canonico ac divino comprobatur studuisse, quia [...] vir litteratus et in divinis rebus illuminatus perhibetur fuisse $\mathrm{e}^{250}$.

$249 V M a$, s. 368.

${ }^{250} V M a$, s. 369 
Dla Długosza oczywistym było, że wzmiankowanym ośrodkiem akademickim był Uniwersytet Paryski - w późnym średniowieczu wciąż sławne studium generale, w którym uczył się i wykładał Sędziwój z Czechla. Dziejopis uściślił typ nauk pobieranych na uniwersytecie (teologia) i czas, przez jaki Stanisław je studiował (siedem lat - to pozwalało odbyć znaczną część studiów teologicznych, ale nie całość, co pozostaje w zgodzie z tezą Długosza, że Stanisław nie uzyskał doktoratu z teologii, choć miał taką możliwość i zachęcano go do tego). Uważa się, że opis zagranicznych studiów Stanisława mógł powstać na podstawie wspomnień Sędziwoja ${ }^{251}$. Oprócz tego sam fakt związania przyszłego świętego ze szkołą i uniwersytetem adresata utworu służył pochwale Sędziwoja i był sposobem pozyskania jego życzliwości w ocenie dzieła.

Kolejnej zmiany w stosunku do Żywotu większego Długosz dokonał w opisie sprawy piotrawińskiej. Według dominikanina Wincentego (VMa II 1) na odzyskaniu Piotrawina zależało bliskim zmarłego rycerza Piotra. To oni mieli ukartować intrygę z postawieniem biskupa przed sąd władcy, wykorzystując gniew Bolesława dla swoich celów:

fratres eius vel amici propinquiores, tamquam defuncti legitimi successores ceperunt episcopum impetere de restituenda sibi hereditate. Iam quidem rex Boleslaus impaciens correccionis factus, contra episcopum sinistram voluntatem gerebat, sed nondum manifeste virus cordis eius efferbuerat. At cognati defuncti exspectato biennio vel amplius, quousque ira regis in episcopum excandesceret fervidius, episcopo de suo iure nolente cedere, rege instigante, compulsi sunt episcopum ad presenciam regis citare ${ }^{252}$.

Tymczasem u Długosza inspiratorem był król Bolesław, który zaczął prześladować biskupa Stanisława i postanowił wykorzystać sprawę piotrawińską do starcia z hierarchą ${ }^{253}$. Dziejopis ograniczył rolę krewnych Piotra i uczynił króla spiritus movens sporu o Piotrawin. Uwypuklił zamiary Bolesława, kontrastując je także z prawdziwym statusem sprawy - wszystko po to, aby podkreślić niegodziwość i wyrachowanie monarchy. Poza tym kanonik rozbudował Wincentyński passus o tym, jak świadkowie biskupa - zmuszeni przez króla - nie stawili się na sprawie i nie zeznawali na korzyść Stanisława ${ }^{254}$. Długosz znacznie poszerzył narrację XIII-wieczną, pogłębiając (oczywiście negatywną) charakterystykę króla Bolesława ${ }^{255}$. Ponadto dziejopis sprecyzował, że Piotr spoczął przy kościele parafialnym pw. św. Tomasza apostoła, który istniał w XV w. i odnotowany został w Księdze uposażeń. Rozwinął $\mathrm{w}$ ten sposób wiadomość Wincentego o pochówku in territorio eiusdem ecclesie (VMa II 1$)^{256}$.

Kanonik zmienił opowiadanie swojego pierwowzoru również w zakresie napomnień biskupa wobec króla. Wedle dominikanina Wincentego (VMa I 9) św. Stanisław „gorliwie nawoływał” (sedule commonebat) władcę do poprawy ${ }^{257}$, „wzywał” (provocabat) go do zmiany postępowania, „płakał” (deflebat) z powodu grzechów władcy. Biskup widział jednak, że król nie zareagował na jego napomnienie ${ }^{258}$ (VMa I 10). Wincenty użył w tym fragmencie czasu przeszłego niedokonanego (ind. impf. act.), aby podkreślić ciągłość opisywanych zdarzeń i ich iteratywny aspekt. Z kolei Długosz rozwinął wzmianki w pięć bezpośrednich zwrotów św. Stanisława do Bolesława ${ }^{259}$, składających się na ich trzy rozmowy,

251 Red[akcja], Jan Dlugosz o wielkopolskiej przygodzie, s. 142.

252 VMa, s. 374.

253 VSt, s. 33: „nepotes eius germanos Petrum, Iacobum et Sulislaum [...] ad impetendum Stanislaum Episcopum pro villa Pyotrawin, spondens illis facilem victoriam, perlicit Rex et coarmat, rem vulgatam et notissimam in contentionem adduci praecipiens".

${ }^{254} V M a$, s. 375: ,at illi mandato ac timore constricti tyranni nec in termino comparere presenti nec testimonium ferre ausi sunt veritati",

255 VSt, s. 33: „offerens se singulos testes, ex quibus Stanislai Episcopi pendebat victoria, a ferendi testimonii officio deterriturum, et omni ope atque suffragio pro deiiciendo Stanislao Episcopo ex villa Pyotrawin, et in eorum traducenda proprietatem, adnisurum".

256 VMa, s. 374; VSt, s. 33; J. Długosz, Liber beneficiorum, t. 2, s. 511; K. Krotoski, Ś. Stanisław biskup, s. 86.

$257 \dot{Z}$ ywot większy, s. 257; VMa, s. 370: „regem Boleslaum [...], cuius vita enormis erat, ut se corrigeret, sedule commonebat”.

${ }^{258} V M a$, s. 370: „,ernens [...] pontifex Stanislaus suam ammonicionem in ipso minime proficere”.

259 Wypowiedzi biskupa skierowane do króla: VSt, s. 25 (rozwiązłość), 29-32 (porwanie Krystyny z Bużenina), 44 (okrucieństwo wobec kobiet i niemowląt), 51-54 (groźba upadku królestwa), 55 (groźba klątwy). 
odpowiadające trzem ewangelicznym upomnieniom (Mt 18,15-17). Dzięki temu dziejopis rozbudował argumentacyjną warstwę Żywotu oraz zaprezentował kunszt literacki i oratorski. U Długosza Stanisław płakał nad królem jak Samuel za Saulem ${ }^{260}$ (jak w Żywocie większym, VMa I 9), a także umartwiał ciało postami i noszeniem włosiennicy oraz modlił się przed wizerunkiem Chrystusa i odprawiał msze ${ }^{261}$. Tak sugestywny opis narzuca odbiorcom wizualizację opisywanej sceny, przez co czyni przekaz dobitniejszym i bardziej poruszającym.

\section{Wnioski}

Niniejsze badanie pozwala na wstępną (konieczne są bowiem jeszcze analogiczne studia nad $\dot{Z} y w o-$ tem bt. Kingi) ocenę warsztatu pisarskiego Długosza-hagiografa. Aby właściwie zinterpretować wyniki analizy, trzeba podkreślić, że w średniowieczu od twórcy oczekiwano dostosowania się do konwencji danego gatunku literackiego. Zastosowanie w utworze licznych „wędrujących motywów” stanowiło świadectwo sprawności pisarskiej i było oceniane in plus. Nie oczekiwano od twórcy wykazania się własną pomysłowością, ale inwencja i modyfikacja toposów była dopuszczalna i doceniana. Swoboda artystyczna nie mogła być jednak nieograniczona - silne było przeświadczenie o konieczności wpisania się $\mathrm{w}$ jakąś tradycję̨262

W tym świetle pisarski warsztat Długosza można, jak sądzę, ocenić bardzo wysoko. Konstrukcja Żywotu odpowiada konwencji zarówno od strony zewnętrznej (trójdzielność dzieła), jak i wewnętrznej (prologus, narratio, argumentatio, epilogus). W obrębie tych części kanonik wykorzystał wiele tradycyjnych elementów. W części narracyjnej zastosował szereg utartych toposów, których nie było w jego pierwowzorze. Barwność i szczegółowość opowiadania, w połączeniu z umiejscowieniem akcji w realiach XV w., miała sprawić, żeby przebieg życia świętego zapadł w pamięć odbiorcy. W licznych fragmentach o charakterze argumentacyjnym wykorzystano wszystkie możliwe sposoby dowiedzenia świętości krakowskiego biskupa. Dla dodatkowego poruszenia odbiorcy dziejopis wykorzystał cztery znane metody amplifikacji retorycznej. Całość żywotu wypada bardzo bogato, różnorodnie, ale spójnie. Autor świadomie gra mową zależną i niezależną, wykorzystując ją do celów perswazyjnych. Opowiadanie prowadzone jest wartko, tempo przyśpiesza w miarę rozwoju akcji (czyli wraz z eskalacją konfliktu króla i biskupa). Funkcję retardacyjną pełnią obszerne opisy dawnych realiów, przy czym zostały one umieszczone głównie w początkowej części dzieła; nie ma ich w dalszych partiach, gdzie Długosz skupił się na budowaniu napięcia. Wykorzystanie przez Długosza teorii trzech stylów stanowi dowód jego dużej świadomości teoretycznoliterackiej. Styl należało bowiem zastosować do odpowiedniego typu sprawy, a w obrębie każdego z nich twórca mógł umieścić tylko określone środki wyrazu. Długoszową realizację tria genera dicendi pozytywnie ocenił już Sędziwój z Czechla, a opinia współczesnego autorowi erudyty jest dość dobrym (choć jednak stronniczym) probierzem kunsztu Żywotu.

Zwrócono również uwagę na stosunek XV-wiecznego Żywotu do jego o 200 lat starszego pierwowzoru. Długosz w pracy zachował wiele elementów wspólnych z Żywotem większym, czasem dokonywał jednak modyfikacji. Jego zmiany kompozycyjne wynikają z dostosowania treści legendy do współczesnych sobie czasów i z dbałości o zrównoważony wzrost napięcia dramatycznego w Żywocie. Tym drugim względem podyktowane zostały też drobne przemieszczenia informacji zaczerpniętych od dominikanina Wincentego, które, niezmienione, w innych miejscach lepiej współgrały z zasadniczą akcją utworu. Długosz z dużą swobodą odniósł się też do wiadomości, które znalazł w Żywocie większym. Wzbogacił je o nowe szczegóły i stworzył z nich całe sceny lub obrazy, ponieważ każdy nowy szczegół czynił Żywot bogatszym, a zatem atrakcyjniejszym utworem literackim.

Nie twierdzę, że pisząc $\dot{Z} y w o t$, Długosz w pełni świadomie wykorzystywał środki artystycznego wyrazu. Myślę jednak, że odebranie typowej dla tej epoki formacji wyrobiło w nim określony

260 VSt, s. 57: „non secus quam Samuel quondam pro Saule interpellabat”.

261 VSt, s. 57 n.: „frequentius sanctissimi sacrificii adolevit incensum”; „frequentiusque ad imaginem Crucifixi conversus”.

${ }^{262}$ P. Bering, Struktury narracyjne, s. 190-192. 
gust literacki oraz pewne predylekcje i nawyki pisarskie. W późniejszych latach pogłębiły się one przez dorosłe lektury kanonika i jego własną praktykę pisarską. Pod wpływem tych wszystkich czynników Długosz napisał żywot tak bardzo odpowiadający konwencji hagiograficznej oraz estetyce swoich czasów (o tym, że praca istotnie trafiła w gusta epoki, świadczy chociażby jej wczesny pierwodruk: $1511 \mathrm{r}$.).

Długosz spędził na Uniwersytecie Krakowskim prawie trzy lata (1428-1431), ale podobnie jak większość studentów tego studium generale nie zdobył żadnego tytułu. Znajomość rudymentów sztuki dyktatu mógł zdobyć w ramach obowiązkowych wykładów uniwersyteckich (libri ordinarii) przez lekturę Doctrinale puerorum Aleksandra de Villa Dei (XII-XIII w.), Poetria nova Gotfryda de Vino Salvo (XII-XIII w.) czy gramatyki Donata (IV w.). Mógł pogłębić tę wiedzę, uczęszczając na wykłady odbywające się w katedrze fundacji Tomasza Nowki z Lelowa (na której w latach 1427-1433 wykładał Jan Dąbrówka) oraz katedrze fundacji Katarzyny Mężykowej, żony Jana Mężyka z Dąbrowy, gdzie uczono sztuki komponowania listów i dokumentów, a także wykładano podstawy poetyki i retoryki ${ }^{263}$. Brak potwierdzenia, że Długosz uczęszczał na te zajęcia, ale miał taką możliwość. Za to pewnym jest, że musiał opanować zasady dyktamenu w związku z pracą w kancelarii biskupa krakowskiego Zbigniewa Oleśnickiego ${ }^{264}$. Obecnie znanych jest osiem instrumentów notarialnych zredagowanych przez Długosza $^{265}$. Zasadnym jest zbadanie ich stylistyki oraz zwrócenie uwagi na literacki aspekt ogółu produkcji kancelarii Oleśnickiego (dokumenty, formularze) - pomogłoby to w pogłębieniu wiedzy na temat tamtejszej praktyki pisarskiej i formacji pracowników kancelarii biskupów krakowskich ${ }^{266}$.

Przeprowadzone badanie ukazuje żywotopisarską twórczość Długosza w pełniejszym świetle. Filologiczna analiza literackich walorów jego pisarstwa pozwala na zweryfikowanie dawniejszych poglądów o artystycznych predyspozycjach kanonika. Dotychczas twierdzono bowiem, że był on „osobowością raczej przeciętnej miary” $267 \mathrm{i}$,nie był wybitnym intelektualistą swojej epoki”268, a ,jego pisma zawdzięczają swe zalety sumienności i pracowitości autora, nie jego szerokim horyzontom ani przenikliwości, ani wybitnym zdolnościom artystycznym" ${ }^{269}$. Na podstawie przedstawionej analizy nie mogę w pełni zgodzić się z tymi twierdzeniami. Podobnie jak Michał Rzepiela, uważam, że są to oceny wydane nazbyt szybko $^{270}$.

Zwrócenie uwagi na niebadane dotąd elementy warsztatu Długosza (topika, retoryka, periody, cursus) może zachęcić do pogłębionych badań nad jego spuścizną i piśmiennictwem późnego średniowiecza. Za to prezentacja sposobu, w jaki dziejopis wykorzystał Żywot większy, uprawnia do rehabilitacji jego pracy, którą w przeszłości krytykowano za fikcyjne additamenta. Oba żywoty, XIII- i XV-wieczny, przy wstępnym oglądzie zdają się dość podobne. Analiza wprowadzonych przez kanonika modyfikacji, połączona z ich wyjaśnieniem, dowodnie świadczy jednak o twórczym stosunku Długosza do hagiograficznej tradycji o św. Stanisławie i wysokim poziomie jego pisarskiego warsztatu.

263 Wydania dokumentów fundacyjnych tych katedr: Codex Diplomaticus Universitatis Studii Generalis Cracoviensis, t. 1, Cracoviae 1870, nr 38; S. Kuraś, Fundacja kolegiatury epistolografii i sztuki pisania dokumentów w Akademii Krakowskiej w r. 1420, „Małopolskie Studia Historyczne”, 6, 1964, z. 3-4, s. 119-123; Zbiór dokumentów katedry i diecezji krakowskiej, cz. 2: 1416-1450, wyd. S. Kuraś, Lublin 1973, nr 233.

${ }^{264}$ M. Koczerska, Dlugosz jako sekretarz Zbigniewa Oleśnickiego, w: Jan Dlugosz. W pięćsetna rocznicę śmierci. Materiaty z sesji (Sandomierz 24-25 maja 1980 r.), red. F. Kiryk, Olsztyn 1983, s. 53-64; T. Michałowska, Średniowieczna teoria literatury w Polsce (ars dictaminis - jej pogranicza i funkcje), w: Literatura, historia, dziedzictwo. Prace ofiarowane profesor Teresie Kostkiewiczowej, red. T. Chachulski, A. Grześkowiak-Krwawicz, Warszawa 2006, s. 33.

265 Dyplomy te wymienia M. Koczerska, Zbigniew Oleśnicki i Kościół krakowski w czasach jego pontyfikatu 1423-1455, Warszawa 2004, s. 49, przyp. 69, 70

${ }^{266}$ M. Markowski, Tendencje rozwojowe piętnastowiecznej retoryki krakowskiej, w: Retoryka w XV stuleciu. Studia nad tradycjami, teoria i praktyka retoryki piętnastowiecznej, red. M. Frankowska-Terlecka, Wrocław 1988, s. 113, wspomniał, że „korespondencja, która wychodziła z jego [Zbigniewa Oleśnickiego - H.R.] kancelarii, była oparta nie tylko na zasadach średniowiecznej sztuki dyktatu, lecz także na naśladowaniu wzorów humanistycznych".

${ }^{267}$ U. Borkowska, Treści ideowe, s. 199.

268 Tamże.

269 M. Plezia, Jan Dlugosz, s. 170.

${ }^{270}$ M. Rzepiela, Rola frazeologii w narracji „Kroniki” Jana Dlugosza, w: Jan Dlugosz (1415-1480). Życie i dzieła, s. 246. 
Na koniec warto zadać pytanie, czy pisząc Żywot, Długosz posłużył się jakąś określoną „metodą hagiograficzną”, odrębną od zdiagnozowanej już jego „metody historycznej”, czy też różne swoje dzieła, reprezentujące wszak rozmaite gatunki literackie, opracowywał na podobnych zasadach. Z górą sto lat temu K. Krotoski trafnie podsumował, na czym polegają amplifikacje dziejopisa: „gdy w żadnem źródle nie znalazł Długosz faktu, który, zdaniem jego, wydarzyć się musiał, wytwarza go w swej wyobraźni”, oprócz tego wykorzystuje „niefortunne kombinacye”, „fikcyjne wyjaśnienia” i „z gołosłownej wzmianki źródła tworzy barwny obraz”. Ponadto „wytwarza domysły, często prawdopodobne, częściej jednak zupełnie nieuzasadnione"271.

Takie postępowanie nie wynikało jednak z niefrasobliwości czy nierzetelności, tylko była to świadomie obrana metoda badawcza i pisarska. Użycie jej wydaje się szczególnie uzasadnione w Żywocie, który - jako dzieło hagiograficzne - za cel ma przede wszystkim wykreowanie świętości i przekonanie odbiorców do jej podziwiania i naśladowania, nie zaś odtworzenie rzeczywistości. Niemniej Długosz (a także Sędziwój) był przekonany, że w Żywocie przedstawiona jest sama prawda. Identyczną metodę - de facto „metodę koniektury” (czyli domysłu na zasadzie prawdopodobieństwa i zgody z posiadaną wiedzą) - kanonik zastosował w pracy nad innymi dziełami, z Rocznikami na czele. Napisał m.in.: „nichil enim vetat credi posse, quod tantum possibile sit, sive sic sive aliter accidere potuisse"272.

Nie można zatem mówić o oddzielnej „metodzie hagiograficznej” i „metodzie historycznej” Długosza - dziejopis w obu przypadkach postępował tak samo. Tezę tę poprzeć można kilkoma argumentami zaczerpniętymi z Żywotu. Po pierwsze, wbrew tradycji hagiograficznej kanonik umieścił w nim aż siedem określeń czasu, nawiązując do typowo rocznikarskiej poetyki. Po drugie, również nietypowo, włączył do dzieła cztery pisma in extenso, ujawniając sentyment do pracy z dokumentem. Po trzecie, nie wahał się umieścić w żywocie treści historycznych i politycznych. Wcześniej aluzje historiozoficzne robił już w obu żywotach dominikanin Wincenty, ale dziejopis, poza wykładem swojej koncepcji historii narodowej, umotywował ją stricte historycznymi argumentami ${ }^{273}$. Z jednej więc strony Długosz dostosowywał się do istniejącej konwencji żywotopisarskiej, z drugiej zaś zachował samodzielność w jej obrębie, nadając Żywotowi św. Stanistawa unikalny, „historyczny” i „kancelaryjny” charakter.

\section{Jan Długosz's literary skills. The case of Life of St. Stanislaus}

Summary: The purpose of the study is to describe Jan Dlugosz (1415-1480) as a writer and hagiographer on the basis of his Life of St. Stanislaus (1460s, BHL 7839). In the first part of the article author presents a rhetorical division of the analysed source: (1) literary topoi contained in the prologue, (2) hagiographic topoi (with comparative examples derived from lives written by Jerome, Sulpicius Severus, and the Golden Legend), (3) argumentative parts throughout the whole Life (genus inartificiale probationum; genus artificiale probationum: loci a persona, loci a re, exempla, signa; congeries, incrementum, comparatio, ratiocinatio), as well as (4) two epilogues. Then author describes theory of three styles applied in the Life and shows figurae verborum, figurae sententiarum and rhetorical devices used in it. Next, the narrative technique is described. Dhugosz used in the Life many metaliterary phrases, e.g. to focus his reader-audience on presented events or to underline his own opinion on the presented subject. He also played with oratio obliqua and oratio recta while describing how Bishop Stanislaus rebuked King Boleslaus. In this part it is also shown in what manner Długosz prepared speeches in oratio recta on the basis of statements contained in the Vita maior by Wincenty of Kielce/Kielcza $\left(13^{\text {th }} \mathrm{c}\right.$.). Subsequently, the author presents rhetorical periods and prose rhythm (cursus) applied in the Life. The second part of the study is devoted to the investigation to what extent Długosz wrote the Life independently from the Vita maior. Author shows that Długosz in his work presented information already described by Wincenty, but in the Life he put them in other places to build tension of the quarrel between the bishop and the king. In his conclusion the author states that Długosz's literary skills were on a high level. Despite the fact that the Life observes the rules set by a literary convention of medieval hagiography. Długosz remained individual: (1) con-

${ }^{271}$ K. Krotoski, Ś. Stanisław biskup, s. 82 n.

272 Ann., ks. 1, s. 59 (list ded.).

273 VSt, s. 83. 
trary to the hagiographic tradition, he placed in the Life four documents in extenso, (2) he also unconventionally put there seven dates, (3) moreover, in his hagiographic work he mentioned political issues motivated by historical arguments. These points are also reasons for the author's argument that Dlugosz wrote all his various works employing the same principles.

Nota o autorze: Hanna Rajfura, mgr, doktorantka w Instytucie Historycznym Uniwersytetu Warszawskiego, laureatka V edycji programu „Diamentowy Grant”, realizuje projekt pt. Pamięć historyczna środowisk kościelnych w Polsce późnego średniowiecza i wczesnej nowożytności. Jana Dlugosza „,Katalog arcybiskupów gnieźnieńskich” i jego kontynuacje na tle europejskim.

Author: Hanna Rajfura, M.A., postgraduate in the Institute of History, University of Warsaw, laureate of the $5^{\text {th }}$ edition of "Diamentowy Grant" [Diamond Grant] programme, she runs the project Pamięc cistoryczna środowisk kościelnych w Polsce późnego średniowiecza i wczesnej nowożytności. Jana Dlugosza "Katalog arcybiskupów gnieźnieńskich" i jego kontynuacje na tle europejskim [Historical memory of Church circles in Poland in the late Middle Ages and Early Modern Age. Jan Długosz's "Catalogue of the Archbishops of Gniezno" and its continuations on the European background].

Instytut Historyczny

Uniwersytet Warszawski

Krakowskie Przedmieście 26/28

00-927 Warszawa

e-mail: hanna.rajfura@student.uw.edu.pl

\section{Bibliografia}

\section{Źródla}

Bibliotheca Hagiographica Latina antiquae et mediae aetatis, t. 1-2, Bruxellis 1898-1901

Długosz J., Annales seu Cronicae incliti Regni Poloniae, t. 1-11, Varsaviae-Cracoviae 1964-2005

Długosz J., Vita sanctissimi Stanislai Cracoviensis episcopi, w: tenże, Opera, t. 1, wyd. I. Polkowski, Ż. Pauli, Cracoviae 1887, s. 1-181

Długosz J., Życie świętego Stanisława biskupa krakowskiego, tłum. S. Bełch, Londyn 1948

Jakub de Voragine, Złota legenda. Wybór, tłum. J. Pleziowa, wybór, wstęp i przyp. M. Plezia, Warszawa 1983

Vita sancti Stanislai Cracoviensis episcopi (Vita maior), wyd. W. Kętrzyński, w: MPH, t. 4, Lwów 1884, s. 319-438

Vita sancti Stanislai episcopi Cracoviensis (Vita minor), wyd. W. Kętrzyński, w: MPH, t. 4, Lwów 1884, s. 238-285

Żywot mniejszy św. Stanisława, w: Średniowieczne żywoty i cuda patronów Polski, thum. J. Pleziowa, oprac. i wstęp M. Plezia, Warszawa 1987, s. 97-150

Żywot większy św. Stanisława, w: Średniowieczne żywoty i cuda patronów Polski, thum. J. Pleziowa, oprac. i wstęp M. Plezia, Warszawa 1987, s. 235-344

\section{Opracowania}

Bering P., Struktury narracyjne w późnośredniowiecznych łacińskich kronikach regionalnych, Gniezno 2001

Borkowska U., Historiograficzne poglady Jana Dlugosza, w: Dlugossiana. Studia historyczne w pięćsetlecie śmierci Jana Dlugosza, cz. 2: Referaty i komunikaty wygłoszone na międzynarodowej sesji w Krakowie $w$ dniach 23 i 24 października 1980 r., red. S. Gawęda, Kraków 1985, s. 45-71

Borkowska U., Treści ideowe w dziełach Jana Dlugosza. Kościót i świat poza Kościołem, Lublin 1983

Gieysztor A., Ze studiów nad geneza wypraw krzyżowych. Encyklika Sergiusza IV (1009-1012), Warszawa 1948 Janson T., Latin Prose Prefaces. Studies in Literary Conventions, Stockholm-Göteborg-Uppsala 1964

Janson T., Prose Rhythm in Medieval Latin from the $9^{\text {th }}$ to the $13^{\text {th }}$ Century, Lund 1975

Lausberg H., Retoryka literacka. Podstawy wiedzy o literaturze, tłum., oprac. i wstęp A. Gorzkowski, Bydgoszcz 2002

Markowski M., Tendencje rozwojowe piętnastowiecznej retoryki krakowskiej, w: Retoryka w XV stuleciu. Studia nad tradycjami, teoria i praktyka retoryki piętnastowiecznej, red. M. Frankowska-Terlecka, Wrocław 1988, s. $87-119$ 
Michałowska T., Średniowieczna teoria literatury w Polsce. Rekonesans, Wrocław 2007

Nehring P., Topika wczesnych łacińskich żywotów świętych (od „Vita Antonii” do „Vita Augustini”), Toruń 1999 Plezia M., Dookoła sprawy św. Stanisława. Studium źródłoznawcze, „Analecta Cracoviensia”, 11, 1979, s. 251-413

Plezia M., Kronika Galla na tle historiografii XII wieku, Kraków 1947

Plezia M., Retoryka mistrza Wincentego, St. Źródł., 20, 1976, s. 88-94

Plezia M., Transmundus, w: Kultura średniowieczna i staropolska. Studia ofiarowane Aleksandrowi Gieysztorowi w pięćdziesięciolecie pracy naukowej, red. D. Gawinowa i in., Warszawa 1991, s. 163-169

Rzepiela M., Jeszcze o miejscu dziejów legendarnych w polskiej historiografii średniowiecznej: Gall Anonim, Kadtubek, Dlugosz, w: Jan Długosz - w kręgu badań historyków i literaturoznawców, red. T. Giergiel, Sandomierz 2017, s. 45-59

Rzepiela M., Rola frazeologii w narracji „Kroniki” Jana Długosza, w: Jan Dtugosz (1415-1480). Życie i dzieła, red. L. Korczak, M.D. Kowalski, P. Węcowski, Kraków 2016, s. 237-243

Stownik literatury staropolskiej: średniowiecze, renesans, barok, red. T. Michałowska, przy udziale B. Otwinowskiej, E. Sarnowskiej-Temeriusz, Wrocław 2002

Turkowska D., Etudes sur la langue et sur le style de Jean Długosz, Kraków1973

Werpachowska A., Z dziejów retoryki XVI wieku. Polemika Jakuba Górskiego z Benedyktem Herbestem, Wrocław 1987

Ziomek J., Retoryka opisowa, Wrocław 1990 